CLELIA FERREIRA

\title{
ASPECTOS ULTRAESTRUTURAIS E ENZIMÁTICOS DO PROCESSO DIGESTIVO E CARACTERIZAÇÃO FISICA E CINÉTICA DA CELOBIASE INTESTINAL DE
}

Rhynchosciara americana

Tese de Doutoramento apresentada ao Departamento de Bioquímica do Instituto de Química da Universidade de São Paulo 
A realizacão deste trabatho só foi possivel devido a colaboragão de algumas instituigões e de värias pessoas. A to das elas gostaria de transmitir um pouco do muito que thes sou grata.

Inicialmente, ao Dr. Walter $R$. Terra, que sempre soube transmitir seu entusiasmo pela pesquisa cientifica, por sua cons tante orientasão, confiansa e apoio.

Ao Dr. Alberto de Freitas Ribeiro do Instituto de Biociências, colaborador inestimävel da parte morfolögica deste tra balho, pela grande amizade.

A amiga Luiza Y. Nakabayashi, pelo eficiente auxilio prestado na parte experimental desta tese e também pela sua dedí cąão na manutencão dos aparelhos e da ordem no laboratório.

Aos membros do Instituto de Biociências Mărcio V. Cruz, Marli Garrido e J.A. Bilotta pelo excelente trabalho técnico pres tado.

Aos companheiros de Zaboratörio, Dr. Antonio G. de Bian chi, Custödio D. Santos, Fernando Espinoza, Fernando Bastos, osvaldo Marinotti e Sirley $D$. Pereira, pela amizade.

A Ana Maria Rocha e ao Sr. João Rocha pelo cuidado cons tante na manutencão dos animais e pelo auxilio técnico prestado.

A todos os amigos deste Instituto que durante todos es ses anos coloboraram comigo apoiando-me e incentivando-me.

A Vera Lucia Romera, responsável pela eficiente datilo grafia desta tese.

A Fundąão de Amparo à Pesquisa do Estado de são Paulo (EAPESP) pelos auxilios financeiros que possibilitaram a realiza são deste trabalho. 


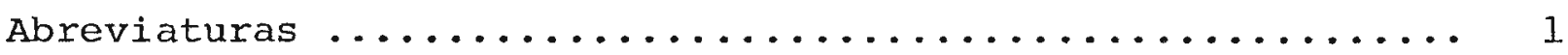

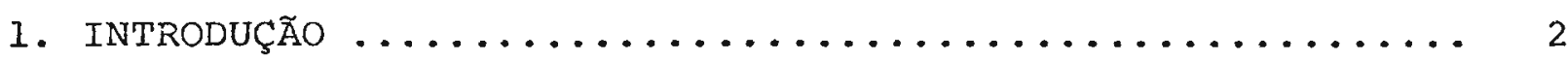

1.1. Considerações iniciais .................. 2

1.2. Hidrolases intestinais de oligômeros em mamiferos .. 3

1.3. Anatomia do tubo digestivo de Rhynchosciara americana .. 5

1.4. Hidrolases envolvidas na digestão em insetos ...... 8

1.5. Organização espacial do processo digestivo nos

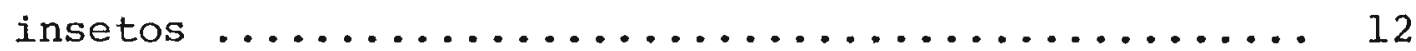

1.6. Objetivos desse trabalho ................. 16

2. MATERTAL E METODOS .............................. 18

2.1. Materiais ......................... 18

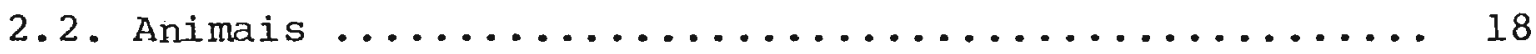

2.3. Obtenção de fluído luminal dos cecos e células dos cecos gástricos e do ventrículo ............ 18

2.4. Microscopia óptica e eletrônica ................ 19

2.5. Preparação de microvilosidades de diferentes regiões do intestino médio .................. 20

2.6. Fracionamento celular de células dos cecos gās

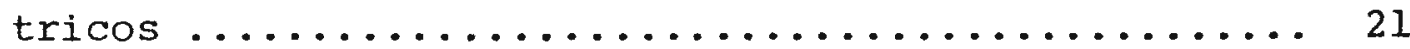

2.7. Preparação das membranas dos cecos gãstricos e sua solubilização por Triton $x-100 \ldots \ldots \ldots \ldots \ldots$

2.8. Solubilização de hidrolases da membrana dos ce cos por papaina ......................

2.9. Determinação do peso molecular por centrifuga-

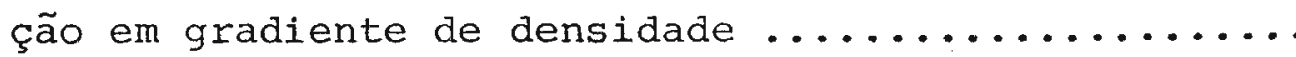

2.10. Eletroforese e determinação de atividades enżí

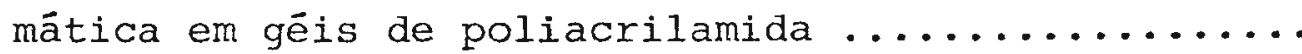

2:11. Eletrofocalização e determinação de atividades

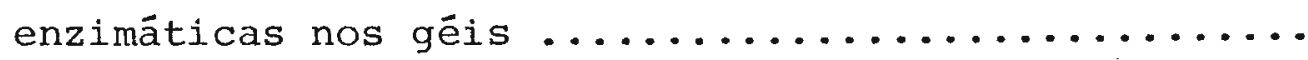


Pág.

2.12. Determinação de atividades enzimáticas e de pro-

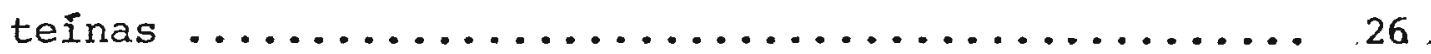

2.13. Inibição da hidrólise de celobiose por pNPBGli e inibição da hidrólise de pNPBGli por celobio

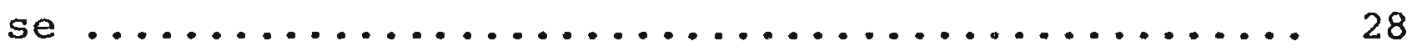

2.14. Identificação da configuração da glicose liberada pela celobiase solubilizada em papaína ...... 29

3. RESULTADOS ............................... 31

3.1. Atividade de arilamidases nas frações subcelula res e conteúdo luminal dos cecos gástricos ........ 31

3.2. Eletroforese de arilamidases presentes no citos sol e lümen dos cecos gástricos .............. 35

3.3. Histologia do intestino médio de R.americana ...... 38

3.4. Ultraestrutura das células dos cecos gástricos ..... 40

3.5. Ultraestrutura das células do ventrículo ........ 42

3.6. Enzimas de microvilosidades de diferentes re giões do tubo digestivo ................. 47

3.7. Solubilização da celobiase por detergente e por papaina .......................... 52

3.8. Peso molecular e pI da celobiase solubilizada por detergente e por papaína ................ 52

3.9. Inativação térmica da celobiase solubilizada por detergente e por papaína ............... 56

3.10. Efeito do $\mathrm{pH}$ e da temperatura na celobiase so lubilizada por papaína .................. 58

3.11. Especificidade de substrato da celobiase puri ficada $\ldots \ldots \ldots \ldots \ldots \ldots \ldots \ldots \ldots \ldots \ldots \ldots \ldots \ldots \ldots$

3.12. Inibição da celobiase solubilizada com papaína por Tris e lactonas ..................... 66 
Pāg.

3.13. Configuração anomérica da D-glicose liberada pela celobiase solubilizada por papaína .......... 66

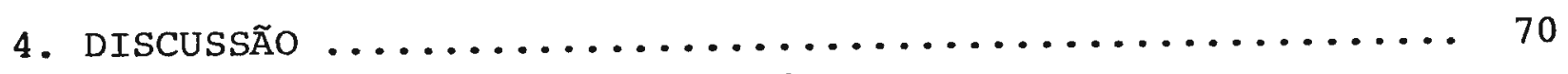

4.1. O papel das arilamidases dos cecos de R.americana ... 70

4.2. As células dos cecos gāstricos de R.americana ...... 71

4.3. As células do ventrículo anterior e posterior

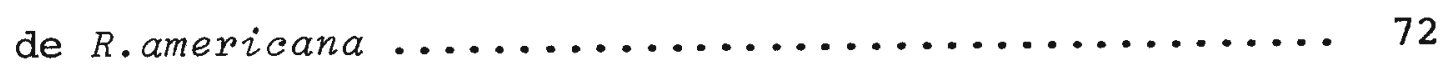

4.4. Função dos cecos é do ventrículo em $R$.americana..... 73

4.5. A função dos cecos do intestino médio e de estruturas semelhantes nos insetos ............ 78

4.6. Aspectos físico-químicos da celobiase de $R$. americana ............................ 82

4.7. Especificidade, inibição e mecanismo da celo biase de $R$.americana ..................... 83

5. $\operatorname{RESUMO} \ldots \ldots \ldots \ldots \ldots \ldots \ldots \ldots \ldots \ldots \ldots \ldots \ldots \ldots \ldots \ldots \ldots$

6. ABSTRACT .............................. 90

7. REFERENCIAS BIBLIOGRAFICAS $\ldots \ldots \ldots \ldots \ldots \ldots \ldots \ldots \ldots \ldots$ 


\section{ABREVIATURAS}

$$
\begin{aligned}
& \text { ArgßNa, L-arginina-B-naftilamida } \\
& \text { EDTA, etilenodiaminotetraacetato de sódio } \\
& \text { LeußNa, L-leucina- } \beta \text {-naftilamida } \\
& \text { LPNA, L-leucina p-nitroanilida } \\
& \text { Met } \beta \mathrm{Na}, \quad \text { DL-metionina- } \beta \text {-naftilamida } \\
& \text { NPBFuc, } \quad \text {-nitrofenil- } \beta-D \text {-fucosídeo } \\
& \text { NPBGal, } \quad \text {-nitrofenil-B-D-galactosídeo } \\
& \text { NPaGli, } \quad p \text {-nitrofenil- } \alpha-D-g l i \cos i ́ d e o \\
& \text { oNPBGli, o-nitrofenil-B-D-glicosideo } \\
& \text { pNPBGli, p-nitrofenil-B-D-glicosideo } \\
& \text { NPP, } \quad \text {-nitrofenil fosfato } \\
& \text { PBGli, fenil- } \beta-D-g l i c o s i d e o \\
& \text { Phe-GlY, L-fenilalanil-glicina } \\
& \text { PHMB, p-hidroximercuriobenzoato } \\
& \text { ProßNA, L-prolina-B-naftilamida } \\
& \text { SDS, dodedil sulfato de sódio } \\
& \text { TLCK, N- N-p-tosil-L-lisina clorometilcetona } \\
& \text { Tris, tris-(hidroximetil) amino metano } \\
& \text { Z-Gly-Leu, carbobenzoxiglicil-L-leucina } \\
& \text { Z-Gly-Phe, carbobenzoxiglicil-L-fenilalanina } \\
& \text { z-Val-Leu, carbobenzoxivalil-L-leucina }
\end{aligned}
$$




\section{INTRODUÇ $\widetilde{A} O$}

\subsection{Considerações iniciais}

Digestão é a sequência de modificações que o alimento ingerido sofre até ser transformado em molēculas simples que podem ser utilizadas pelo organismo.

A digestão de polímeros, tais como polissacarídeos e proteínas, que correspondem a maior massa do alimento usualmente consumido pelos animais, pode ser dividida em três fases distintas. A primẹira fase, a digestão primäria, consiste no ataque às ligações internas dos polímeros por enzimas secretadas resultando nos oligômeros correspondentes. Estes são hidrolisados durante a digestão intermediária, tendo seu tamanho molecular reduzido por ação das mesmas enzimas envolvidas na primeira fase e/ou enzimas diferentes, geralmente tambëm secretadas. Por fim, ocorre a digestão terminal através da qual os oligômeros (mais frequentemente dímeros e trímeros) são hidrolisados até monômeros, monossacarídeos e aminoācidos, que podem ser absorvidos e utilizados no metabolismo celular.

As enzimas hidrolíticas envolvidas na digestão primária e intermediāria são usualmente secretadas por células presentes na parede do trato digestivo ou por glândulas, como o hepatopân creas dos crustáceos e moluscos e o pâncreas dos vertebrados. A saliva em alguns animais contēm enzimas importantes na digestão, embora em grande número de organismos sua função seja apenas a de lubrificar o alimento (BARNARD, 1973).

A digestão terminal nos mamíferos é realizada por enzimas hidrolíticas presentes na membrana plasmática que recobre as microvilosidades das células intestinais (cf. KENNY \& BOOTH, 1978 ; ver também İtem 1.2.). Em vista desses resultados, tem sido proposto que na maioria dos organismos a digestão terminal seja rea- 
lizada em membranas celulares (por exemplo UGOIEV \& DE LAEY,1973), embora sejam necessários muito mais estudos para assegurara generalidade da proposição.

A preocupação principal desta tese é em relação a diges tão intermediāria e final, isto é, em relação a sequência de processos pelo qual os oligômeros são hidrolisados até monômeros. Por outro lado, as hidrolases envolvidas em digestão terminal são de longe melhor conhecidas em mamíferos. Em vista disso, e levando em conta que muitas técnicas para o estudo das enzimas envolvidas na digestão terminal foram, e continuam sendo, desenvolvidas em mamíferos, iniciaremos a revisão enfocando primeiro as hidrolases de membrana de mamíferos e a seguir os processos digestivos dos insetos.

1.2. Hidrolases intestinais de oligômeros em mamíferos

A hidrólise terminal dos oligopeptídeos ocorre sob a ação de aminopeptidases e dipeptidases que apresentam uma certa variedade interespecifica. Entretanto, de regra, existem amino peptidases integrantes da membrana das microvilosidades dos enterocitos responsáveis pela hidrólise de oligopeptídeos de três ou mais resíduos de aminoácidos e aminopeptidases e dipeptidases de citossol com atividade sobre tri- e dipeptídeos (p. ex., rato: vi de KIM et al., 1974; homem: vide STERCHI \& WOODLEY, 1980).

As aminopeptidases ligadas a membranas de microvilosida des foram purificadas a partir de enterocitos de porco (MAROUX et. al., 1973; BENAJIBA \& MAROUX, 1980), rato (KIM \& BROPHY, 1976) e coelho (GORVEL et al., 1980; FERACCI \& MAROUX, 1980). Os resulta dos, que envolveram a solubilização da enzima em detergentes e/ou sua remoção por tratamento com proteases, mostram a existência de uma aminopeptidase (aminopeptidade $N$ ) mais ativa sobre peptídeos 
neutros e substratos sintēticos e outra (aminopeptidase A) mais ativa sobre derivados de aminoācidos ācidos.

A aminopeptidase $\mathrm{N}$ de intestino de porco é uma proteína transmembrana, composta de uma "cabeça" enzimaticamente ativa, hidrofílica, rica em carboidratos e que se salienta a partir da face externa da membrana e de uma âncora predominantemente hidrofóbica atravessando todo o cerne lipídico da membrana (MAROUX \& LOU VARD, 1976; DESNUELLE, 1979). Como várias outras enzimas de membrana, a molécula de aminopeptidase pode ser extraída inteira com detergentes neutros, originando uma forma anfipātica chamada de forma pós-detergente. A enzima pode ser também removida da mem brana por clivagem proteolítica na junção hidrofílica-hidrofóbica da cadeia proteíca. A forma resultante (forma pós-protease) corresponde grosseiramente à cabeça hidrofiliica da enzima (MAROUX \& LOUVARD, 1976; DESNUELLE， 1979).

As peptídeo hidrolases de citossol de enterocitos de ma míferos estão representadas por duas dipeptidases e por uma amino tripeptidase. Uma das dipeptidases atua na maioria dos dipeptí deos com poucas exceções, entre os quais estão os aminoacil-proli na que são hidrolisados pela outra dipeptidase (prolina dipeptida se) (cf. NOREN et al., 1973; SJOSTROMM et al., 1973). A aminotripeptidase é uma aminopeptidase que atua sobre tripeptídeos e que apresenta uma especificidade ampla em relação ao resíduo do terminal N (DOUMENG \& MAROUX, 1979).

A digestão terminal dos carboidratos em mamíferos ocor re inteiramente sob ação de enzimas presentes na membrana das microvilosidades dos enterocitos. Os monossacarídeos resultantes da hidrólise são transportados por carregadores, que, em alguns casos, parecem agir em intima cooperação com ashidrolases, pois observa-se que a absorção de açūcares recém clivados é mais rápi da que se os mesmos produtos forem adicionados ao lúmen intesti- 
nal (CRANE, 1968; BARNARD, 1973).

A dissacaridase de membrana melhor estudada até o presente é a sacarase-isomaltase. Essa enzima apresenta duas subuni dades de peso molecular semelhante (120.000 e 140.000), uma contendo o sîtio de clivagem de isomaltose e a outra o sítio de clivagem de sacarose. Somente a subunidade que apresenta atividade de isomaltase possui um segmento ancorador hidrofóbico (BRUNNER et al., 1979). Estudos mais recentes mostraram que quando essa enzima não é exposta a enzimas pancreáticas, a proteína isolada apresenta uma só cadeia (SJÖSTRÖM et al., 1980). Essa prō-sacara se-isomaltase foi recentemente sintetizada em sistema livre de cẹ lulas, após isolamento de seu RNAm (WACKER et al., 1981).

Foram também caracterizadas as subunidades da lactaseflorizina hidrolase. Essa proteína possui duas subunidades de mesmo peso molecular $(160.000)$ e aparentemente cada uma delas possui um segmento anoorador hidrofóbico. Uma das cadeias hidroli sa florizina e a outra é responsável pela hidrólise de lactose. E interessante notar que o mesmo sítio que hidrolisa lactose cata Iisa a clivagem de celobiose (SKOVBJERG et al., 1981).

\subsection{Anatomia do tubo digestivo de Rhynchosciara americana*}

Antes de comentarmos o processo digestivo dos insetos, seria conveniente descrever sumariamente a anatomia de seus tubos digestivos, o que faremos a seguir, utilizando a larva de Rhynchosciara americana como exemplo.

* Rhynchosciara americana - WIEDEMANN, 1821 (Diptera Nematocera Sciaridae), foi redescrita por NONATO \& PAVAN (1821) como angeZae e essa denominação foi usada em numerosas publicações até ser demonstrada sua sinonímia como americana por BREUER (1969). 
o canal alimentar é um tubo de comprimento e grau de complexidade variável conforme o grupo taxonômico e a fase de desenvolvimento do inseto.

A larva de $R$. americana apresenta um tubo digestivo bastante simples, sem grandes dobramentos e com diâmetro que varia pouco em toda a sua extensão. E dividido em 3 regiões: anterior, mëdia e posterior (Fig.1.). A região anterior é formada pela cavidade bucal, faringe e esôfago. Este termina na vālvula cardíaca e não apresenta dilatação para formar um papo, como ocorre em muitos insetos. A porção mais longa do canal alimentar é a região média , composta pelo ventrículo e por dois longos cecos que se abrem jun to à válvula cardíaca. o ventrículo termina no ponto de abertura dos tubos de Malpighi, onde inicia-se a região posterior que apre senta uma única dobra e abre-se diretamente no ânus. As células da região anterior e posterior do tubo digestivo são cobertas por uma cutícula, o que não ocome na região média (MARQUES, 1976). O ali mento é separado do epitélio ventricular por uma membrana tubular, a membrana peritrófica. Em R. americana esta membrana é sintetiza da na junção entre a região anterior e o ventrículo, resultando em um tubo contínuo que não penetra nos cecos e envolve o bolo alimentar ao longo de todo o ventrículo até o intestino posterior onde se desfaz por ação de denticulos da cutícula (MARQUES, 1976).

A existência dessa membrana delimita dois compartimen tos luminais distintos: o espaço endoperitrófico, que corresponde a região interior à membrana peritrófica, onde está presente o alimento e o espaço ectoperitrófico, que é formado pelo lúmen dos cecos e pela região entre as células do ventrículo e a membrana peritrófica (Fig.1).

o espaço ectoperitrófico apresenta proporçộes variadas em diferentes insetos, podendo atingir volume considerável e igua lar aquele do espaço endoperitrōfico (RICHARDS \& RICHARLS, 1977). 


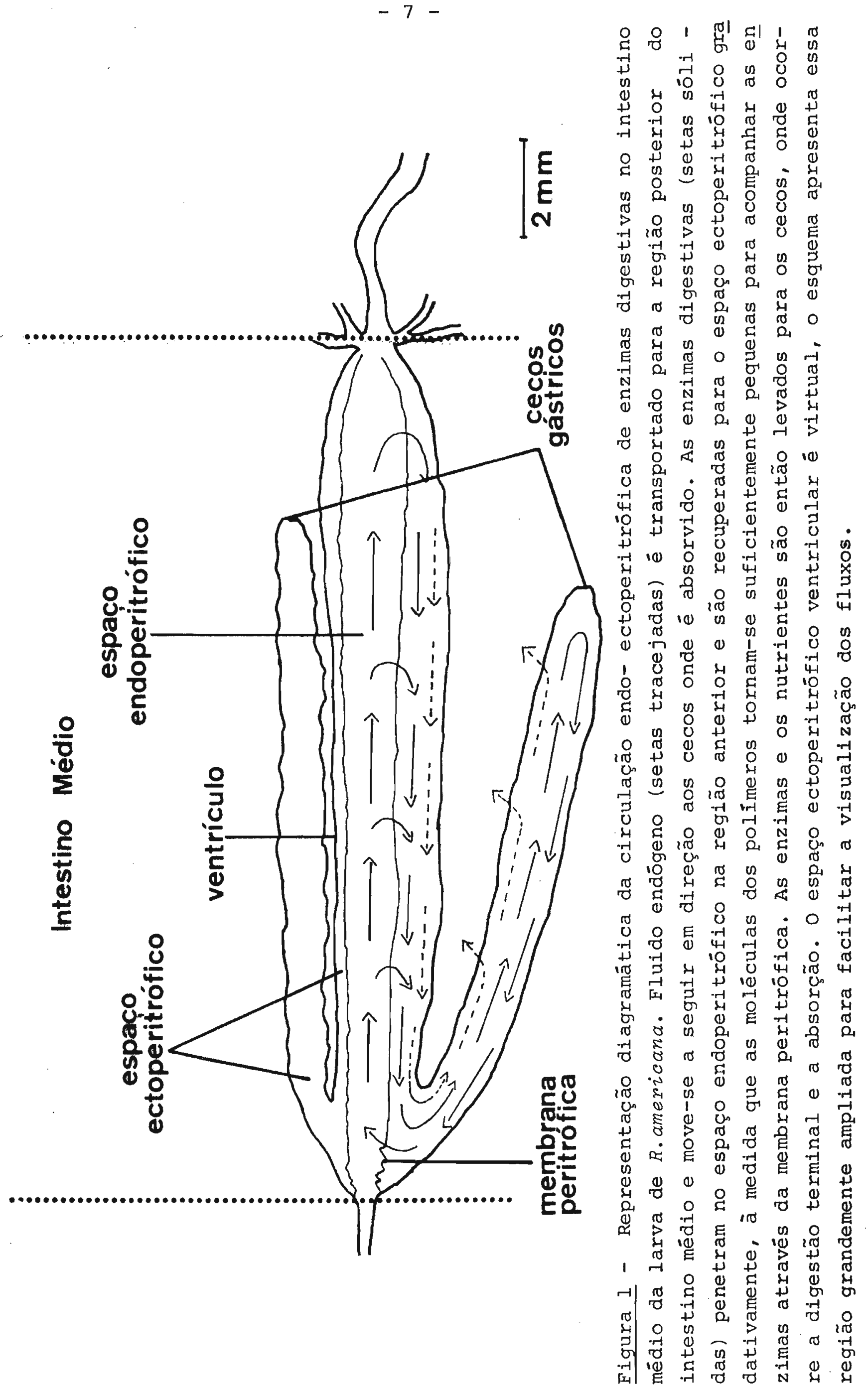


Em R.americana o diâmetro da membrana peritrófica é maior que o do Iúmen ventricular, formando-se numerosas dobras (MARQUES, 1976). Desse modo, o espaço ectoperitrófico nesse animal é constituído majoritariamente pelo lúmen dos cecos e, em menor escala, por pequenos bolsões formados entre o epitélio do ven trículo e as pregas da membrana peritrófica.

\subsection{Hidrolases envolvidas na digestão em insetos}

A digestão dos insetos pode ser encarada sob dois aspec tos principais. O primeiro se refere à organização espacial do processo digestivo, isto é, a descrição da sequência de processos pelos quais o alimento passa nas diferentes regiões do tubo diges tivo, desde a sua ingestão até a sua absorção. o segundo aspecto consiste na descrição física e cinética das hidrolases envolvi das na digestão. Esse último aspecto é o mais conhecido e será. revisto primeiro.

o alimento consumido pelos insetos, assim como dos demais animais, é composto primordialmente por carboidratos, proteí. nas e lipídeos. As enzimas envolvidas na digestão de lipídeos por insetos foram revistas recentemente (TURUNEN, 1979) e não mais se rão comentados aqụi.

A maioria das proteinases digestivas descritas em insetos são ativas em pHs alcalinos ou neutros e são do tipo serina proteinase com especificidades similares aquelas da tripsina ou quimotripsina de mamíferos (revisão em LAW et al., 1977). Entretanto, poucas dessas enzimas foram purificadas até a homogeneidade, como por exemplo a tripsina presente no tubo digestivo de Manduca sexta (MILLER et al., 1974) e a quimotripsina de Vespa orientalis (JANY et al., 1974). Existem descritas e purificadas além de serina proteinases, sulfidril proteinases ( em Rhodnius 
prolixus, GARCIA et al., 1978) e metaloproteinases (em Tineola bisselziela, WARD, 1975a, e).

As aminopeptidases de insetos tem sido pouco estudadas (LAW et al., 1977). O estudo mais completo existente foi realiza do em tubo digestivo de Tineola bisselliella, onde foram detectadas 16 aminopeptidases solúveis, das quais 9 foram caracterizadas (WARD, 1975a,b,c). Essas aminopeptidases são capazes de hidrolisar di, tri e oligopeptídeos sequencialmente a partir da extremidade $\mathrm{N}$-terminal, possuem pequena especificidade e foram consideradas em dois grupos de acordo com a sua migração eletroforética. A principal diferença entre os dois tipos é o peso molecular (240.000 para as aminopeptidases de migração menor e 94.000 para as de migração maior) e a capacidade de hidrolisar ligações envolvendo prolina, característica das aminopeptidases de migração maior (WARD, $1975 b$ e c). Outras aminopeptidases solúveis purificadas e parcialmente caracterizadas foram as de Glossina morsitans (GOODING \& ROLSETH, 1976) e de Attagenus megatoma (BAKER \& WOO, 1981).

As carboxipeptidases intestinais foram melhor estudadas nas frações solúveis de Tineola bissezzielza, onde foram encontra das duas carboxipeptidases sulfidrílicas com preferência para ZGly-Leu (WARD, 1976) e de Attagenus megatoma, que possui duas carboxipeptidases, uma semelhante à carboxipeptidase A e outra com preferência para Z-Val-Leu (BAKER, 1981).

As amilases que se encontram nos insetos são do tipo $\alpha$-amilase (revisão em DADD, 1970). Existem duas amilases purifi cadas até a homogeneidade: a amilase de C.chinensis (PODOLER \& APPLEBAUM, 1971) e a de Tenebrio molitor (BUONOCORE et al.,1976). o padrão de ação da a-amilase de insetos é (pelo menos no único caso em que este foi estudado, cf. TERRA et al., 1977) similar ao da $\alpha$-amilase salivar humana. 
digestivos (ou de seus anexos) em vārias ordens de insetos: CoZeoptera (WIGGLESWORTH, 1972), Thysanura (LASKER \& GIESE, 1956) , Diatyoptera (WHARTON et al., 1965), Orthoptera (Morgan, 1976),Dip tera (TERRA et al., 1979). Entretanto, até o presente, nenhuma cạ cacterização das celulases foi tentada em insetos.

As glicosidases usualmente encontradas no tubo digesti vo de insetos são: $\alpha$-e $\beta$-glicosidases, $\alpha$-e $\beta$-galactosidases, trealases e raramente $\beta$-frutosidases (DADD, 1970 ; CRIPPENDALE, 1978). Com exceção das trealases (que serão comentadas mais abai xo), a maioria das glicosidases foi estudada de maneira superficial, frequentemente não passando da demonstração de que substratos selecionados são hidrolisados por homogeneizados crus do tubo digestivo e as enzimas sendo designadas de acordo com seu substra to (DADD, 1970; HOUSE, 1974). O que torna ainda mais difícil a interpretação dos dados encontrados é o fato de que grande número deles foi obtido utilizando-se apenas substratos sintéticos, quan do se sabe que existem glicosidases que clivam substratos natu-i rais, mas não os arilglicosídeos correspondentes e vice-versa(MORGAN, $1975 \mathrm{a}, \mathrm{c})$.

As sacarases de j.nsetos estudadas em detalhe foram, com uma única exceção, apenas as obtidas a partir de animais inteiros. Assim MARZLUF (1969) mostrou a existência em Drosophita melanogas tex de sacarases ligadas a membrana e solúveis, sendo que estas últimas ocorrem como uma família de isoenzimas. Mais tarde HUBER \& LEFEBVRE (1971) purificaram uma das sacarases solúveis de D.Melanogaster e mostraram que ela tinha um peso molecular de cerca de 3.00.000 e era fortemente inibida por PHMB e Tris. Mais recentemente duas sacarases solúveis de Apis mellifera foram purificadas até a homogeneidade e caracterizadas física e cineticamente (HUBER \& THOMPSON, 1973 ; HUBER, 1975; HUBER \& MATHISON, 1976). Ambas as sacarases solúveis de A.mellifera são $\alpha$-glicosidases ines 
pecíficas, pouco sensíveis a reagentes sulfidrilas, apresentam atividade de transglicosilação e como ocorrem principalmente no abdômen de A.mellifera (HUBER, 1975; HUBER \& MATHISON, 1976), é razoável supor que elas se encontrem no tubo digestivo. Periplaneta americana é o único inseto que teve a sua sacarase intestinal parcialmente purificada. A enzima é solüvel e corresponde a uma $\alpha$-glicosidase inespecífica, embora a preparação pareça estar contaminada por outras glicosidases (KATAGIRI, 1979).

Muito poucas $\beta$-glicosidases (revisão em MORGAN, 1975a) e B-galactosidases (revisão em MORCiAN, 1975b) de insetos em geral, e de seu, tubo digestivo em particular, foram caracterizadas, mesmo ao nível apenas da determinação de seu pHōtimo e $\mathrm{Km}$. O es tudo mais completo dessas enzimas em tubos digesticos de insetos foi realizado em L.migratória. Nesse inseto MORGAN (1975c) usan do filtração em gel, desnaturação térmica e focalização isoelétri ca mostrou que apenas uma espécie molecular (PM 110.000) é respon sāvel pela hidrólise de celobiose e lactose, enquanto que as ati-

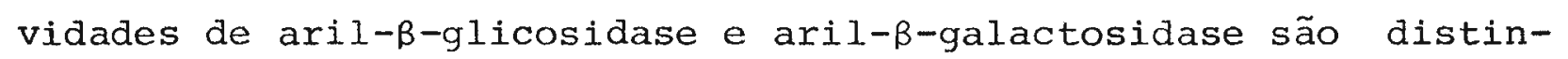
tas entre si e da enzima que cliva celobiose e lactose. Todas as enzimas referidas são solūveis.

Trealase (EC 3.2.1.28) è uma das carboidrases de insetos com distribuição mais ampla, ocorrendo principalmente no intestino médio, músculo do vôo, corpo gơrduroso e glândulas labiais (WYATT, 1967). Algumas trealases solúveis foram altamente purifi cadas a partir de insetos inteiros (KALF \& RIEDER, 1958; FRIEDMAN; 1960; SAITO, 1960; DERR \& RANDALL, 1966; GUILLOUX et al., 1968 ; HUBER \& LEFEBVRE, 1971; DAHLMAM ., 1971; GIEBEL \& DOMNAS, 1976) . Entretanto, Rhynchosciara americana é dos poucos insetos cuja trea lase intestinal foi parcialmente purificada e caracterizada. Os resultados sugerem que se trata de uma enzima solúvel, com um peso molecular de 122.000, apresentando em seu sítio ativo duas car 
boxilas envolvidas no processo de catálise (TERRA et al., 1978).

\subsection{Organização espacial do processo digestivo nos insetos}

A organização do processo digestivo nos insetos é pouco conhecida porque, embora existam muitos estudos sobre enzimas digestivas em insetos, são raros os que estudam a distribuição des sas enzimas no canal alimentar (revisões em DADD, 1970; WIGGLES WORTH, 1972; HOUSE, 1974; LAW et al., 1977; CHIPPENDALE, 1978) . Desse modo, os passos pelos quais o alimento ingerido é hidrolisa do nos diferentes sitios do tubo digestivo é praticamente desco nhecido. Isto é uma consequência das dificuldades em se coletar amostras de enzimas dos diferentes sitios do tubo digestivo de insetos, e também pelo não estabelecimento pelos diferentes autores de critérios para distinguir enzimas secretadas daquelas presentes nos espaços luminais devido a descamação e/ou rompimento celular durante a dissecção, e para separar enzimas que penetram daquelas que apenas se adsorvem na membrana peritrófica. Além disso, nenhum trabalho, com exceção do realizado em $R$. americana (ver abaixo), analisa a distribuição de enzimas entre o espaço en do e o ectoperitrófico. Isto dificulta sobremaneira a compreenção do processo digestivo naqueles insetos. Entretanto, apesar disso, algumas generalizações podem ser feitas.

Nos Orthoptera (pelo menos na família Acrididae) a digestão de carboidratos é principalmente luminal. Parte dessas en zimas devem ser providas pelas glāndulas salivares, embora um cer to nümero seja exclusivamente secretado pelo intestino (Celobiase, aril-a-galactosidase, lactase, cf. KHAN, 1962; EVANS \& PAYNE,1964; FREEMAN, 1967; DROSTE \& ZEBE, 1974). Como não existe informação sobre a distribuição das enzimas Iuminais entre os espaços ecto e endoperitrófico, não se pode saber se nestes insetos a maior 
parte da digestão intermediária e final ocorre nos espaços ectope ritróficos ou não. Por outro lado, a digestão de carboidratos ao nível da membrana plasmātica das microvilosidades das células intes tinais dos Orthoptera deve ser insignificante, se existir. Essa conclusão segue-se da observação de que a maior parte das carboidrases celulares em L.migratoria é solúvel (DROSTE \& ZEBE, 1974). Os resultados são muito fragmentärios para se tirar conclusões so bre a digestão terminal de proteỉnas em orthoptera.

Os Coleoptera, exemplificados pelo besouro Leptinotarsa decemlineata, apresentam algumas semelhanças com os Orthoptera, desde que possuem algumas carboidrases secretadas pelo intestino (cf. FINK, 1932).

A formiga cortadora de folhas Atta colombica tonsipes, embora apresente um amplo espectro de carboidrases no espaço endo peritrófico (coletado como fluido fecal), não possui na verdade nenhuma enzima digestiva própria. Existe evidência segura de que as enzimas digestivas das formigas do gênero Atta são derivadas dos fungos que elas cultivam (BOYD \& MARTIN, 1975). Aliás, a aquisição de enzimas digestivas de fontes externas, com a finalida de de expandir a gama de substratos naturais capazes de servirem como fonte nutritiva, parece não ser muito raro, sendo observado também entre os Isoptera. Nesta ordem, as térmites superioreslfa milia Termitidae) adquirem as celulases $-C_{1}$ criticas para iniciarem a digestão de celulóse a partir de suas culturas de fungos (MARTIN \& MARTIN, 1978, 1979).

Os Diptera, além de $R$.americana (ver abaixo), foram mị to pouco estudados e só se podem fazer considerações em relação à digestão terminal de proteínas. E interessante notar que Glossina morsitans possui uma grande quantidade de uma aminopeptidase so lüvel de peso molecular superior a 100.000 e que não é encontrada no espaço endoperitrófico (GOODING \& ROLSETH, 1976). E razoável 
supor que esta aminopeptidase ocorra, além das células intestinais, também no espaço ectoperitrófico e que não penetre no espa ço endoperitrófico, como ocorre em R. americana (cf. TERRA et al., 1979), devido ao seu elevado peso molecular. Em relação às carbo xipeptidases parecem ocorrer diferenças reais entre os dois Dipte ra. Enquanto em G.morsitans, as carboxipeptidase A e B, com pesos moleculares respectivamente de 30.200 e 22.000 , são encontra dos no espaço endoperitrófico, as carboxipeptidases de R.americana não o são (TERRA et al., 1979).

Os dados discutidos permitem supor que a digestão inter mediāria e final nos insetos deve ocorrer de forma distinta nas diferentes ordens de insetos. Mesmo dentro de uma ordem devem ocorrer adaptações típicas de alguns gêneros, como parece ser o ca so do gêneto Atta entre os Hymenoptera e das térmites superiores entre os Isoptera.

A larva de R.americana, tanto quanto sabemos, é o inseto cuja organização do processo digestivo é melhor conhecida. Pạ ra isso, um grande número de enzimas foram ensaiadas em diferentes segmentos do tubo digestivo e critérios foram desenvolvidos pạ ra determinar o sitio de ocorrência das enzimas (Terra et al. , 1979).

Os resultados mostraram que toda a digestão ocorre no intestino médio e que as enzimas aî encontradas apresentam três tipos de distribuição: a) enzimas secretadas para o lúmen do intestino médio que penetram na membrana peritrófica (proteinase, celulase e $\alpha$-amilase); b) enzimas secretadas para o lúmen do intestino médio, mas que não penetram na membrana peritrófica, permanecendo no fluido ectoperitrófico (trealase e aminopeptidase) ; c) enzimas restritas às células (entre elas celobiase, maltase, B-galactosidase, dipeptidase, carboxipeptidase e fosfatase alcali na). Entre as enzimas secretadas, a única que apresentava grande 
atividade nas células do intestino médio (cerca de $50 \%$ da ativida de do intestino médio total) era a aminopeptidase. Esses resulta dos permitiram propor a existência de três fases espacialmente or ganizadas no processo digestivo desse inseto. A primeira, ocor rendo no interior da membrana peritrófica, consistiria no ataque a polímeros resultando em oligômeros que difundir-se-iam para os espaços ectoperitróficos onde se daria a segunda fase da diges tão, na qual esses oligômeros seriam degradados à moléculas meno res. A terceira fase, correspondente à digestão terminal, ocorreria nas células do epitélio ventricular posterior e, principalemente, dos cecos.

Afim de determinar o sitio celular de ocorrência $\therefore$ das hidrolases envolvidas em digestão terminal, que ocorrem principal mente nos cecos gāstricos, esse tecido de R.americana foi submeti do a centrifugação diferencial após homogeneização branda e vigorosa, assim como a técnicas que levam a purificação de microvilosidades celulares. Os resultados permitiram propor que a diges tão terminal de proteínas ocorre na membrana plasmática (e talvez também no citossol) das células dos cecos, principalmente pela ação de aminopeptidases, enquanto que a digestão de carboidratos, com exceção da: trealose, ocorre somente na superfície das microví Iosidades (FERREIRA \& TERRA, 1980).

As velocidades de excreção das enzimas que penetram no espaço endoperitrófico de $R$. americana são muito baixas, sugerindo a existência de algum mecanismo pelo qual essas enzimas são recuperadas do alimento não digerido, antes de serem excretadas (TERRA \& FERREIRA, 1981). Esses e outros dados levaram à proposição da existência de uma circulação endo-ectoperitrófica de enzimas digestivas (TERRA \& FERREIRA, 1981). De acordo com o modelo (Fig. 1.), o alimento e as enzimas caminhariam para a região posterior do tubo digestivo, enquanto que no espaço ectoperitrófico haveria 
um fluxo de ãgua da região posterior do ventrículo em direção aos cecos. Isso resultaria numa recuperação gradual das enzimas presentes no espaço endoperitrófico à medida que as moléculas polimê ricas que elas hidrolisam se tornassem pequenas o suficiente para acompanhā-las através da membrana peritrófica, e, a seguir, para os cecos (TERRA \& FERREIRA, 1981).

E interessante notar que quatro meses após ter sido publicado o modelo descrito acima, um modelo similar incluindo apenas fluxos de fluidos (as enzimas não foram consideradas) apareceu na literatura (DOW, 1981). O referido modelo foi proposto a partir, da observação do movimento de corantes no tubo $\vdots$ aigestivo do gafanhoto Schistocerca gregaria.

\subsection{Objetivos deste trabalho}

Os objetivos deste trabalho consistem em fornecer subsí dios para ampliar o conhecimento da organização espacial do pro cesso digestivo em $R$. americana e iniciar o estudo físico e cinëtico das enzimas envolvidas em digestão intermediária e final,uma vez que as hidrolases mais ativas envolvidas em digestão primária jā foram inicialmente caracterizadas (TERRA et al., 1977, 1979).

Afim de se obter um conhecimento maior da organização es pacial do processo digestivo em $R$. americana procuramos obter dados ultraestruturais e bioquímicos que puaessem apoiar, ou refutar, o modelo da circulação endo-ectoperitrófica de enzimas diges tivas (Fig. 1). Além disso, pretendemos ampliar o conhecimento da digestão terminal de proteínas em R.americana, comparando as aminopeptidases (peptideo hidrolases mais importantes) presentes em diferentes organelas das células dos cecos (principal sitio de digestão intermediāria e final de proteínas) com aquelas encontra das no fluido ectoperitrófico. 
A celobiase (EC 3.2.1.21) dos cecos gástricos foi escolhida, para iniciar o estudo detalhado das enzimas envolvidas em digestão intermediāria e final em $R$. americana, porque trata-se de enzima muito ativa e porque estudos preliminares sugeriram que existia apenas uma forma molecular da enzima. Dados referentes às enzimas digestivas ligadas a membrana plasmática, como a celobiase de $R$.americana, são particularmente desejāveis porque, tanto quanto sabemos, não existe nenhum estudo desse tipo em insetos. 


\section{MATERIAL E METODOS}

\subsection{Màteriais}

Glicose oxidase (tipo II), peroxidase (tipo II), L-aminoācido oxidase (tipo II), p-hidroximercuxibenzoato, 1,10-fenantrolina, catalase de fígado bovina, hemoglobina bovina, albumina sērica bovina, substratos sintéticos, dissacarídeos e dipeptídeos foram adquiridos da Sigma. Polylite 8001 foi adquirida da Resana S.A. (Brasil). Os anfolitos vieram da Serva (Alemanha). Todos os demais reagentes empregados foram produtos analíticos obtidos prin cipalmente da B.D.H., E. Merck e J.T. Baker. As soluções foram sempre preparadas com água bidestilada em destilador de vidro.

\subsection{Animais}

As larvas de Rhynchosciara americana (Diptera, Sciaridae) alimentam-se até o final de $2 \%$ período quase que continuadamente e são usualmente encontradas debaixo de plantas em decomposição, em bananais da orla marítima. No laboratōrio as larvas são criadas com folhas de batata doce picadas e umedecidas de acordo com LARA et al. (1965). Neste estudo utilizamos fêmeas no final do 29 período do 49 estágio (TERRA et al., 1973). Neste es tágio as larvas permanecem a major parte do tempo sobre o alimen to, de onde elas são coletadas e então dissecadas.

2.3. Obtenção de fluído luminal dos cecos e células dos cecos gãs tricos e do ventrículo

As larvas eram lavadas em água destilada, dispostas sobre gelo picado para ficarem imóveis e em seguida dissecadas em 
$\mathrm{NaCl} 0,1 \mathrm{M}$ gelado, como se segue. Os animais eram presos pela cáp sula cefálica e, com o auxílio de uma pinça, a parece do corpo era estirada, resultando em seu descolamento da cápsula cefálica. o segmento anal e as glândulas salivares eram cortadas com um estilete e o tubo digestivo removido pela parte anterior do animal. o conteúdo dos cecos era recolhido com um capilar seguido do seccionamento do tubo digestivo na altura do proventrículo e da abe $\underline{r}$ tura dos túbulos de Malpighi. A membrana peritrófica com o seu conteūdo pastoso era agora retirada do intestino médio, os cecos removidos eo ventrículo restante cortado em uma porção anterior e outra posterior. Para alguns experimentos, o ventrículo poste rior era ainda seccionado em uma porção proximal e uma distal (re gião dom dobramentos).

Os epitēlios eram lavados extensivamente em salina para remover o restante do fluído antes de serem utilizados.

\subsection{Microscopia óptica e eletrônica}

As larvas foram dissecadas como descrito acima, em $\mathrm{NaCl}$ 0,1M gelado ou em sua própria hemolinfa. Como a membrana peritró fica da larva de R.americana contēm grande quantidade de areia em seu interior (cf. TERRA \& BIANCHI, 1975), é necessário removê-la antes da fixação para não danificar a lâmina do micrótomo. Esse procedimento, entretanto, não altera a aparência do tecido quando observado em um microscópio óptico (cf. MARQUEs, 1976). Para os estudos de microscopia óptica, as seções do intestino médio foram fixadas em solução de Bouin e embebidas em parafina. Os cortes de $7 \mu \mathrm{m}$ obtidos em seguida, foram depois corados com hematoxilina $e$ eosina. Para observação do material ao microscópio eletrônico , os tecidos foram fixados por $2 \mathrm{~h}$ a $4^{\circ} \mathrm{C}$ em glutaraldeido 3\% em tam pão cacodilato $0,1 \mathrm{M} \mathrm{pH} \mathrm{7,4}$ (SABATINI et al., 1963), contendo 0,2M 
de sacarose. Após lavagem com sacarose 0,2M em tampão cacodilato, as porções do tubo digestivo foram pós-fixadas por $1 \mathrm{~h}$ a $4^{\circ} \mathrm{C}$ em tetróxido de ósmio $1 \%$ em tampão cacodilato. Posteriormente, as preparações eram lavadas em $\mathrm{NaCl} 0,1 \mathrm{M}$ e contrastadas por 16 a $18 \mathrm{~h}$ em acetato de uranila 1\%. Após desidratação, em concentrações crescentes de etanol a temperatura ambiente, o material foi embebido com a resina Polylite 8001 (COIRo et al., 1972). Os cortes ultrafinos foram obtidos em um ultramicrótomo Porter-Blum MT II, contrastados em citrato de chumbo (REYNOLDS, 1963) e examinados em um microscópio eletrônico Siemens Elmiskop IA, operado a uma voltagem $60 \mathrm{KV}$.

\subsection{Preparações de microvilosidades de diferentes regiões do in-} testino médio

o procedimento utilizado foi basicamente o descrito por SCHMITZ et al. (1973).

Células dos cecos gástricos, ventrículo anterior e ven trículo posterior eram homogeneizadas em meio hipotônico constituido por Tris 2mM-Manitol 50mM, $\mathrm{pH} 7,1$, usando-se um Omni-Mixer da Sorvall à 15.000 rpm por 20 s. Os homogeneizados eram filtrados em malha de nylon de $45 \mu \mathrm{m}$ e seu volume acertado de modo a con ter material correspondente a 10 animais por $\mathrm{ml}$.

Cloreto de cálcio sōlido foi então adicionado aos homogeneizados para ficar numa concentração final de 10mM. As suspen sões resultantes eram agitadas por $10 \mathrm{~min}$ antes de proceder - s.e as seguintes centrifugações: 
Homogeneizado (H)

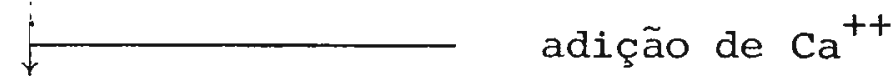

$3.300 \times g, 10 \mathrm{~min}$

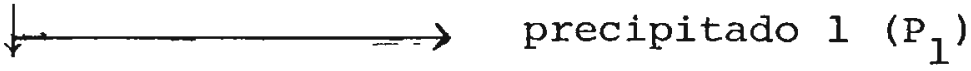

$20.000 \mathrm{xg}, 15 \mathrm{~min}$

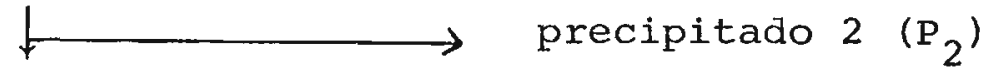

Sobrenadante

As frações podiam ser armazenadas, por pelo menos um ano a $-20^{\circ} \mathrm{C}$, sem mudança na atividade das enzimas ensaiadas.

\subsection{Fracionamento celular de células dos cecos gāstricos}

Para verificação da distribuição subcelular de enzimas, células dos cecos gāstricos eram homogeneizadas em meio isotônico consistindo da $\mathrm{KCl} 0,11 \mathrm{M} \mathrm{pH} \mathrm{7,0.} \mathrm{Lotes} \mathrm{de} \mathrm{material} \mathrm{corresponden-}$ tes a 20 larvas eram homogeneizados em 1,5ml de meio através de 5 a 10 movimentos de pistão em um homogeneizador tipo Dounce de pistilo bem ajustado (condição branda de homogeneização). Em outra série de experimentos, o tecido era homogeneizado com auxílio de um Omni-Mixer da Sorvall a $15.000 \mathrm{rpm}$ por $20 \mathrm{~s}$ (condição vigo rosa de homogeneização). Em ambos os casos, após a homogeneiza ção, o material era filtrado em malha de nylon de $45 \mu m$ e o volume do filtrado elevado de modo a conter material correspondente a 10 animais por $\mathrm{ml}$.

Em todos os casos, após retirada de uma alíquota de homogeneizado, procedia-se ao seguinte esquema de centrifugação: 
Homogeneizado (H)

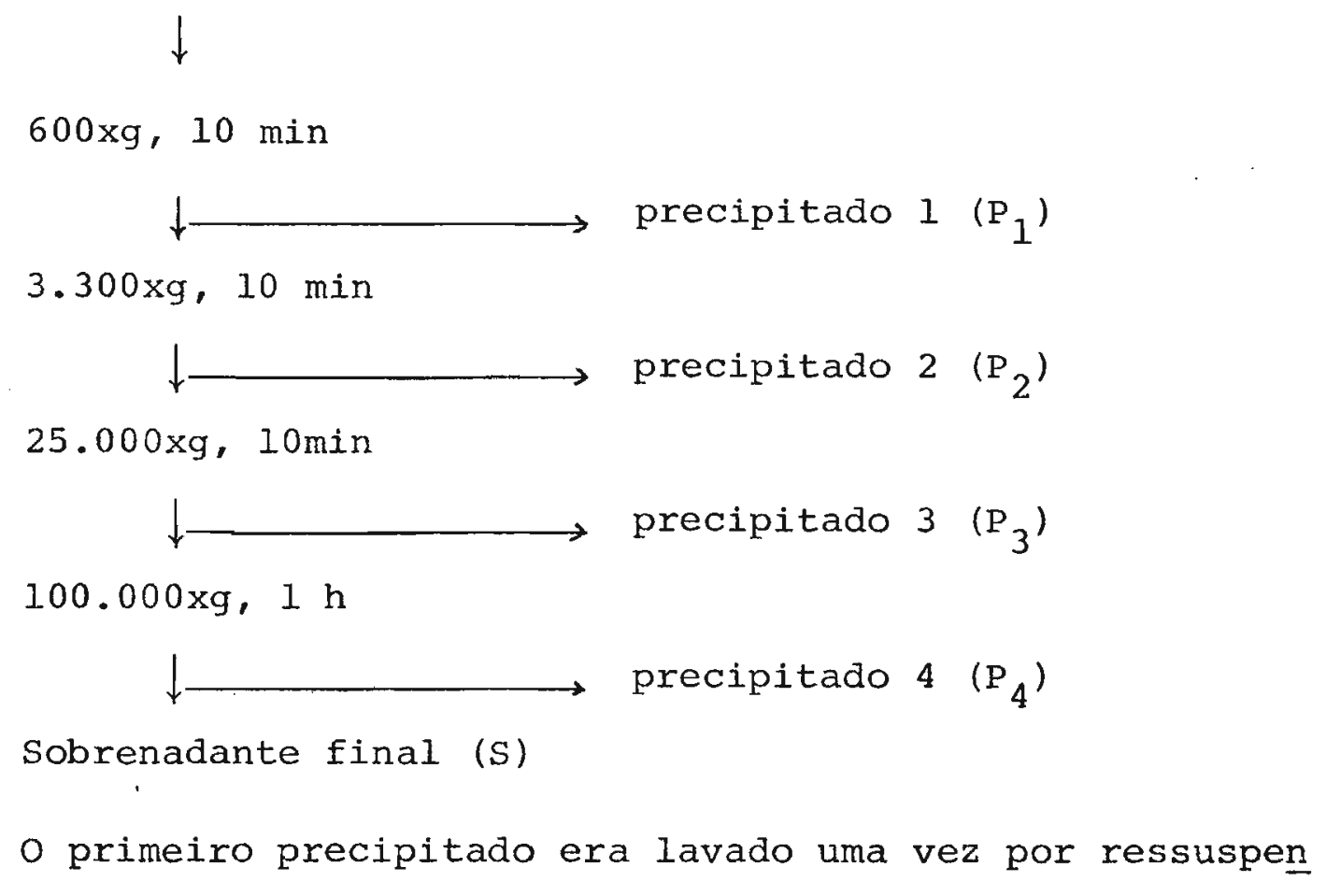
são no meio de homogeneização e os sobrenadantes reunidos antes de prosseguir-se com as centrifugações.

As frações podiam ser armazenadas, por pelo menos um ano a $-20^{\circ} \mathrm{C}$, sem mudança na atividade das enzimas ensaiadas.

2.7. Preparação das membranas dos cecos gástricos e sua solubiliza ção por Triton $\mathrm{x}-100$

Epitélio dos cecos gästricos eram homogeneizados em meio isotônico consistindo de $\mathrm{KCl} 0,11 \mathrm{M}, \mathrm{pH} 7,0$. A homogeneização era feita utilizando-se um Omni-Mixer da Sorvall a 15.000 rpm por $20 \mathrm{~s}$. A seguir, o homogeneizado era filtrado em malha de nylon de $45 \mu \mathrm{m}$ e o volume do filtrado elevado de modo a conter material corres pondente a 10 animais por $\mathrm{ml}$. Após a retirada de uma alíquota pa ra controle, o homogeneizado era centrifugado a $25.000 x g$ por 30 min e o sedimento lavado uma vez por ressuspensão no meio de homo geneização. O sedimento corresponde majoritariamente a membranas plasmāticas (cf. FERREIRA \& TERRA, 1980). Essa preparação de mem brana era a seguir exposta a Triton $\mathrm{X}-100$ por $20 \mathrm{~h}$ a $4^{\circ} \mathrm{C}$, numa ra 
$z$ ão de $10 \mathrm{mg}$ de Triton $\mathrm{x}-100 / \mathrm{mg}$ de proteina, antes do material ser centrifugado a $25.000 \mathrm{xg}$ por $30 \mathrm{~min}$. O sobrenadante era utilizado como fonte de enzimas, após adicionar-se igual volume de Triton $\mathrm{X}-100$ 58. A centrifugação desse sobrenadante por $60 \mathrm{~min}$ a $100.000 \mathrm{xg}$ não leva à formação de nenhum sedimento e a sua atividade em relação às enzimas ensaiadas permanece inalterada, se mantido a $-20^{\circ} \mathrm{C}$, por período de pelo menos um mês.

\subsection{Solubilização de hidrólases da membrana dos cecos por papaí-} $\underline{\text { na }}$

Membranas dos cecos gāstricos foram preparadas como des crito no item 2.7 . e o sedimento obtido homogeneizado em tampão fosfato de potássio $0,1 \mathrm{M}, \mathrm{pH} 7,0 \mathrm{com}$ auxilio de um homogeneizador Potter-Elvehjem.

Para ativar a papaina, 2,8mg da enzima foram incubadas, a $37^{\circ} \mathrm{C}$ por $5 \mathrm{~min}$, na presença de tampão fosfato de potássio $62 \mathrm{mM}$, pH 7,0 e cisteína 50mM. A suspensão de membranas obtidas como descrito acima era incubada com papaina ativada a $30^{\circ} \mathrm{C}$, numa razão de lmg de papaína/lomg de proteína de membrana. Aliquotas eram retiradas em tempos diferentes e TLCK era adicionado para ficar num excesso molar de 20 vezes em relação a papaína. Após diluir duas vezes com āgua gelada, as alíquotas eram centrifugadas a $100.000 x y$ por $1 \mathrm{~h}$ e os sobrenadantes utilizados como fonte de enzima. A atividade das enzimas ensaiadas nessas preparações, se mantidas a $-20^{\circ} \mathrm{C}$, permanecem inalteradas por pelo menos um ano.

2.9. Determinação do peso molecular por centrifugação em gradiente de densidade 
lubilizadas com Triton X-100 ou com papaína, contendo $1,5 \mathrm{mg}$ de he moglobina bovina e $50 \mu \mathrm{g}$ de catalase de fígado bovina, foram aplicadas no topo de gradientes contínuos de glicerol (glicerol 5 a $108(\mathrm{P} / \mathrm{V})$ em tampão fosfato $\mathrm{pH} 6,250 \mathrm{mM})$ de $4,6 \mathrm{ml}$. Esses mate riais foram centrifugados a $96.000 \mathrm{xg}$ por $15 \mathrm{~h}$ a $4^{\circ} \mathrm{C}$ e alíquotas $(0,2 \mathrm{ml})$ foram coletados a partir do fundo de cada tubo com o auxí lio de uma bomba peristáltica. O peso molecular das enzimas ensaidas nessas frações foi calculado segundo MARTIN \& AMES (1961), usando como referência as sedimentações da hemoglobina (PM 64.500) e catalase (PM 232.000) adicionadas à amostra. A posição da hemo globina nos gradientes foi verificada determinando-se a absorbância das frações a 545nm e a da catalase, realizando-se ensaios da enzima segundo MARTIN \& AMES (1961). A recuperação da atividade aplicada aos gradientes, para as diferentes enzimas ensaiadas, foi de cerca de $100 \%$.

\subsection{Eletroforese e determinação de atividades enzimāticas em géis de poliacrilamida}

As amostras de diferentes preparações de enzima ( fluido luminal dos cecos, citossol e membranas das células dos cecos solubilizadas em Triton ou papaína , foram aplicadas a géis de poliacrilamida preparados segundo HEDRICK \& SMITH (1968) em tubos de $5 \mathrm{~mm}$ de diâmetro interno e $10 \mathrm{~mm}$ de comprimento. A separação eletroforêtica foi obtida com uma corrente de $2,5 \mathrm{~mA}$ por columa a $4^{\circ} \mathrm{C}$.

Quando se desejava detectar atividade de glicosidases , a concentração de Tris nos géis era diminuída imergindo-os por 60 min em tampão fosfato $10 \mathrm{mM}, \mathrm{pH} 6,0$ a $4^{\circ} \mathrm{C}$. Esse tampão era tro cado em intervalos de $20 \mathrm{~min}$. 
acrilamida (Autogeldivider Savant Instruments, USA) com tampão fos fato 0,1M, pH 6,2 (géis utilizados para detecção de glicosidases) ou com tampão fosfato $0,1 \mathrm{M}, \mathrm{pH} 8,0$ (géis utilizados para detecção de aminopeptidases). Frações de 9 gotas (correspondentes a $2 \mathrm{~mm}$ do gel) foram coletadas e um volume do mesmo tampão utilizado no fracionamento foi adicionado a cada uma delas. Esse tampão con tinha Triton $x-1000,18$, quando era feita eletroforese de mate rial solubilizado em Triton X-100. As frações permaneciam por 3 a $20 \mathrm{~h}$ a $4^{\circ} \mathrm{C}$, sendo a seguir filtradas em papel whatman no 41 e desse filtrado eram retiradas alíquotas para os vários ensaios. A recuperação da atividade aplicada aos gēis, para as diferentes en zimas ensaiadas, foi de cerca de $77 \%$

\subsection{Eletrofocalização e determinação de atividades enzimáticas nos géis}

Os géis de poliacrilamida $7,5 \%$ utilizados continham an folitos pH 4-6 e pH 5-7 ( $1 \%$ de cada anfolito) e tambēm Triton X-100 0,17\%, no caso de eletrofocalização de enzimas solubilizadas nesse detergente. Para que a aplicação fosse feita do lado alcalino, sem que a enzima entrasse em contato com a solução presente no banho (NaOH), deixava-se um espaço de $1 \mathrm{~cm}$ na parte superior do tubo, onde colocava-se 0,15ml de uma mistura de glice -

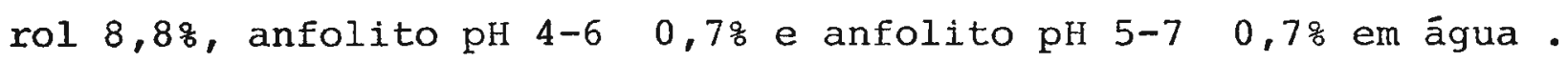
Sobre essa solução, após uma pré-focalização de $30 \mathrm{~min}$, aplicavase a preparação de enzima contendo glicerol 11,4\%. Seguia-se uma eletrofocalização a $4^{\circ} \mathrm{C}$ por 2 a $3 \mathrm{~h}$ com uma voltagem de $31 \mathrm{~V} / \mathrm{Cm}$.

Apōs focalização, os gēis foram divididos em frações e tratados como descrito no item 2.10 .

O gradiente de $\mathrm{pH}$ ao longo dos géis era determinado frá cionando um cilindro de gel preparado de forma idêntica aos demais, 
com āgua bidestilada no lugar do tampão. O pH de suas frações era medido com um eletrodo de vidro, após permanecer por $3 \mathrm{~h}$ a tempe ratura ambiente. Em alguns casos, essas mesmas frações foram uti lizadas para medida de atividade enzimática. A recuperação da atividade aplicada aos géis, para as diferentes enzimas ensaiadas, foi de cerca de 74 응

\subsection{Determinação de atividades enzimáticas e de proteínas}

Os ensaios enzimáticos foram realizados como descrito na Tabela I.

Em cada determinação, a mistura de reação foi incubaảa por $30,60,90$ e $120 \mathrm{~min}$, com exceção daquelas que continham $\delta-$ gliconolactona. Controles sem enzima (brancos de substrato) e sem substrato (brancos de enzima) foram incubados do mesmo modo que os experimentais. A atividade calculada foi expressa em nmo les de substrato hidrolisado por min (mUnidades, mU).

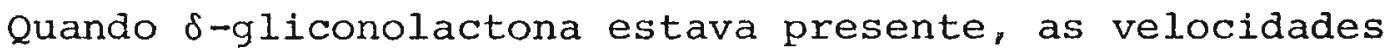
iniciais foram calculadas a partir de incubações realizadas por $20 \mathrm{~min}$ a $30^{\circ} \mathrm{C}$ em tampão fosfato $100 \mathrm{mM}, \mathrm{pH} 6,2$. Nessas condições,

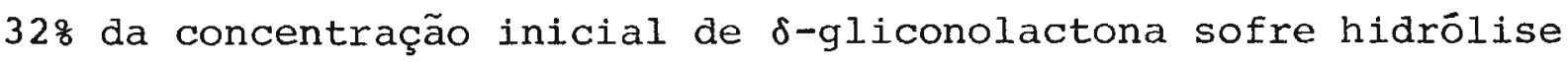
espontânea, embora não aìtere o pH do meio de incubação. A ausên cia de lactonase (EC 3.1.1.17) em nossas preparações de membrana foi assegurada pela medida da concentração de $\delta$-gliconolactona re manescente (HESTRIN, 1949) em diferentes tempos, na presença e ausência de nossas preparações. O ácido glicônico, para ser usado como inibidor, foi preparado como se segue. Soluções de $\delta-$ gliconolactona $2,0 \mathrm{mM}$ em tampão fosfato $0,2 \mathrm{M}$ pH 8,0 foram incuba das a $30^{\circ} \mathrm{C}$ por $4 \mathrm{~h}$. Apōs esse tempo elas foram diluídas com tam pão fosfato $0,2 \mathrm{M}$ pH 6,2 e seus valores de $\mathrm{pH}$ ajustados para 6,2 . 


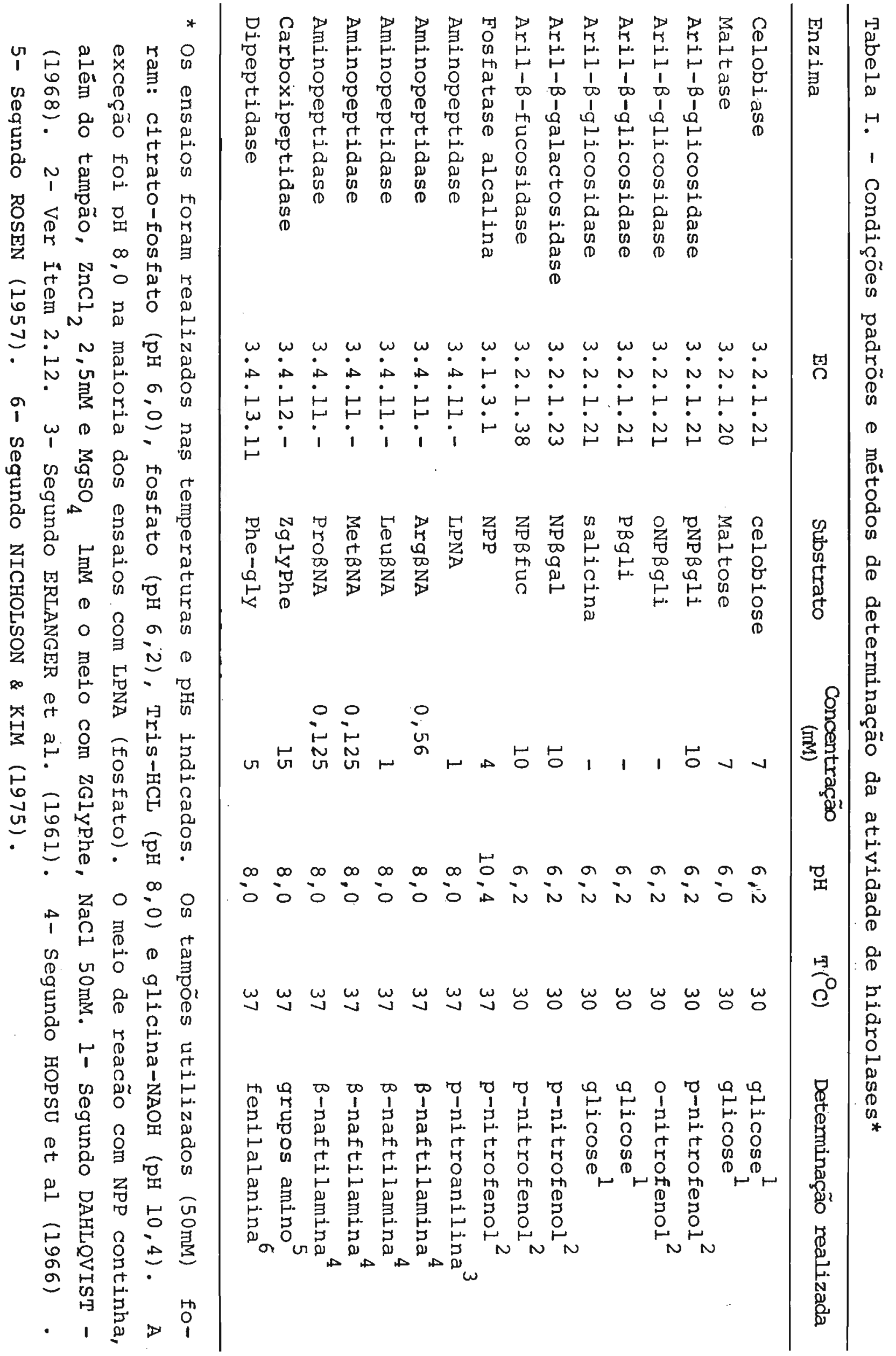


nos pHs indicados em um volume de reação de $0,2 \mathrm{ml}$ e a reação interrompida pela adição de 1 : ml de tampão bicarbonato $0,25 \mathrm{M}$ carbo nato $0,25 \mathrm{M}$ e SDS 1\%. Em experimentos controles, verificou-se que essa concentração desnatura todas as enzimas ensaiadas. Nessas condições, o coeficiente de extinção molar a $420 \mathrm{~nm}$ do p-nitrofeno lato é 18.000 e do o-nitrofenolato é 4.600 .

E importante ressaltar que todos os sedimentos obtidos por centrifugação eram suspensos por reomogeneização em homogenei zador tipo Potter-Elvehjem. Quando essa providência não é tomada antes de realizar-se os ensaios enzimáticos, a recuperação total das enzimas particuladas fica bastante diminuida. Também deve-se salientar que em todọs os meios de reação para ensaios de enzimas previamente solubilizadas em Triton $x-100$, a concentra ção desse detergente nunca ficou abaixo de 0,05\%. Experimentos controle mostraram que a atividade das enzimas é constante em todas as concentrações de Triton utilizadas nos ensaios.

Para a determinação de proteinas, um volume de $\mathrm{HClO}_{4}$ 1, ON gelado era adicionado à amostra de concentração proteica des conhecida. Após esperar $10 \mathrm{~min}$ no gelo, a suspensão era centrifu gada a $10.000 \mathrm{xg}$ por $10 \mathrm{~min}$ e o sedimento resultante lavado com $\mathrm{HClO}_{4} 0,3 \mathrm{~N}$. Esse sedimento, apōs solubilização em NaOH 1,0N , era utilizado na determinação de proteinas segundo LOWRY et al . (1951), empregando-se albumina de soro bovino como padrão.

\subsection{Inibição da hidrólise de celobiose por pNPßgli e inibição da hidrólise de pNPßgli por celobiose}

Afim de se determinar a atividade sobre pNPBgli e sobre celobiose, quando os substratos encontravam-se presentes simultaneamente nos meios de incubação, uma alíquota era retirada de cada amostra para determinar p-nitrofenolato, e daí estimar a 
hidrólise de pNPßgli, e outra aliquota era utilizada para medida de glicose. A determinação de glicose nesse experimento era feita adicionando-se $\mathrm{H}_{2} \mathrm{SO}_{4}$ ao final da incubação com o reagente de glicose oxidase-peroxidase (DAHLQVIST, 1968). Nessas condições , - p-nitrofenol encontra-se protonado e não interfere na leitura da absorbância, necessária para a medida de glicose. Após descon tar-se (a partir das medidas de p-nitrofenolato) as moléculas de glicose produzidas na hidrólise de pNPßgli, obtinha-se uma medida da atividade sobre celobiose.

2.14. Identificação da configuração da glicose liberada pela celobiase solubilizada em papaína

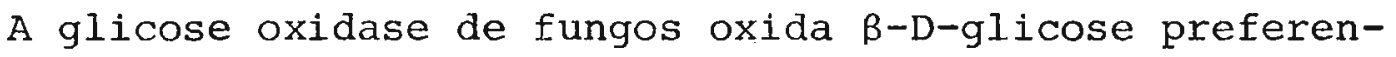
cialmente (KEILIN \& HARTREE, 1952) e, por isso, ela tem sido usada, juntamente com peroxidase e um corante aceptor de eletrons , na identificação da configuração anomérica da glicose liberada por dissacaridases (p.ex. SEMENZiA et al., 1969).

Afim de se identificar a configuração da glicose libera da pela celobiase solubilizada por papaína, a celobiase foi incubada por $15 \mathrm{~min}$ à temperatura ambiente $\left(24^{\circ} \mathrm{C}\right)$ em tampão acetato $20 \mathrm{mM}$ pH 5,6 com oNPBgli. O tampão acetato foi utilizado no lugar do tampão fosfato porque esse último íon acelera o processo de anomerização (SCHRAY \& BENKOVIC, 1978). Ao término dos 15 min, inibia-se a celobiase pela adição de $\delta$-gliconolactona (final lmM) ao meio de incubação e retirava-se deste uma alíquota de 0,1 $\mathrm{ml}$ antes e outra apōs ferve-lo por $5 \mathrm{~min}$. Ås alíquotas, adicionavase $1 \mathrm{ml}$ de reagente de glicose oxidase-peroxidase (DAHLQVIST,1968) e a absorbância era a seguir lida continuamente a $420 \mathrm{~nm}$. Uma ter ceira alíquota era retirada do meio de incubação para a determina ção da glicose liberada a partir da quantificação do o-nitrofenol 
liberado.

Os controles foram preparados como as amostras :experimentais, substituindo o substrato por uma solução de $\alpha-D-g l i c o s e$ recēm preparada ou por uma solução de $\alpha-D-g l i c o s e ~ p r e v i a m e n t e ~ f e \underline{~}$ vida, ambas soluções com concentrações de glicose iguais a das amostras experimentais. Os controles foram incubados por 7,5 min antes da adição de $\delta$-gliconolactona e reagente de glicose oxidase-peroxidase.

A ausência de mutarrotase (EC 5.1.3.33) em nossas prepa rações foi assegurada pelos resultados idênticos obtidos na incu-

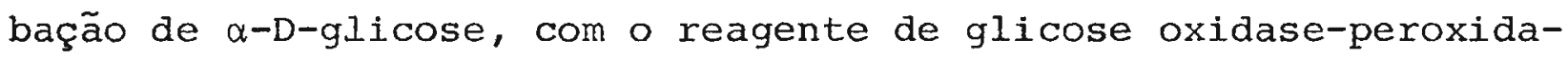
se, na presença e ausência de nossas preparações. 


\section{RESULTADOS}

3.1. Atividade de arilamidases nas frações subcelulares e conteúdo luminal dos cecos gástricos

As vārias frações particuladas das células dos cecos gās tricos são semelhantes entre si, apresentando uma maior atividade sobre LeußNA em tampão Tris, uma atividade intermediária sobre LpNA em tampão Tris e uma menor atividade sobre LpNA em tampão fosfato, enquanto que o contrārio é observado para a fração solúvel (Tạ bela II). O conteúdo luminal dos cecos apresenta uma atividade de arilamidase semelhante àquela da fração solúvel.

A hidrólise de diferentes aminoacil- - -naftilamidas e Phe-Gly nas frações particuladas (Figura 2), ocorre principalmen te em $\mathrm{P}_{1}$, quando se utiliza condições brandas de homogeneização, e na fração $\mathrm{P}_{3}$, quando o homogeneizado utilizado foi obtido em condições vigorosas. Essas atividades hidrolíticas são também en contradas no sobrenadante final (Figura 2) • Os dados sugeremque as arilamidases e Phe-Gly hidrolase ocorrem ligadas à membrana plasmática e no citossol das células dos cecos. Essa conclusão é compatível com o fato de que após homogeneização branda, a membra na plasmātica produz fragnentos grandes que sedimentam-se principalmente em baixas acelerações. Por outro lado, quando a homogeneização é mais vigorosa, os fragmentos de membrana plasmātica re sultantes são menores e sedimentam-se somente em acelerações mais elevadas (EVANS, 1978), como é evidenciado pela distribuição de fosfatase alcalina, marcadora da membrana plasmática (Fig. 2 e FERREIRA \& TERRA, 1980). Não há evidências para a ocorrência de qualquer quantidade significativa de arilamidases (ou Phe-Gly hidrolase) em lisossomos. Se isso acontecesse, no fracionamento fei to a partir de homogeneizado obtido em condições brandas de homogeneização a atividade específica na fração $\mathrm{P}_{3}$ deveria ser maior 
Figura 2 - Distribuição da atividade de arilamidase, sobre vários substratos, em frações subcelulares dos cecos' gástricos de R.ame ricana. A, homogeneização branda. B, homogeneização vigorosa. Os ensaios foram realizados em tampão Tris $50 \mathrm{mM}$, pH 8,0 . Fosfatase alcalina é um marcador da membrana plasmática das células dos ce cos (Cf. FERREIRA \& TERRA, 1980). Os resultados são apresentados segundo DE DUVE et al., (1955). As frações são representadas da esquerda para a direita na ordem em que foram obtidas $\left(\mathrm{P}_{1}, \mathrm{P}_{2}\right.$, $\mathrm{P}_{3}, \mathrm{P}_{4}$ e $\mathrm{S}$, respectivamente). Os dados são valores representativos obtidos para uma das 3 determinações independentes realiza das. 
A

B

fosfatase alcalina
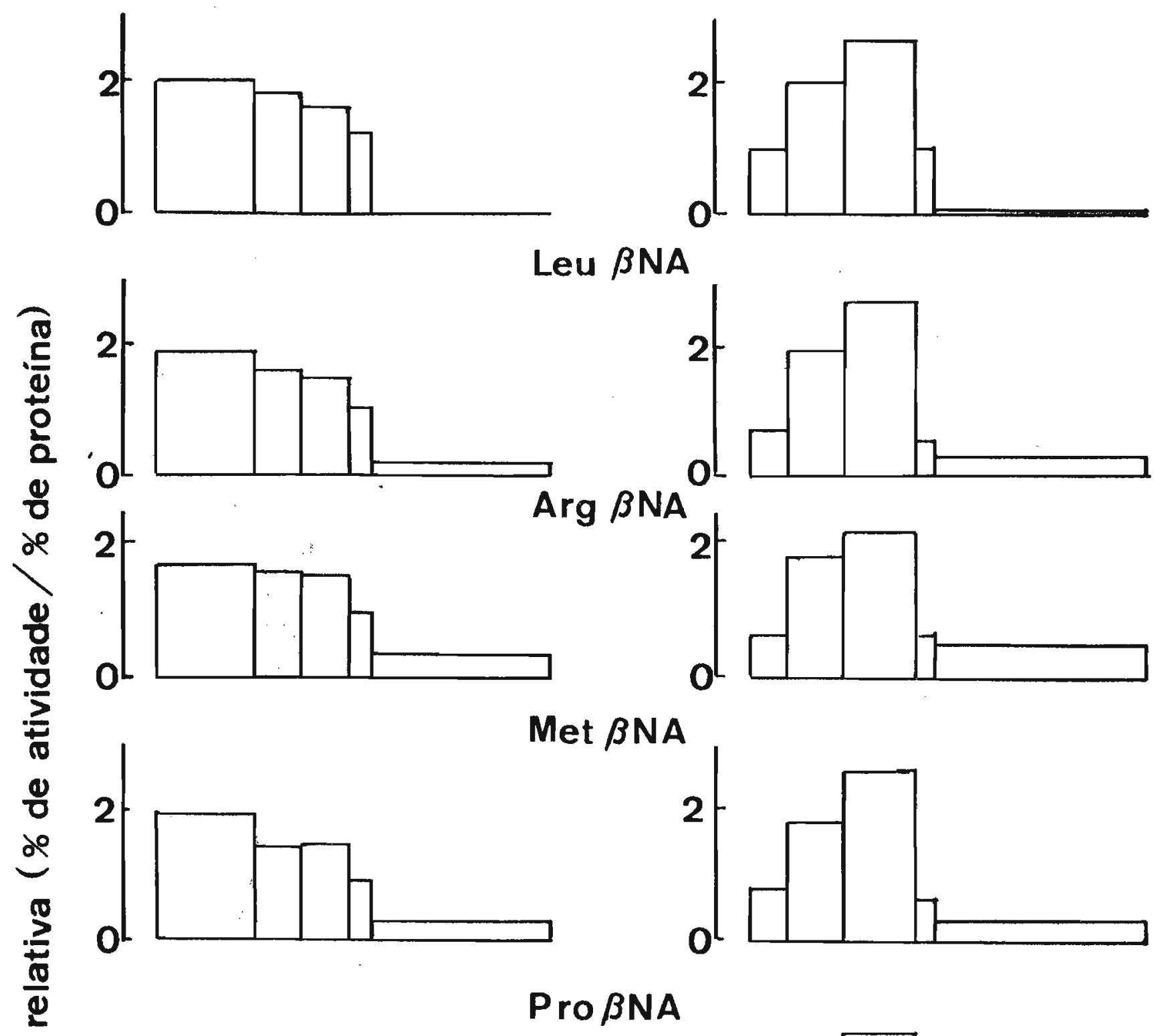

$\begin{array}{ll}8 & 2 \\ \frac{0}{8} & \\ \frac{8}{8} & 0\end{array}$

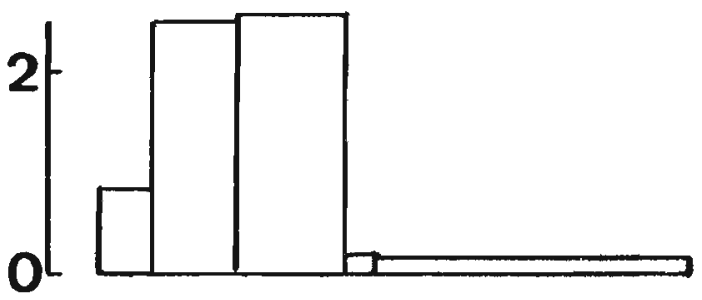

$\sum_{\frac{0}{0}}^{\frac{0}{0}}{ }^{2}$
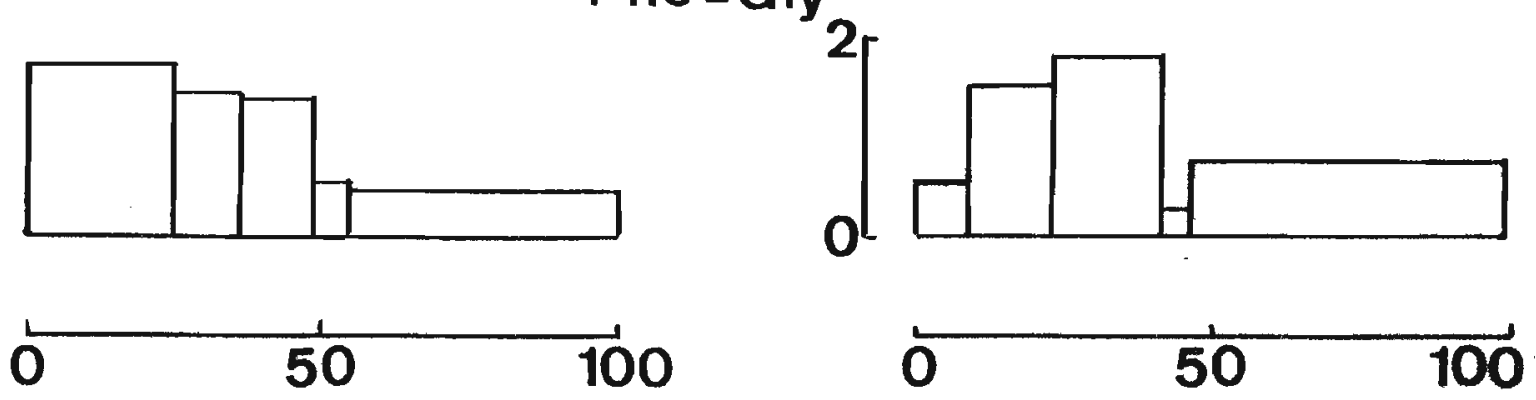

\% da proteína total 


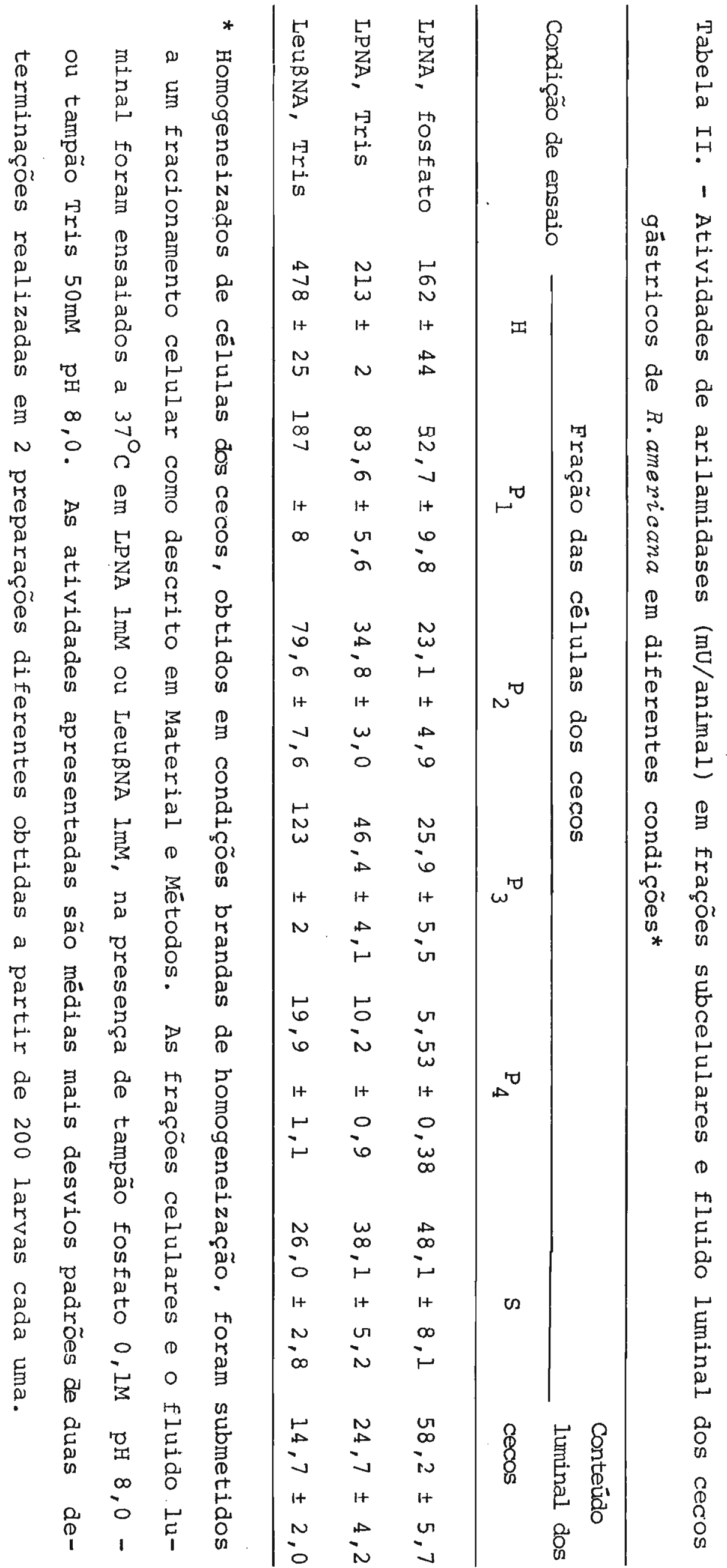




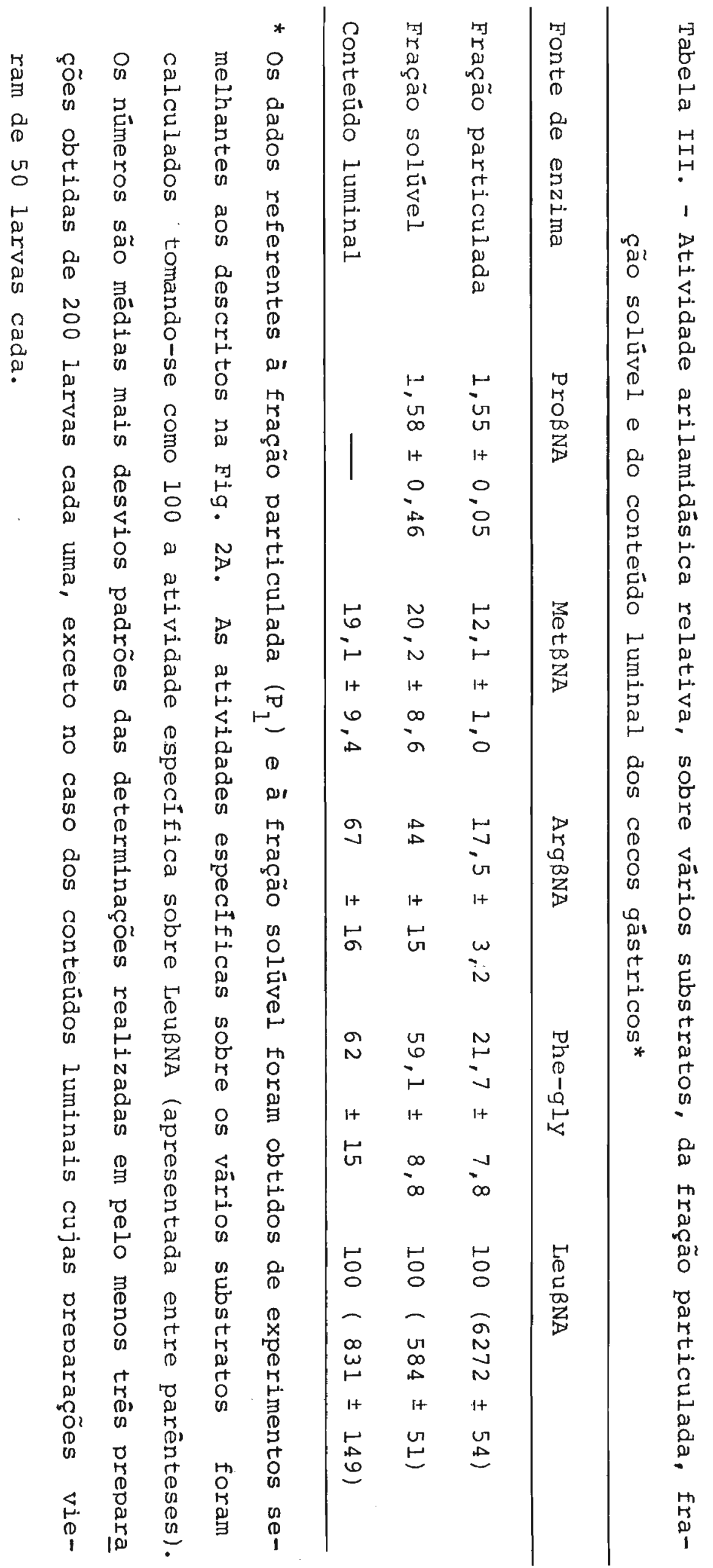


do que na fração $\mathrm{P}_{1} \mathrm{e}$, após homogeneização vigorosa, parte da ati vidade das arilamidases particuladas deveria ser transferida para a fração solúvel (cf. FERREIRA \& TERRA, 1980).

Os dados apresentados na Tabela III confirmam as conclu sões tiradas dos dados da Tabela II: as enzimas ligadas a membra nas são diferentes das de citossol, que por sua vez são semelhantes àquelas presentes no fluído ectoperitrófico.

Como as hidrolases particuladas parecem estar ligadas à membrana, as microvilosidades dos cecos foram purificadas e usadas como fonte de enzimas de membrana no estudo do efeito de vários compostos sobre sua atividade. As preparações de microvilosidades provavelmente são muito menos contaminadas por enzimas solúveis que qualquer outra fração particulada obtida por centrifugação diferencial (cf. FERREIRA \& TERRA, 1980). A atividade arilamidāsica de microvilosidades, citossol e fluído luminal foi inibida (Tabela IV) por metais pesados $\left(\mathrm{Zn}^{2+}, \mathrm{Co}^{2+} \mathrm{e} \mathrm{Mn}^{2+}\right)$ e por fenantrolina, mas foi pouco afetada por $\mathrm{Ca}^{2+}, \mathrm{Mg}^{2+}$ e EDTA. A ati vidade arilamidásica das microvilosidades foi bastante inibida por PHMB, enquanto as arilamidases de citossol e lúmen foram pouco afetadas por essa substância.

3.2. Eletroforese de arilamidases presentes no citossol e lúmen dos cecos gástricos

A atividade arilamidásica do citossol dos cecos apresen ta 3 picos principais $(2,4$ e 5) e 2 picos minoritários ( 1 e 3 ) após separação eletroforética (Fig. 3) . A arilamidase 1 de citossol é muito mais ativa sobre LeuBNA que sobre LPNA e algumas vezes ela se separa completamente do pico 2, como na Fig. 3c, que apresenta resultados obtidos de uma eletroforese de enzimas lumi nais. As arilamidades 4 e 5 de citossol resolvem-se mal, embora 


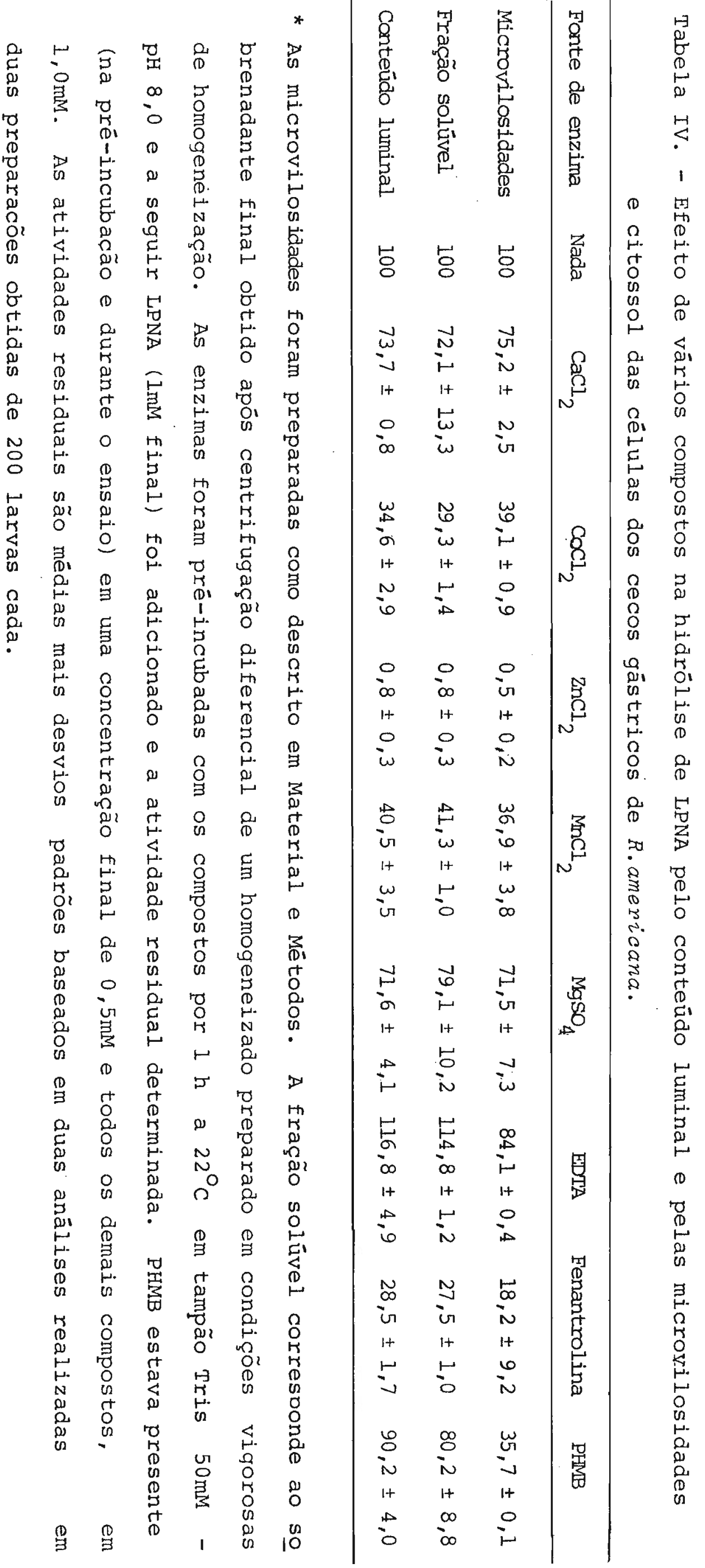




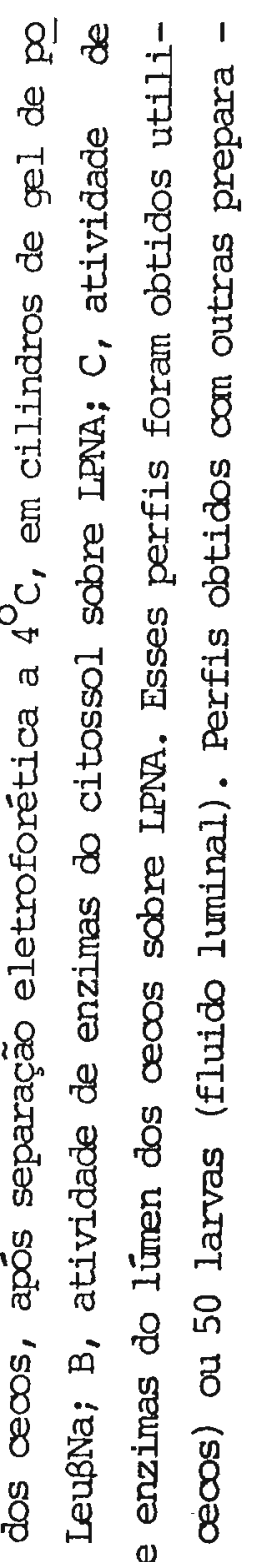

焉尊

0

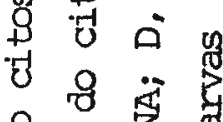

\% व

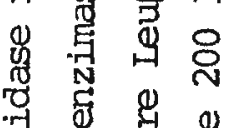

न्दु क्ष

7 व 0

8 .

\&

5 स 5 \%

要点兽

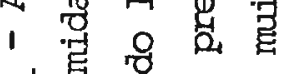

m|

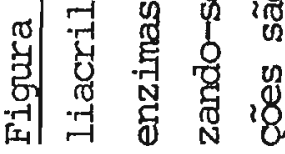



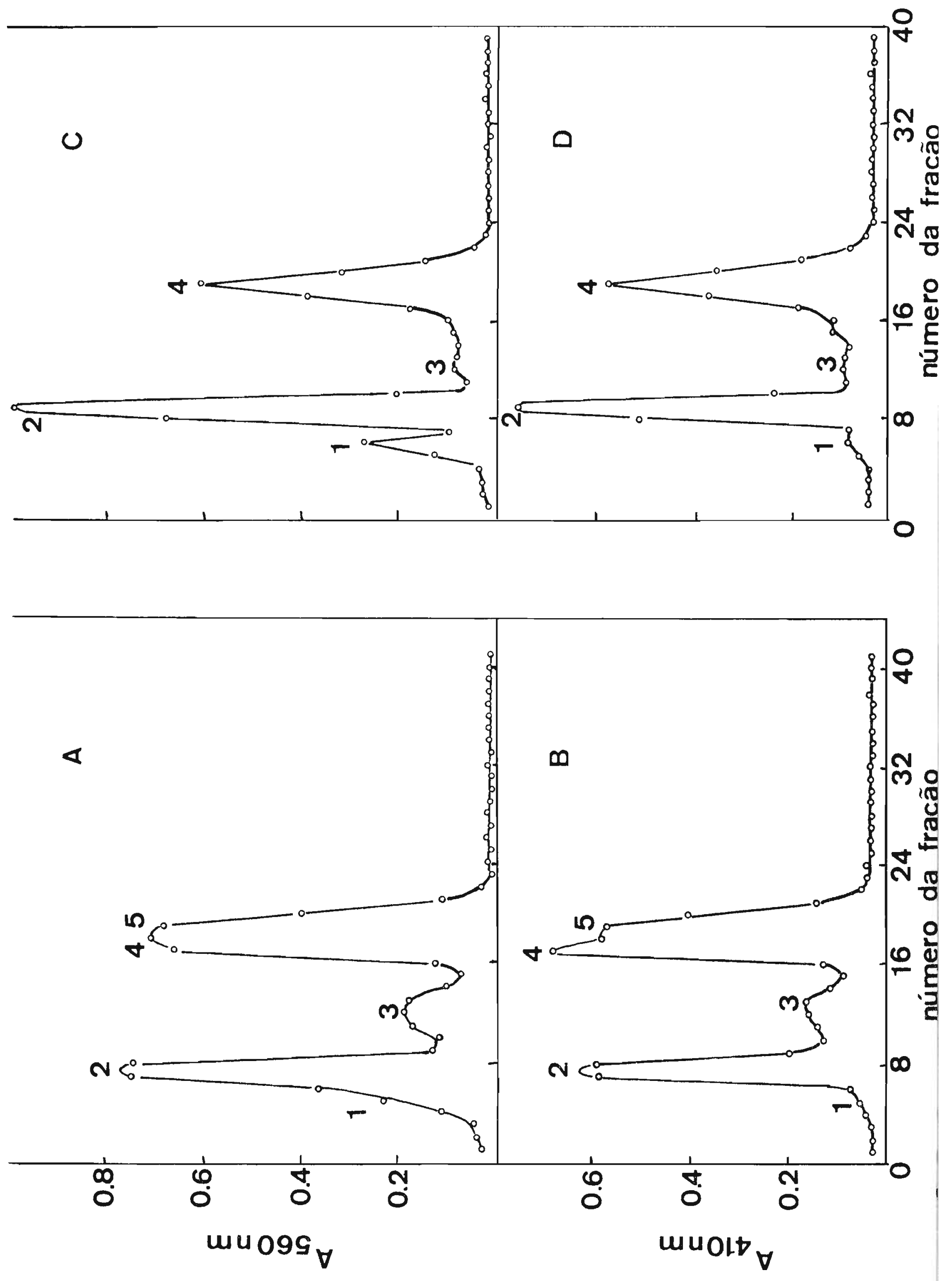
possam ser diferenciadas pela observação de suas atividades sobre LPNA. A razão de migração e a razão de atividade sobre LeußNA e LPNA apoiam a suposição de que as arilamidades luminais são idênticas às arilamidases presentes no citossol, com exceção da arila midase 5, que não é encontrada no fluido luminal, aparecendo unicamente no citossol.

\subsection{Histologia do intestino médio de R. americana}

O tubo digestivo da larva de R. americana é composto por um pequeno intestino anterior, um intestino médio longo, com 2 cecos gāstricos conectados à região anterior, e um intestino pos terior de paredes finas. Entre o intestino anterior e o intestino médio existe um pró-ventrículo e a região onde os túbulos de Malpighi encontram o intestino delimita a transição entre o intes tino médio e o posterior.

Uma larva madura pesa cerca de $50 \mathrm{mg}$ e possui um ventrículo cilíndrico de cerca de $16 \mathrm{~mm}$ de comprimento e 1,5mm de diâmetro. Os cecos gástricos tem cerca de $10 \mathrm{~mm}$ de comprimento e 0,8mm de diâmetro. A parede interna dos cecos e do quarto posterior do ventrículo é enrugada. Esse enrugamento é um reflexo de um dobra mento do epitélio (Figs. $4 b$ e c). As células dos cecos gástricos são poliédricas, com microvilosidades cobrindo suas faces apicais (Fig. 4c.). As células ventriculares variam em aspecto ao longo do comprimento do ventrículo, que pode ser considerado como dividido em 4 regiões: ventrículo anterior proximal e distal e ventrículo posterior proximal e distal (região com dobramentos) . O ventrículo anterior proximal apresenta células achatadas, com núcleos apicais, enquanto que no ventrículo anterior distal encon tramos grandes células colunares com células menores intercala das irregularmente, as células regenerativas (Fig. 4a.). iNo ven- 
Figura 4 - Cortes histológicos do intestino médio da larva de $R$. americana. (a) Células da região proximal do ventrículo anterior (metade inferior do campo) com nūcleos apicais e células da região distal do ventrículo (metade superior do campo) mostrando cé lulas colunares com células regenerativas intercaladas. O ventrículo anterior apresenta-se colapsado devido à remoção da membrana peritrófica na dissecção. Os cecos gástricos apresentam um bordo

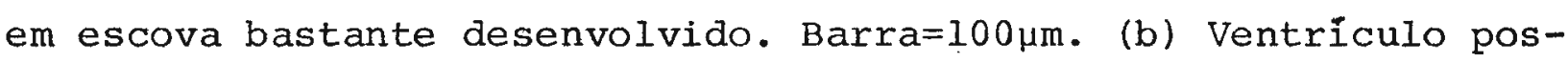
terior proximal (metade superior) e ventrículo posterior distal -

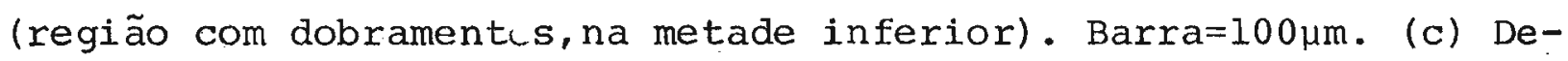

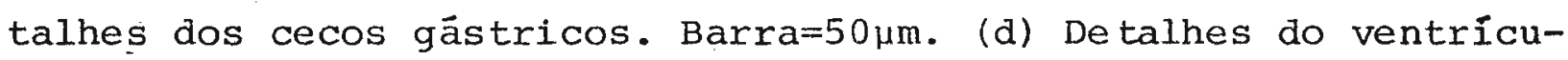
10 posterior distal. Barra=50 $\mathrm{m}$. (AV) ventriculo anterior; (BB) bordo em escova; (GC) cecos gástricos; (L) lümen; (N) Nūcleo; (RC) células regenerativas. 

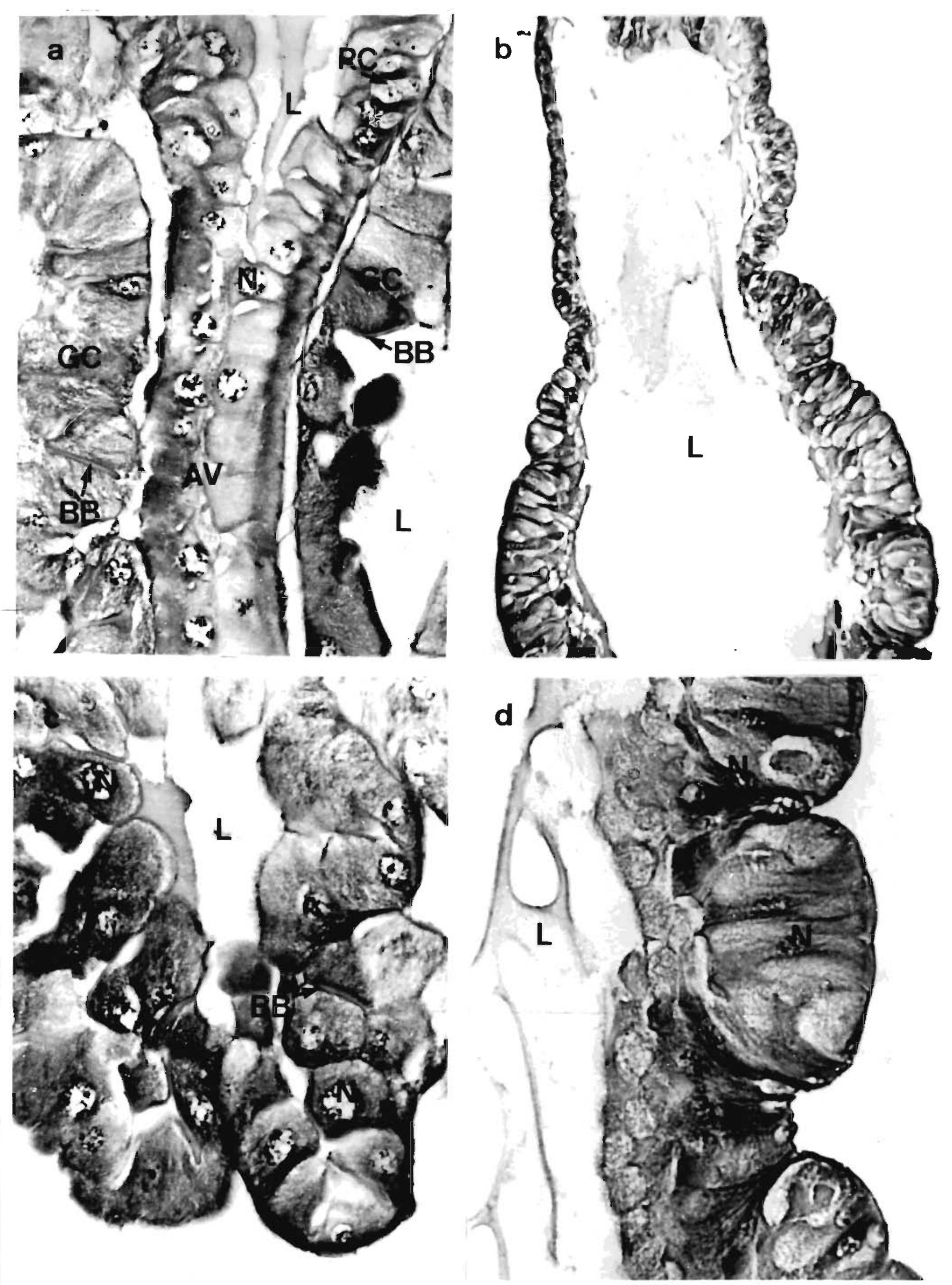
trículo posterior distal (região com dobramentos), células aproxi madamente colunares estão arranjadas em grupos, em grandes dobramentos epiteliais, formando profundas criptas multicelulares (Fig. 4d). Dependendo da posição das células nas criptas multicelulares, formam-se pequenas criptas entre células adjacentes. O ventrículo posterior proximal é uma região de transição entre o ventrículo anterior distal e o ventrículo posterior distal. Assim, suas células assemelham-se inicialmente aquelas do ventrỉculo anterior e, conforme se vai para as regiões mais posteriores, as cé lulas apresentam faces apicais convexas, com pequenas criptas entre células adjacentes, e com dobramentos em sua lâmina basal (Fig. 4 b).

\subsection{Ultraestrutura das células dos cecos gástricos}

A membrana plasmática apical das células dos cecos gāstricos é modificada em microvilosidades cilindricas que apresen tam um arranjo hexagonal (Fig. 5C). As microvilosidades tem cer ca de $3,8 \mu \mathrm{m}$ de comprimento e são cobertas por um proeminente glicocálix. No citoplasma de cada microvilosidade, ocorrem microfi lamentos que podem ser vistos penetrando ligeiramente no citoplas ma apical, abaixo da base das microvilosidades.

A membrana plasmática lateral tem uma superfície pequena, devido a existência de criptas profundas entre células adja centes (Fig. 4c e 5c). Essa membrana apresenta dobramentos irre gulares, algumas vezes modificados em interdigitações, ao :Iongo dos complexos funcionais, que são principalmente junções septadas (Fig. 5c). A membrana plasmātica basal apresenta invagingações com poucas aberturas para o espaço extracelular subjacente (Fig. 5b). Existem vārias mitocôndrias associadas a essas invaginações, embora elas sejam particularmente abundantes no citoplasma 
Figura 5 - Cecos gástricos da larva de R.americana. (a) Detalhe do ápice de uma célula dos cecos gástricos. (b) Detalhe da base de uma dessas células. Observam-se algumas aberturas (setas) pa ra o espaço extracelular subjacente. (c) Detalhe do ápice de duas células dos cecos gāstricos. (BI) invaginações basais; (BL) lâmina basal; (G) complexo de Golgi; (JC) complexo juncional. ; (LM) músculo longitudinal; (LS) esfera lipídica; (Ly) lisossomo; (Mi) mitocôndria; (Mv) microvilosidade; (N) núcleo; (RER) retículo endoplasmático rugoso; (SER) retículo endoplasmático liso. Barra $=1 \mu \mathrm{m}$. 

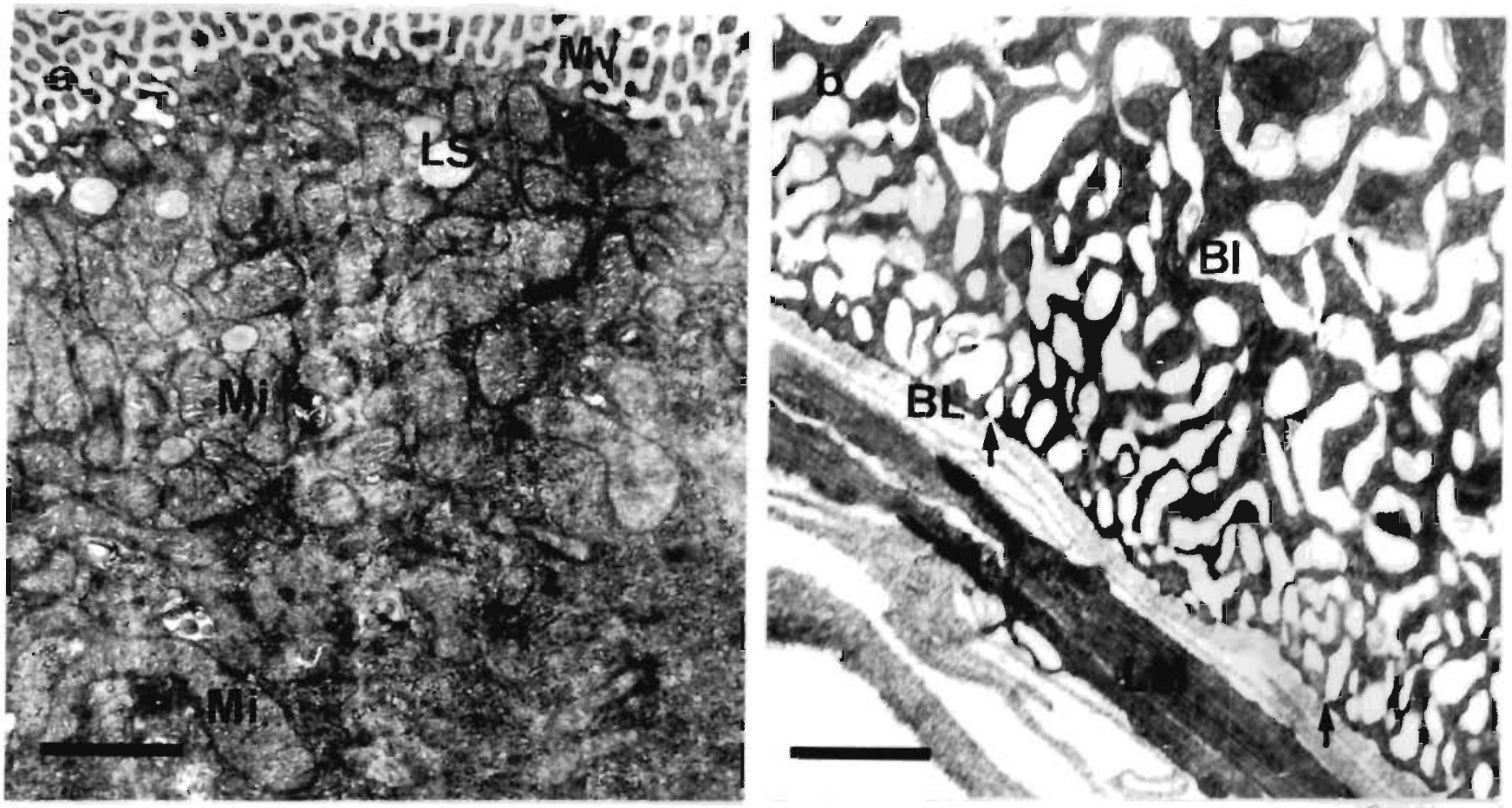

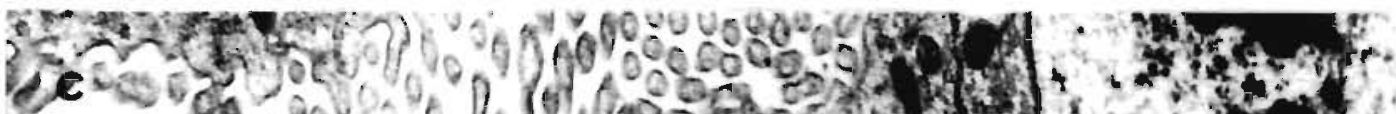

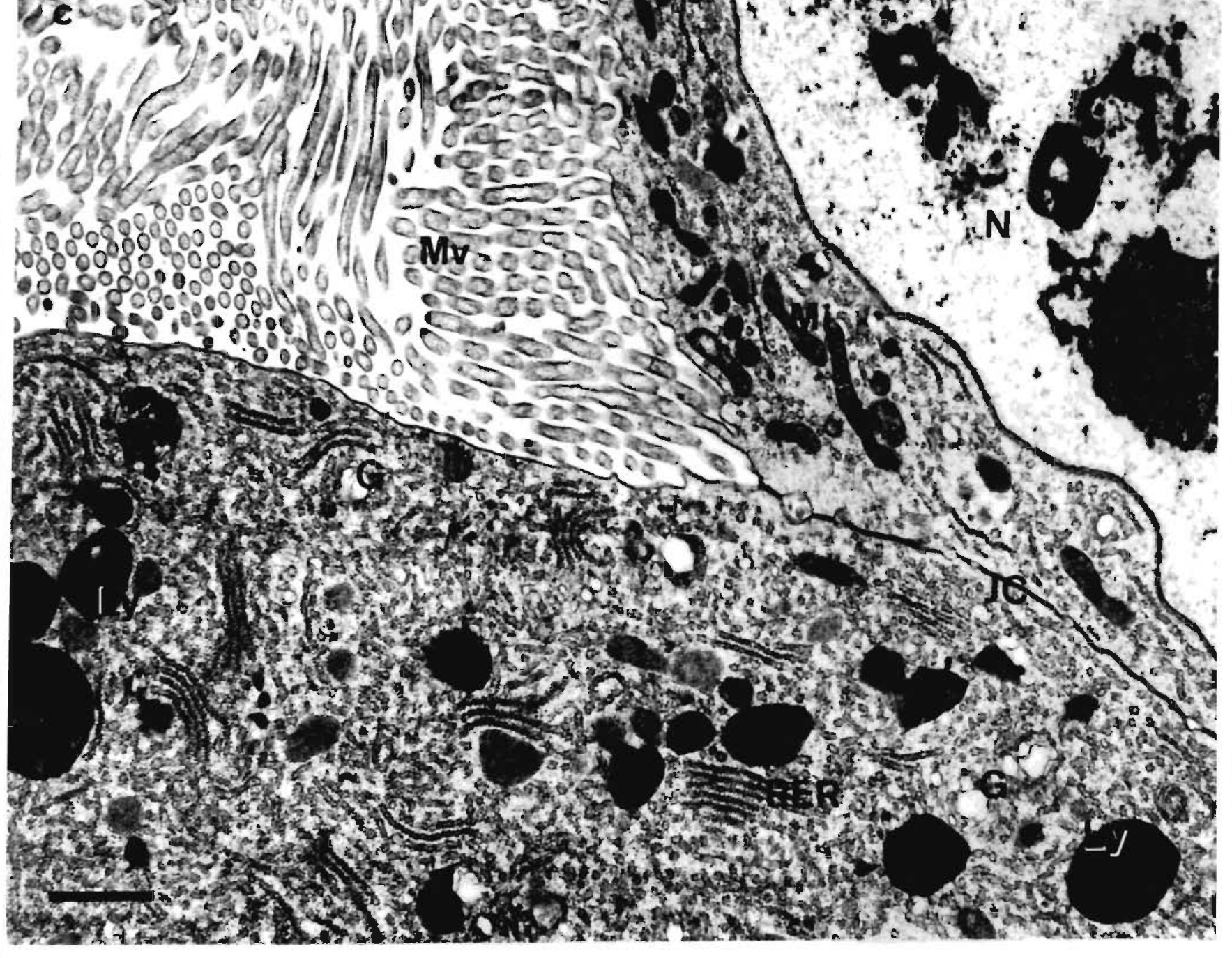


apical, próximo à base das microvilosidades (Fig. 5a).

Esferas contendo lipídeos, que estão frequentemente associadas a mitocôndrias, aparecem dispersas no citoplasma, embora predominem no citoplasma apical. Nessas células, o retículo endo plasmático rugoso é abundante e ocorre em grupos de cisternas alon gadas, usualmente dispostas em arranjos paralelos (Fig. 5c). Ele mentos do aparelho de Golgi estão dispersos principalmente no citoplasma apical, na forma de pequenos grupos de cisternas dilatadas e vesículas associadas a essas cisternas (Fig. 5c).

As cēlulas também apresentam alguns lisossomos, micro tūbulos dispersos irregularmente e um grande núcleo apical.

\subsection{Ultraestrutura das células do ventrículo}

As células do ventrículo anterior, com exceção das célu las regenerativas, são caracterizadas pela presença de microvilosidades curtas (cerca de $0,6 \mu \mathrm{m}$ de comprimento) arranjadas irregularmente na superfície apical (Figs. 6a e b) e por invaginações pronunciadas da membrana plasmática basal (Fig. 6a). Essas inva ginações estão dispostas paralelamente, possuem numerosas mitocôn drias associadas e estendem-se quase até a superfície apical da célula. As invaginações apresentam numerosas aberturas adjacen tes à lâmina basal (Fig. 6c). No citoplasma apical, existem ele mentos do Golgi. organizados como pequenos grupos de cisternas pou co dilatadas, com vesículas associadas e alguns elementos do retí culo endoplasmático (Fig. 6b). Encontram-se ainda no citoplasma esferas lipídicas e numerosos microtübulos irregularmente dispersos.

No ventrículo posterior, as céj.ulas (com exceção das rege nerativas) assemelham-se àquelas dos cecos gāstricos, apresentando na face apical microvilosidades longas (região proximal: cerca 


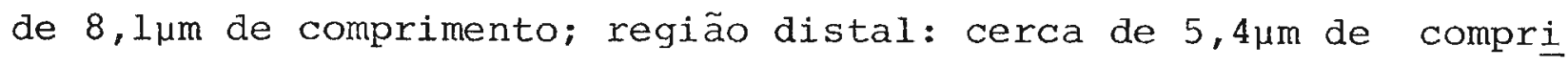
mento) e invaginações da membrana plasmātica basal moderadamente desenvolvidas, com mitocôndrias associadas e poucas aberturas para o espaço extracelular subjacente (Figs. $7 \mathrm{a}, \mathrm{c}, 8 \mathrm{~b}$ e c). A semelhança entre as células do ventrículc posterior e dos cecos gás tricos é maior quando se considera a regiaâo distal do ventrículo posterior (região com dobramentos). Nessa região, células com mi: crovilosidades muito compridas estão agrupadas em grandes dobra mentos epiteliais formando criptas multicelulares (Fig. 8a). As mitocôndrias e o retículo endoplasmático rugoso ocorrem principal mente na região apical da célula e um grande número de esferas li

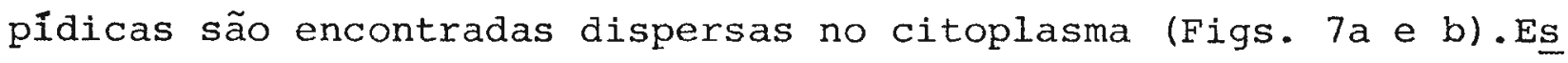
sas observações concordam com resultados anteriores que mostraram que o tubo digestivo é um reservatório de lipídeos (TERRA et.1975) e que esses são armazenados principalmente na região posterior do tubo digestivo (MARQUES, 1976). Entretanto, a distribuição das esferas lipidicas entre as várias células do ventrículo posterior proximal não é uniforme; algumas cēlulas estão repletas de esferas, enquanto outras células apresentam poucas esferas. Esta diferença foi descrita anteriormente utilizando-se métodos histoquí micos e foi usada para apoiar a distinção entre células "digestivas" e "colunares" do ventrículo posterior proximal (MARQuES,1976). Entretanto, com base nos dados de ultraestrutura obtidos aqui, es sa distinção não parece ser justificável. As células do ventrícu 10 posterior apresentam um retículo endoplasmático rugoso moderadamente desenvolvido, elementos do Golgi dispostos principalmente no citoplasma apical e microtúbulos espalhados irregularmente pe lo citoplasma. Entre as microvilosidades, observa-se com frequên cia pequenas depressões que parecem ser internalizadas na forma de vesículas de pinocitose (Figs. 7b, 8b). Lisossomos dispersos no citoplasma são observados somente nas células do ventrículopos terior distal. 
Figura 6 - Ventrículo anterior da larva de R.americana. (a) Aspec to geral de una oélula de ventrículo anterior. (b) Detalhe do ápi re de uma dessas células. (c) Detalhe da base de uma dessas células. As invaginações basais apresentam numerosas aberturas (setas) para o espaço extracelular subjacente. Abreviaturas como na Figu$\underline{\text { ra } 5}$. Baxra $=1 \mu \mathrm{m}$. 

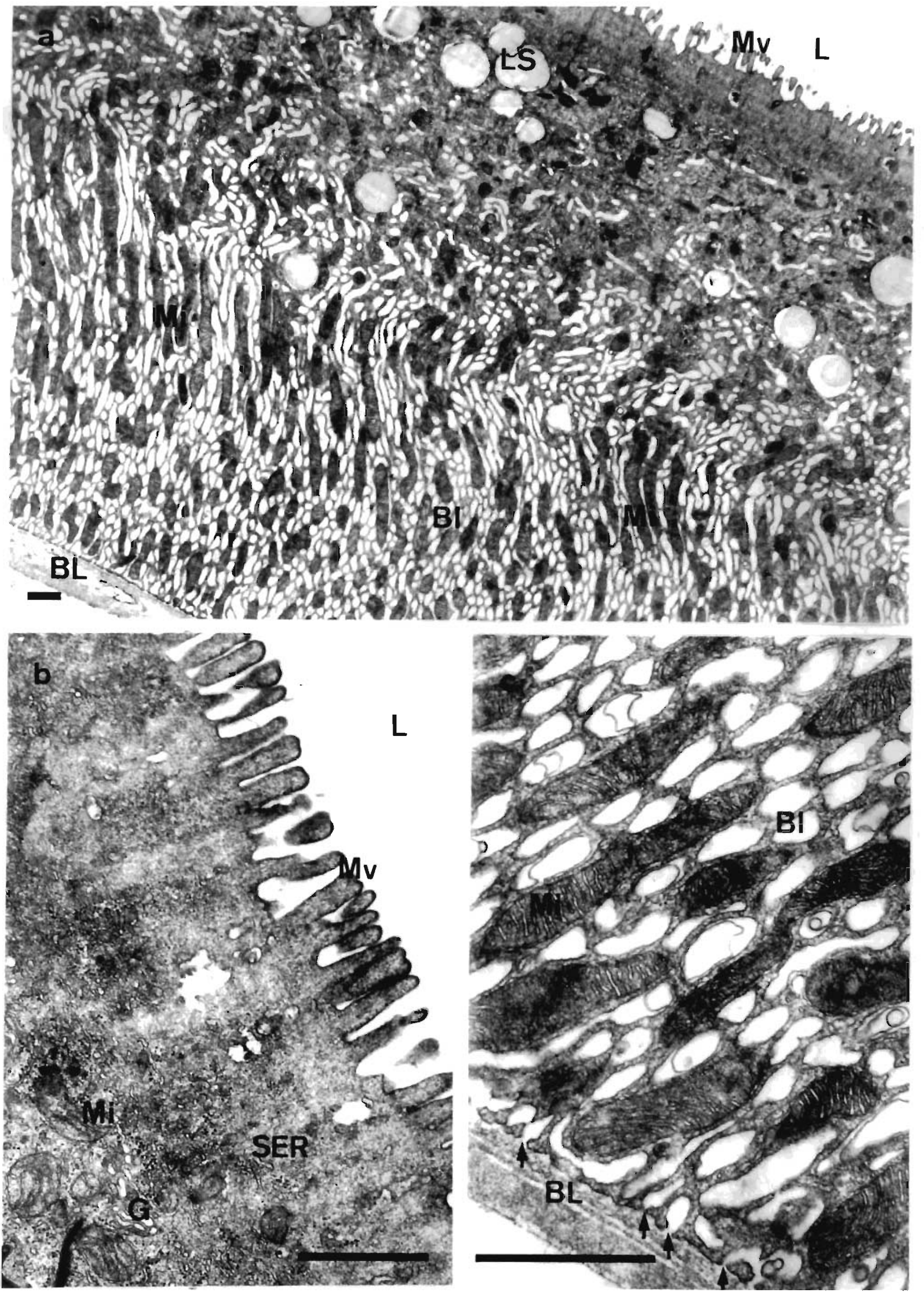
Figura 7 - Ventriculo posterior proximal da larva de $R$.americana. (a) Detalhe do ápice de células do ventrículo posterior proximal mostrando uma cripta entre duas células adjacentes. (b) Detalhe do ápice de uma célula do ventrículo posterior proximal. observam-se vesículas de pinocitose (setas) e um retículo endoplasmáti co rugoso bem desenvolvido. (c) Detalhe da base de uma célula do ventrículo posterior proximal. (d) Detalhe do ápice de uma dessas células. Abreviaturas como na Figura 5. Barra $=1 \mu \mathrm{m}$. 


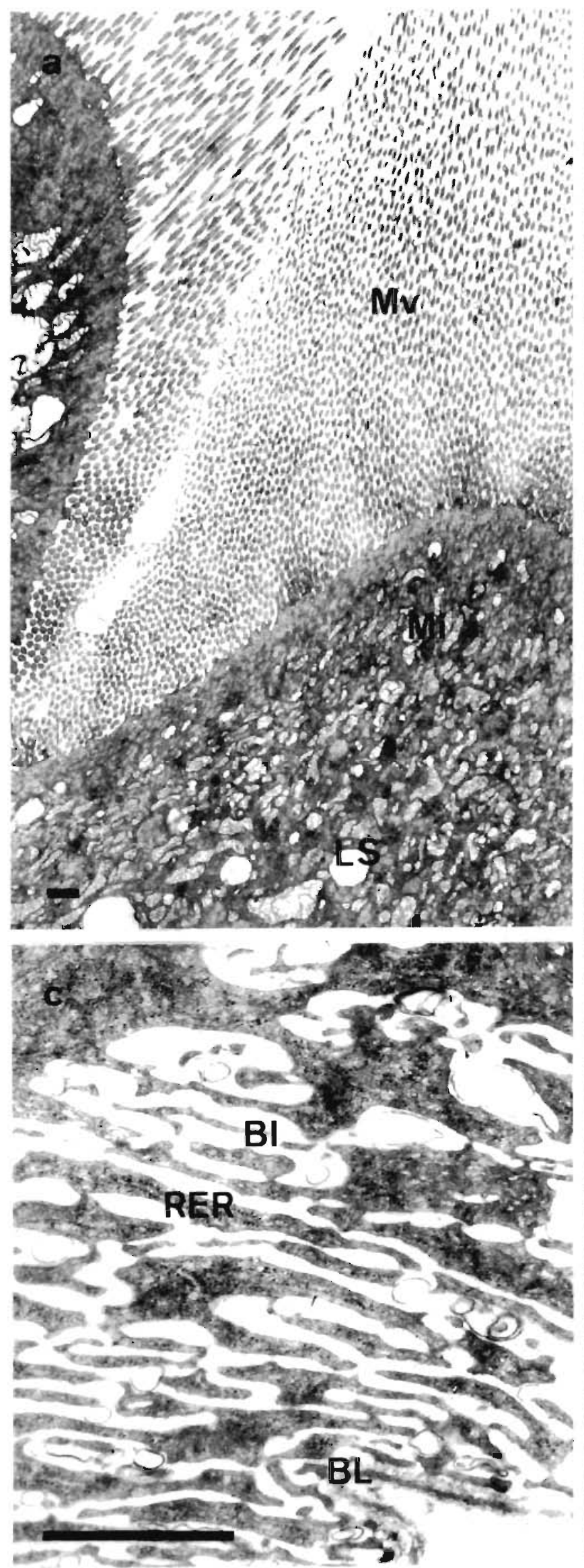

7700

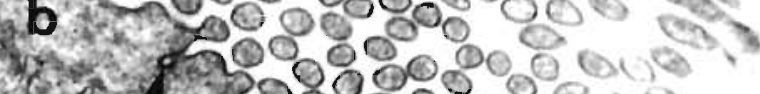

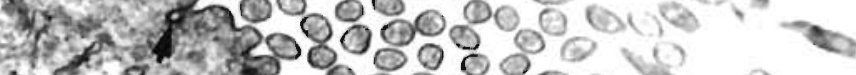

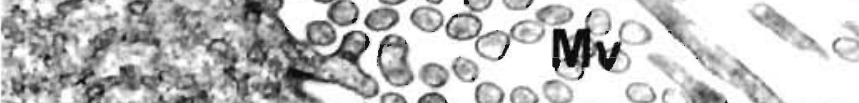

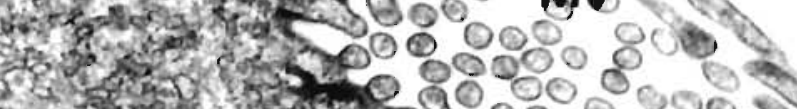

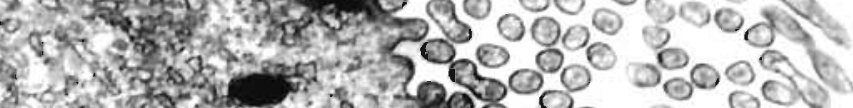
3.

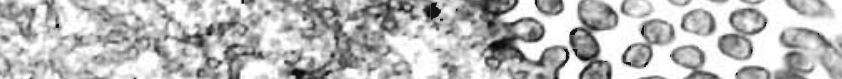

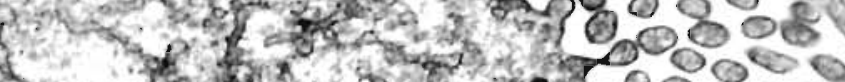

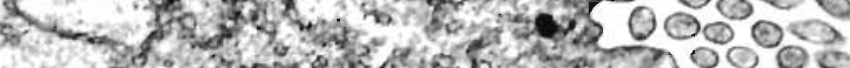

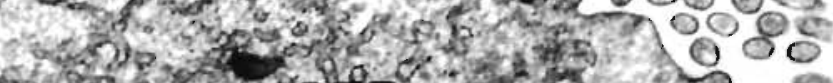

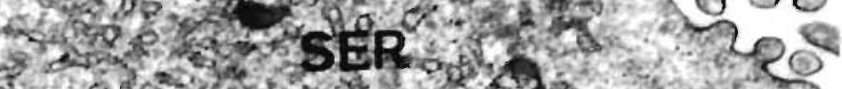

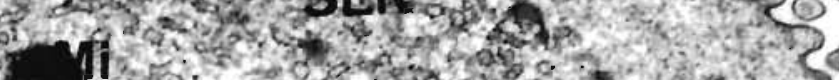

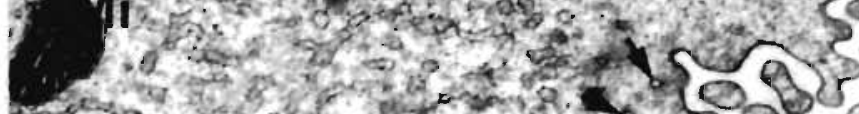



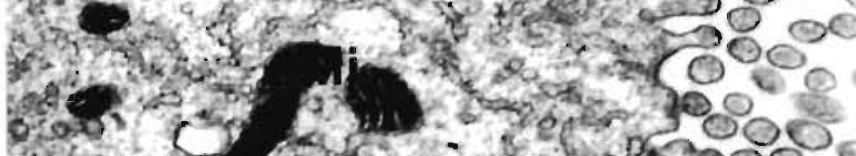




- $x^{2}$.

4 To

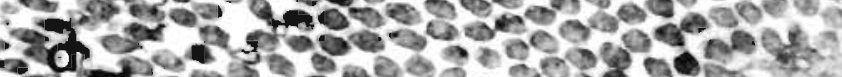
S.

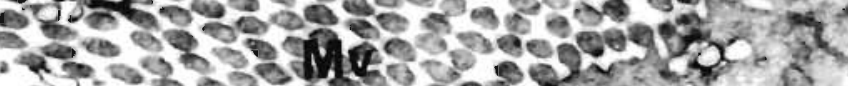



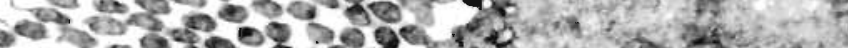

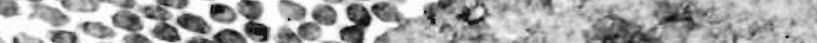

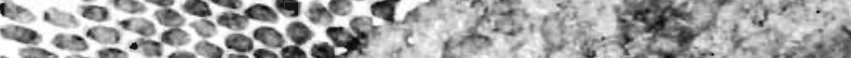

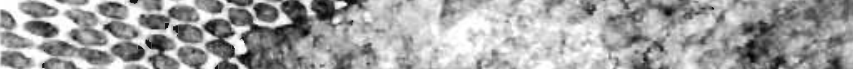

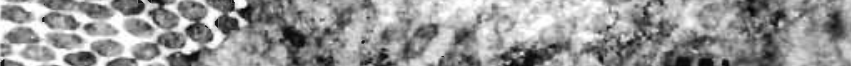

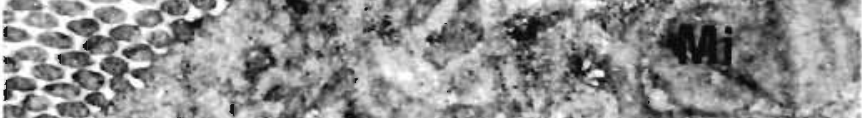

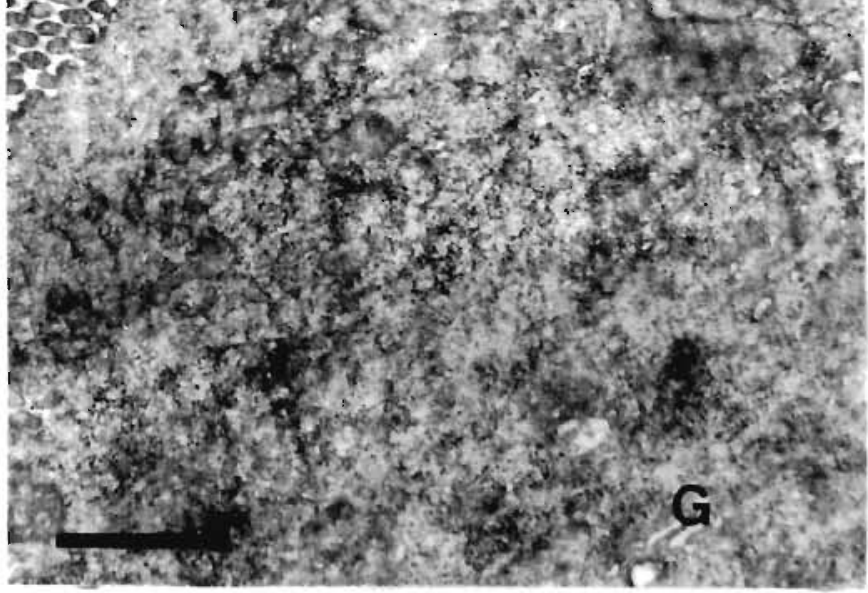


Figura 8 - Ventrículo posterior distal da larva de R. americana. (a) Detalhe do ápice de várias células do ventrículo posterior distal formando uma cripta multicelular. (b) Detalhe do äpice de uma célula do ventrículo posterior distal com uma vesícula pinocítica (seta). (c) Detalhe da base dessas células, onde há poucas aberturas (seta) para o espaço extracelular subjacente. Abreviaturas como na Figura 5. Barra $=1 \mu \mathrm{m}$. 


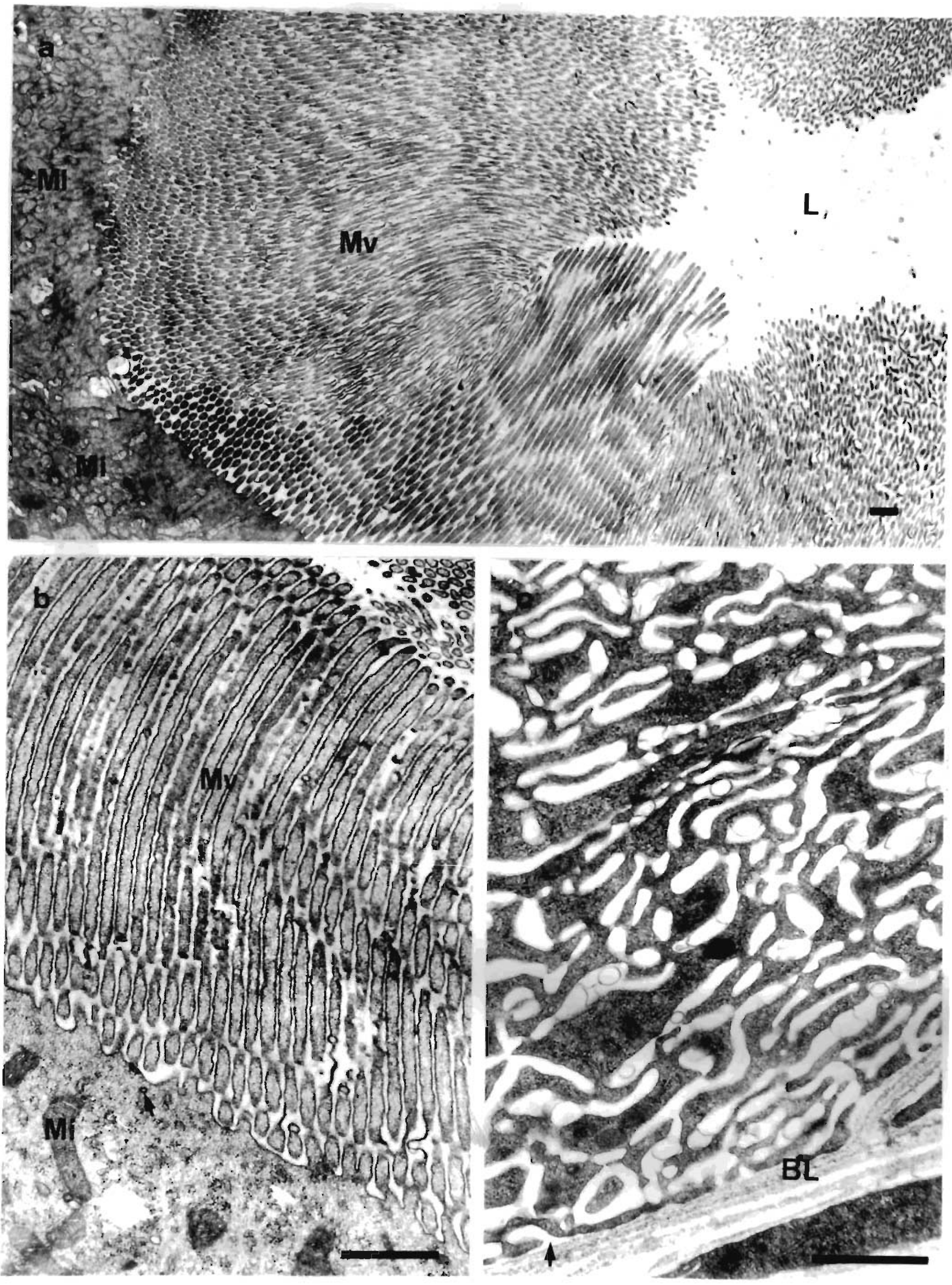


3.6. Enzimas de microvilosidades de diferentes regiões do tubo aigestivo

As recuperações de microvilosidades purificadas em nos sas preparações podem ser calculadas a partir dos dados obtidos para fosfatase alcalina (Tabela V), uma vez que essa enzima ocor re somente na membrana que cobre as microvilosidades das células do tubo digestivo de R. americana (cf. FERREIRA \& TERRA, 1980). A Tabela VI mostra que a quantidade porcentual de proteina celular que ocorre em microvilosidades é semelhante nas células dos cecos e do ven trículo posterior, em contraste com a quantidade muito menor encontrada no ventrículo anterior, mesmo se levarmos em conta as recuperações das diferentes preparações, estimadas a partir dos dados da Tabela $\mathrm{V}$.

As microvilosidades purificadas à partir das diferentes regiões do intestino médio apresentam atividades específicas de 2 a 4 vezes maiores que as do homogeneizado inicial para as carboidrases (com exceção de maltase) e 1 a 1,5 vezes maior para as peptidases e maltase (Tabela VII). O aumento observado naiativi dade específica apoia a suposição de que essas enzimas estão liga das à membrana plasmática, embora a recuperação das atividades na fração de microvilosidades (Tabela VII) demonstre que parte da atividade de peptidase e maltase deve ocorrer em outro lugar.

As microvilosidades das células dos cecos gástricos e do ventrículo posterior são muito semelhantes entre sí e exibem alta atividade especifica para as enzimas digestivas, enquanto que as microvilosidades das células do ventrículo anterior possuem uma quantidade bem menor dessas enzimas (Tabelas VII e VIII). Uma inspeção cuidadosa nas Tabelas VII e VIII mostra que, embora as microvilosidades das células dos cecos gástricos e ventrículo pos terior sejam muito semelhantes, as microvilosidades das células 


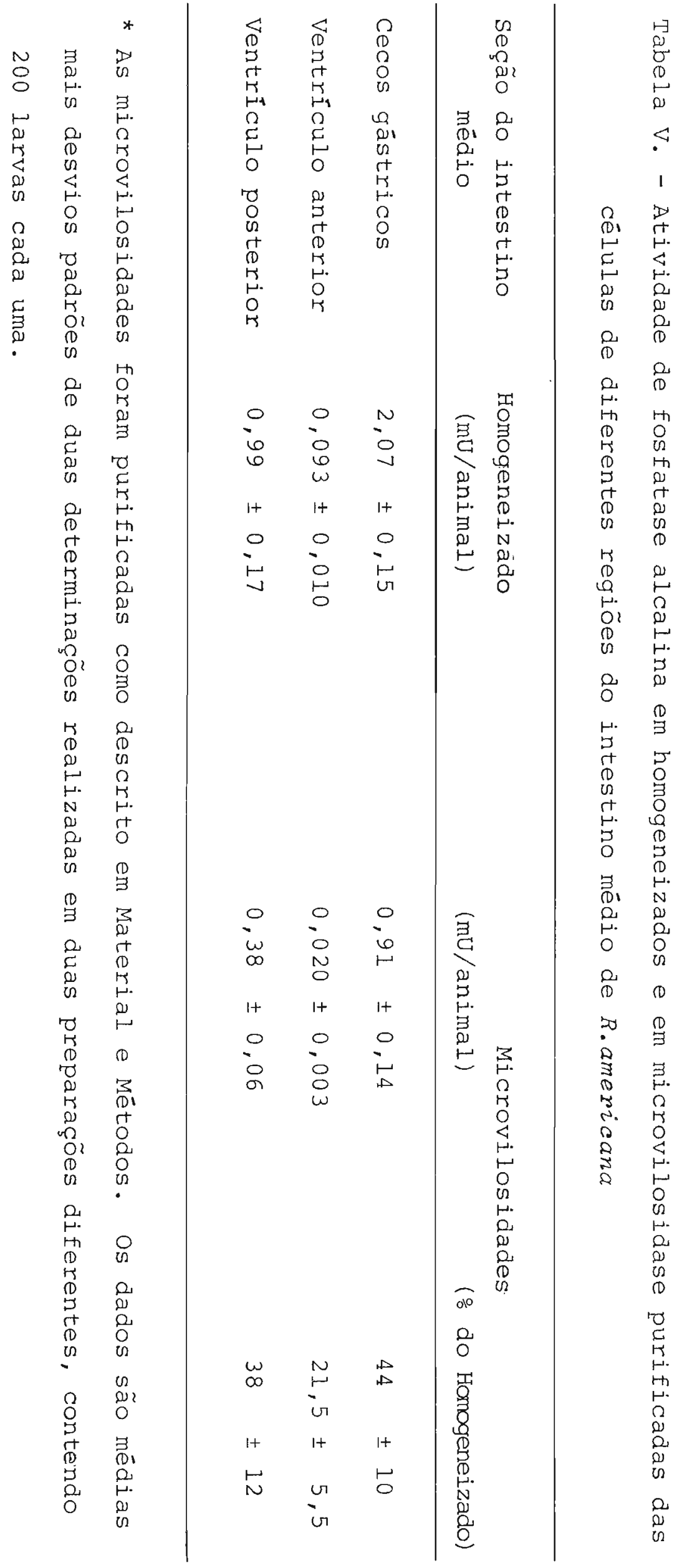




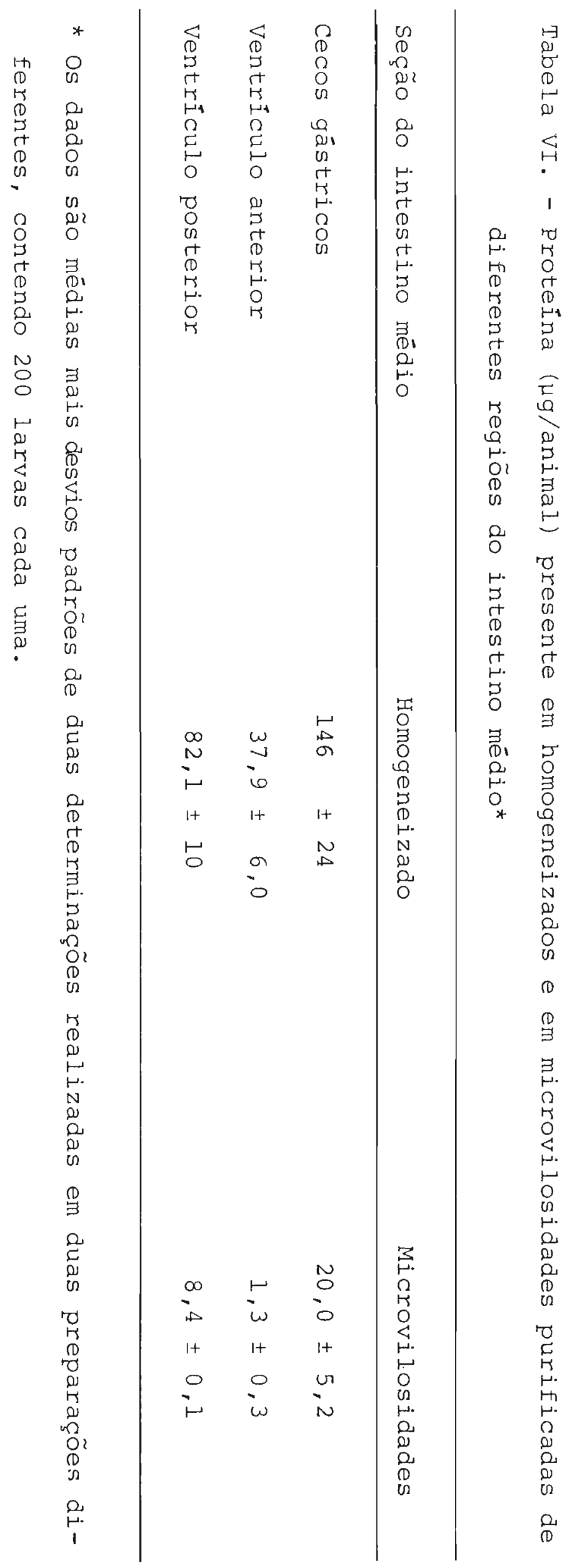




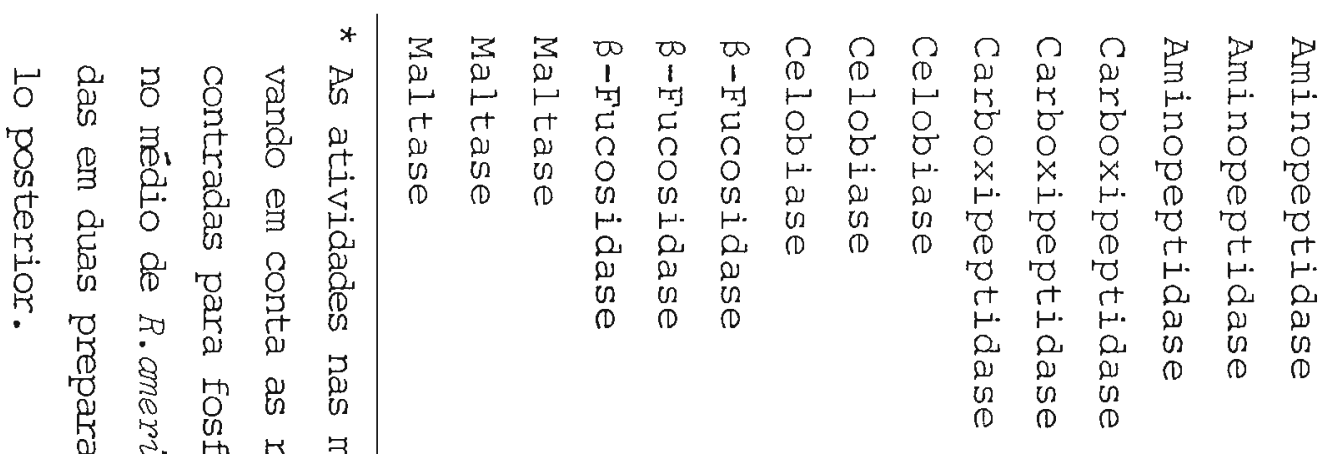

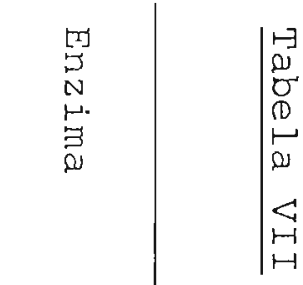

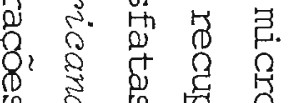

द

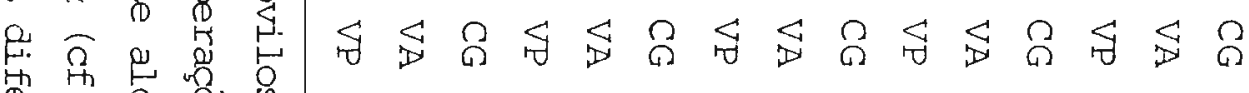

क 0 .

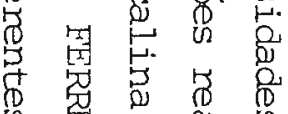

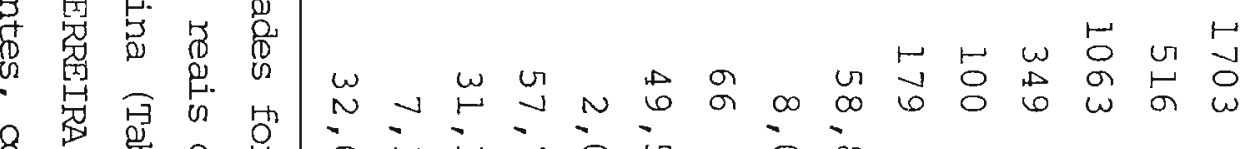

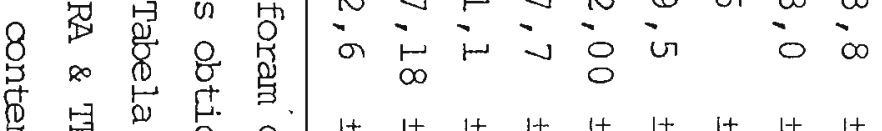

员忽悬

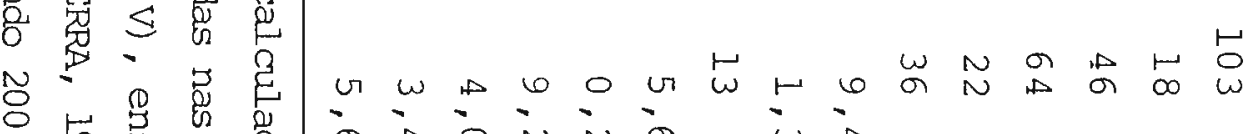

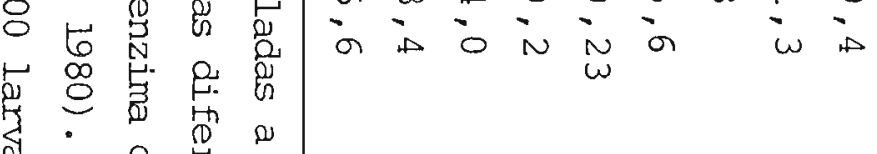

至

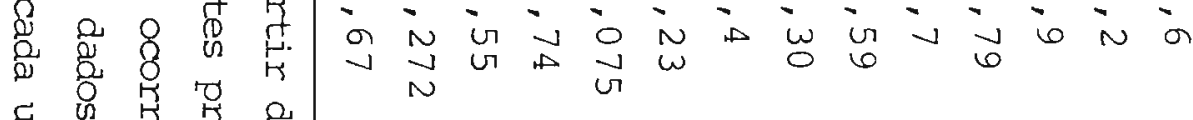

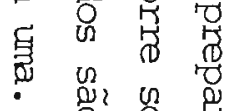

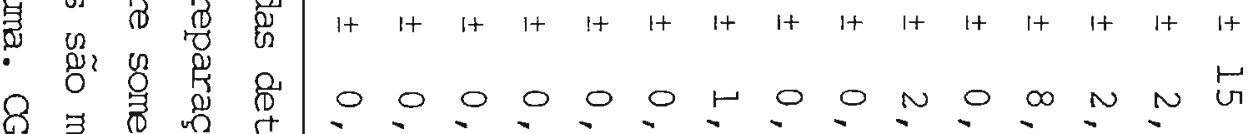

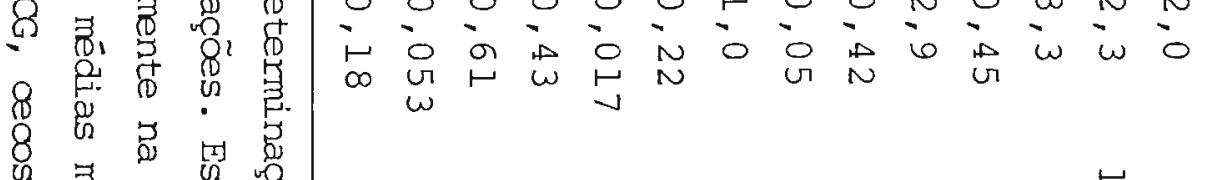

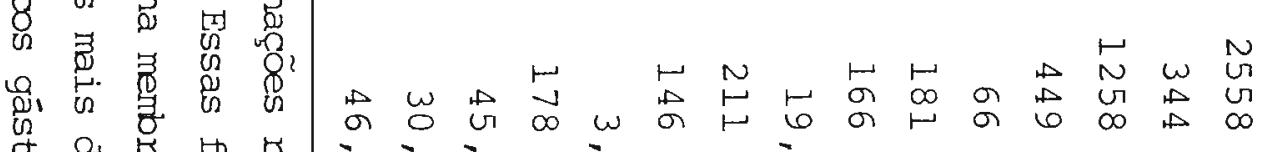

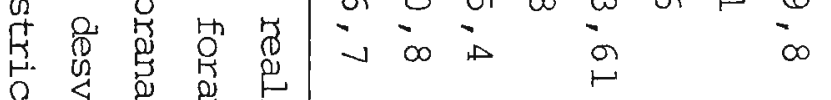

$8 \leftrightharpoons$ ¿

$\therefore$ 只

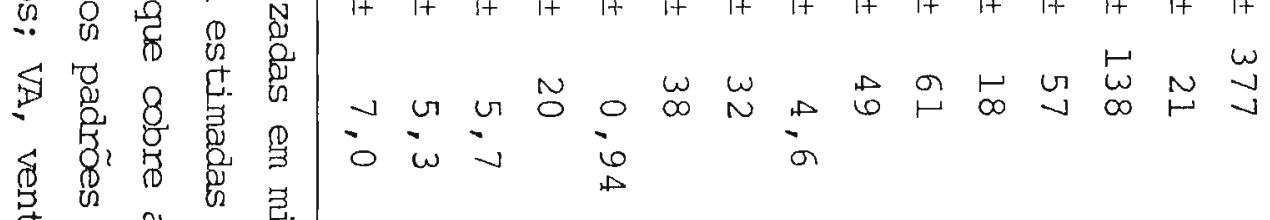

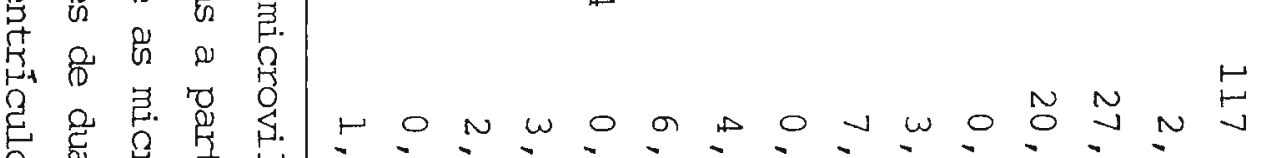

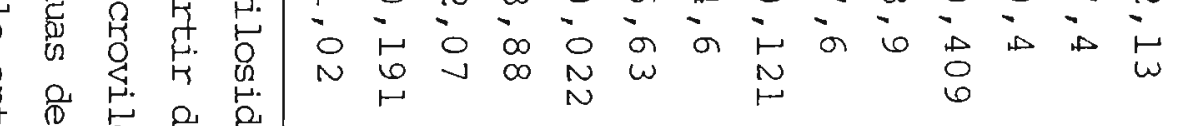

若

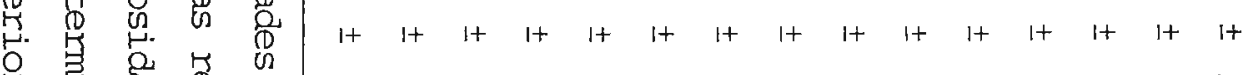

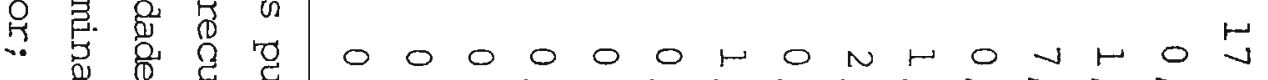

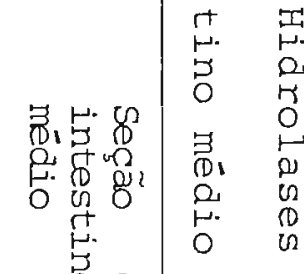

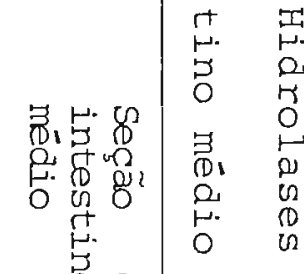



$\begin{array}{lll}0 & 0 & 0 \\ 8 & 0 & 0\end{array}$

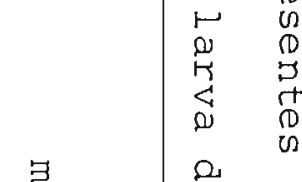

营

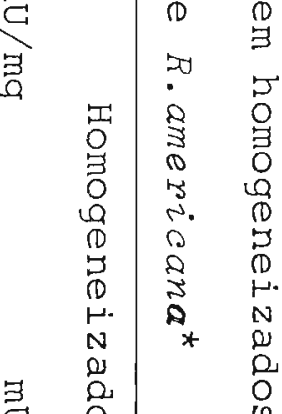

3
0
0
0
0
0
0
0
0
0
$N$
0
0
0
0
0

(1)

$\stackrel{1}{3}$

3

م

¿

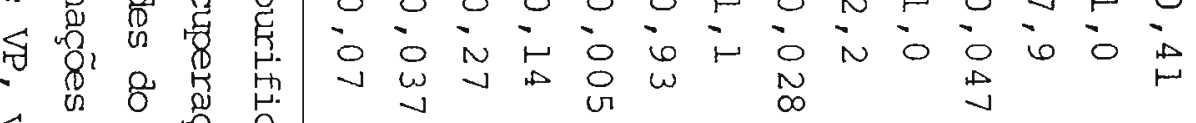

ฐ

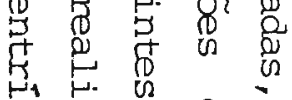

若 


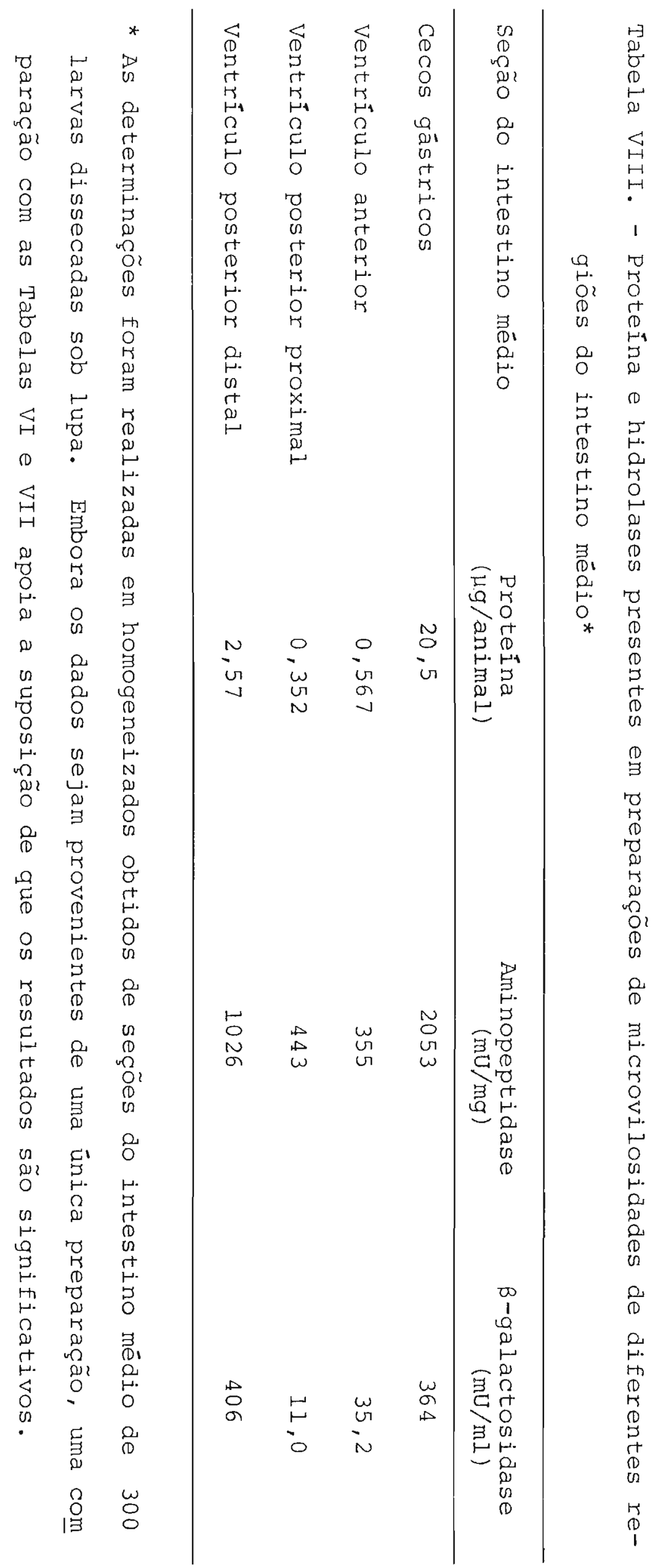


dos cecos são mais ricas em peptidases (aminopeptidase e carboxi peptidase) e mais pobres em oligossacaridases (celobiase, B-galac tosidase e maltase) que as microvilosidades do ventrículo poste rior.

3.7. Solubilização da celobiase por detergentes e por papaína

Cerca de 85\% da atividade originariamente presente na preparação de membranas dos cecos gástricos de R. americana é solu bilizada em Triton X-100. Por outro lado, a papaina é capaz de solubilizar cerca de 75\% da celobiase de membranas, após 45-60 min de tratamento.

Em ambas as solubilizações, a atividade solubilizada so mada com aquela não solubilizada corresponde à cerca de $95 \pm 5 \%$ da atividade encontrada inicialmente na preparação de membranas . Isso significa que a atividade catalítica da enzima não é afetada apreciavelmente por nenhum dos dois processos de solubilização.

3.8. Peso molecular e pI da celobiase solubilizada por detergente e por papaina

Os experimentos de focalização isoelétrica mostraram que existe apenas um pico de atividade sobre celobiose tanto nas preparações em detergente $(\mathrm{pI}=5,4)$, quanto nas preparações com papaina ( $\mathrm{pI}=4,7)$ (Fig. 9). Nos dois casos, a atividade sobre NPBGal parece, coincidir parcialmente com aquela sobre celobiose.

Da mesma forma que no caso da focalização isoelētrica, apenas um pico de atividade sobre celobiose é visivel, nas preparações em detergente e em papaina, após separação em gradiente con tínuo de gilicerol (Fig. 10).

A celobiase solubilizada em detergente apresenta um pe- 

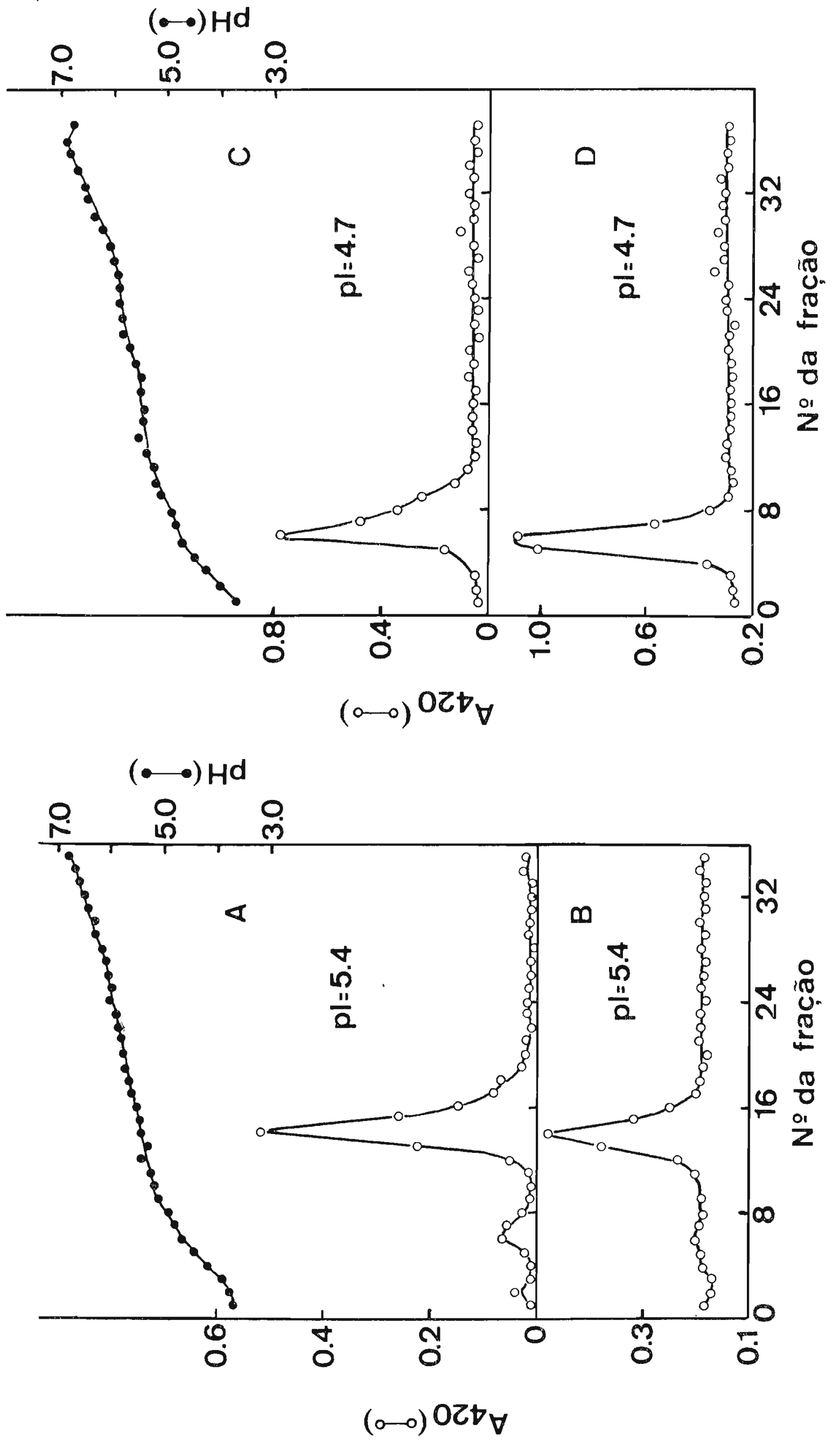

.- 010

$\begin{array}{lll}\text { U } & E & 0 \\ 0 & 0 & \pi\end{array}$

ङ $\begin{gathered}0 \\ -\pi \\ -1\end{gathered}$

$\therefore \stackrel{n}{0} \Sigma$

깅

$\frac{1}{x} \widehat{\theta}$

on

0 ह

$\begin{array}{ccc}+ & 0 & 1 \\ -1 & 0 & 0 \\ -1 & 0 & 0 \\ E-1 & 0 & 0\end{array}$

- $\begin{array}{lll}1 & z & 4 \\ 0 & \equiv & 0\end{array}$

o.

(

$\begin{array}{cc}0 & 0 \\ -7 & 0\end{array}$

N 00

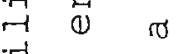

孛 0

$0 \quad+$

थ $\ddot{\sigma}$ б

- E

\begin{tabular}{lll}
0 & 0 & $\Xi$ \\
\hline & 0 & 0
\end{tabular}

年 0

है 4

造吕

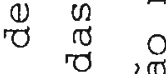

on $\pi$

(1) $N$

त

न 010

म

- $\begin{array}{r}-1 \\ 0\end{array}$

ॠ $\dot{0}$

$\begin{array}{lll}0 & 0 & 0 \\ 0 & 0 & 0\end{array}$

$\begin{array}{ccc}0 & 0 & 0 \\ 0 & 0 & 0 \\ -1 & 0 & 4\end{array}$

मे

(1) 80

๑ E E

U 000

$\begin{array}{rrr}0 & 0 & 0 \\ 10 & -7 & 0 \\ 0 & 0\end{array}$

唡

N

ชั

O 9 .

1 出

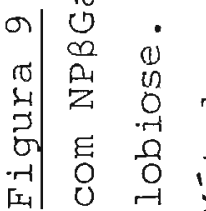



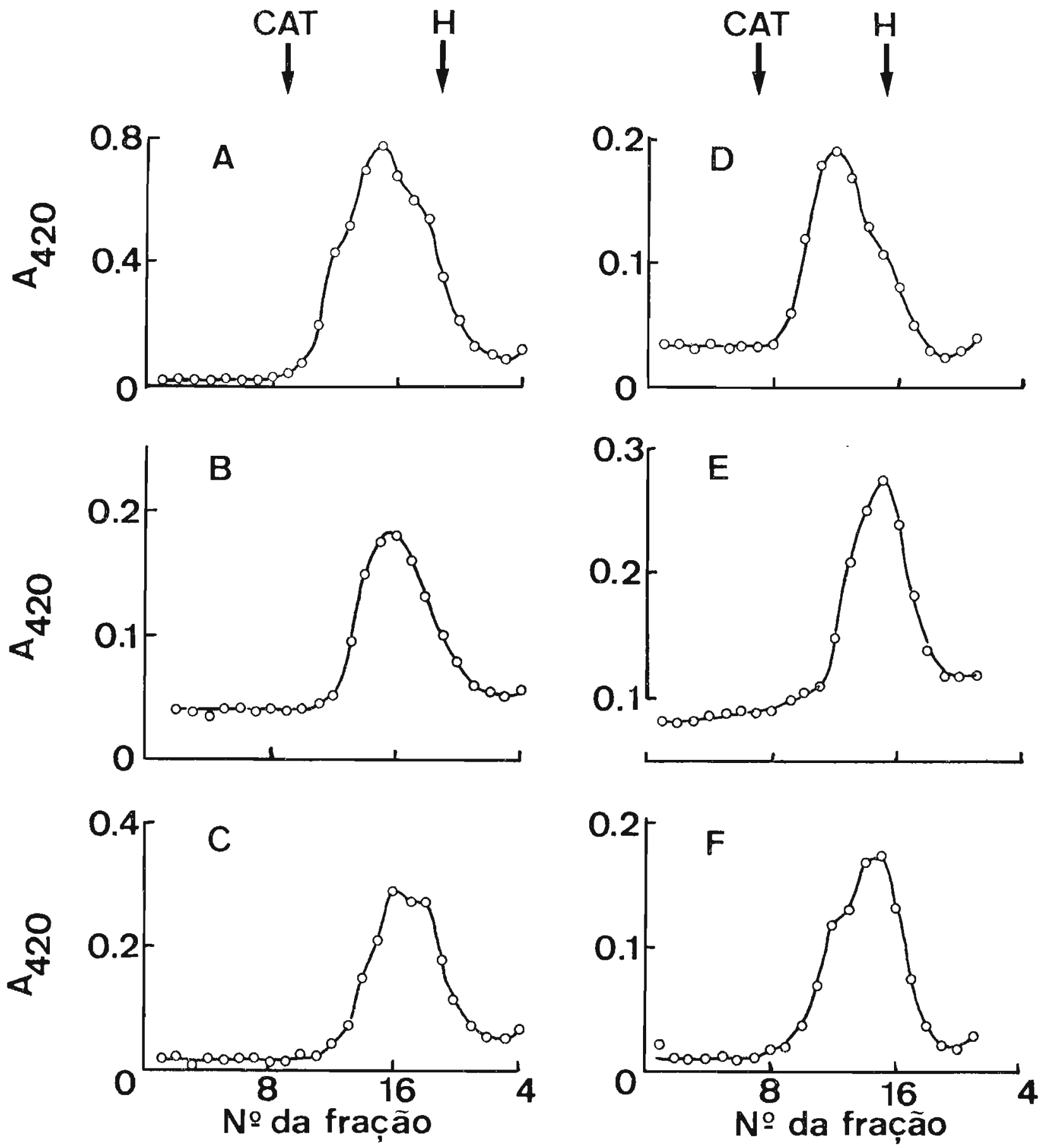

Figura 10 - Perfis de sedimentação, em gradientes contínuos de glicerol, de hidrolases de membranas solubilizadas por Triton $\mathrm{X}-100$ ou pör. papaina. As frações $(0,2 \mathrm{ml})$ foram coletadas a partir do fundo do tubo. Solubilizadas por Triton X-100: (A) ensaio com NPBGal, (B) ensaio com celobiose, (C) ensaio com NPBFuc. Solubilizadas por papaína: ensaio com NPBGal, (E) ensaio com celobiose, (F) ensaio com NPBFuc . Marcadores de peso molecular: CAT, catalase de fígado bovino(PM 232000); H, hemoglobina bovina (PM 64500). Perfis obtidos com outras preparações são muito semelhantes a esses. Ver detalhes em Material e Métodos. 


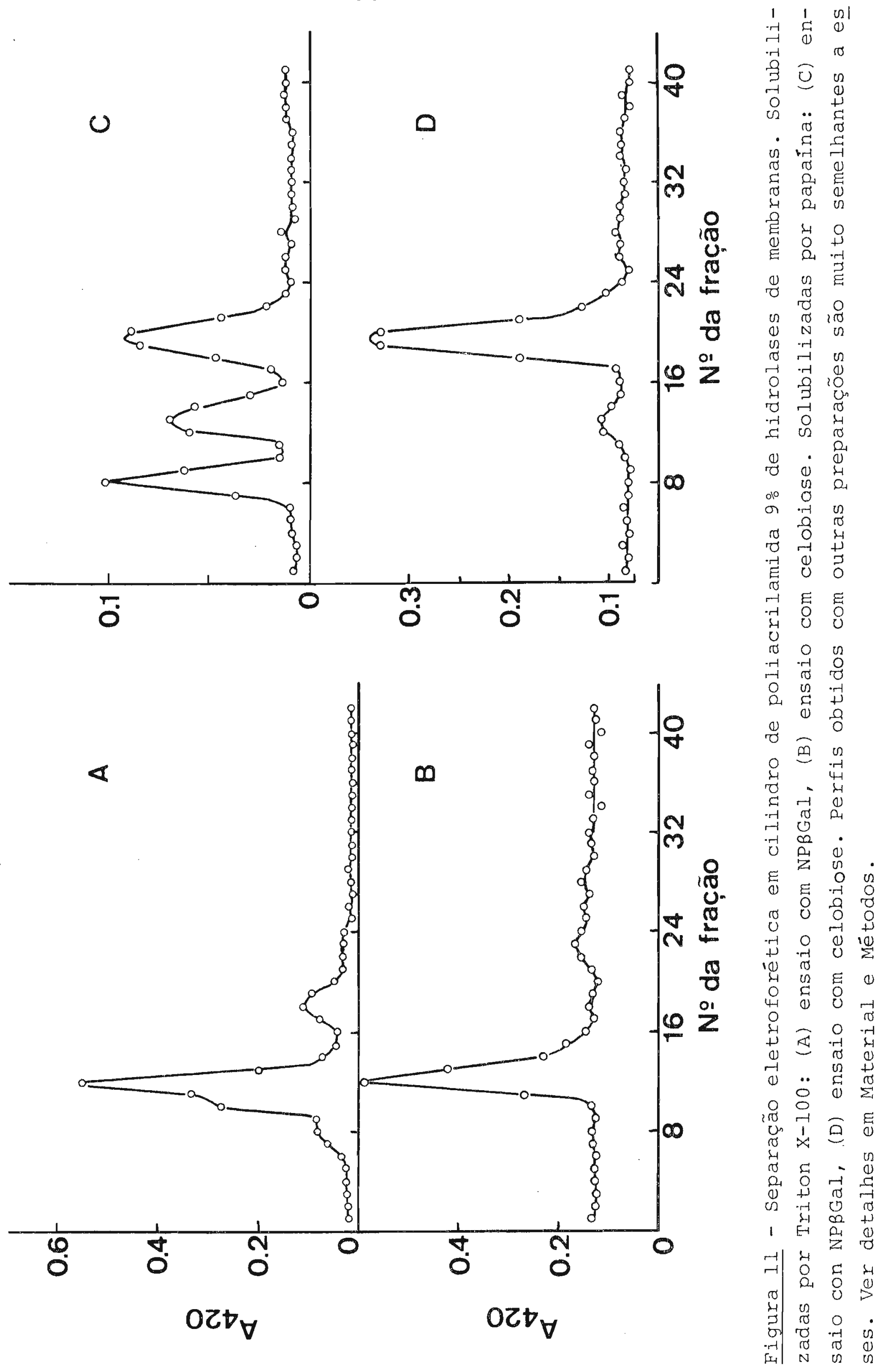


so molecular de $106400 \pm 5600$, enquanto que aquela solubilizada em papaina, $64834 \pm 6000(\mathrm{Fig} \cdot 10)$. Os resultados apresentados nes sa figura mostram ainda que a atividade sobre NPBGal e NPBFuc co incidem parcialmente com aquela sobre celobiase em ambas as prepa rações. Por outro lado, a atividade sobre NPBGli coincide perfe tamente com a sobre celobiose nas duas preparações. Os dados per mitem supor que a enzima responsável pela hidrólise de celobiose e pNPBGli também hidrolisaria NPBGal e NPBFuc, embora outras enzimas tambēm atacariam esses dois ültimos substratos.

Os resultados das eletroforeses de celobiase solubiliza da por detergente e por papaína (Fig. ll) confirmaram as observa ções que indicavam a existência de apenas uma espécie molecular de celobiase e que esta seria responsável por parte da hidrólise de NPBGal.

3.9. Inativação térmica da celobiase solubilizada por detergente e por papaina

A inativação térmica da celobiase solubilizada por detergente e da celobiase solubilizada por papaina seơue uma cinéti ca de primeira ordem aparente por um período de tempo equivalente a pelo menos 3 meias-vidas (Fig. 12). Isso significa que é. muito provável que exista apenas uma espécie molecular de celobiase nas duas preparações. Por outro lado, o fato da meia vida de ina tivação ser praticamente a mesma para as duas espécies de celobia se $\left(t_{1 / 2}\right.$ celobiase em detergente $=17 \mathrm{~min} ; t_{1 / 2}$ celobiase em papaina $=14 \mathrm{~min}$ ) sugere que a papaína não deve ter afetado de forma apreciāvel a reơião da molēcula de celobiase responsável pela catālise. 


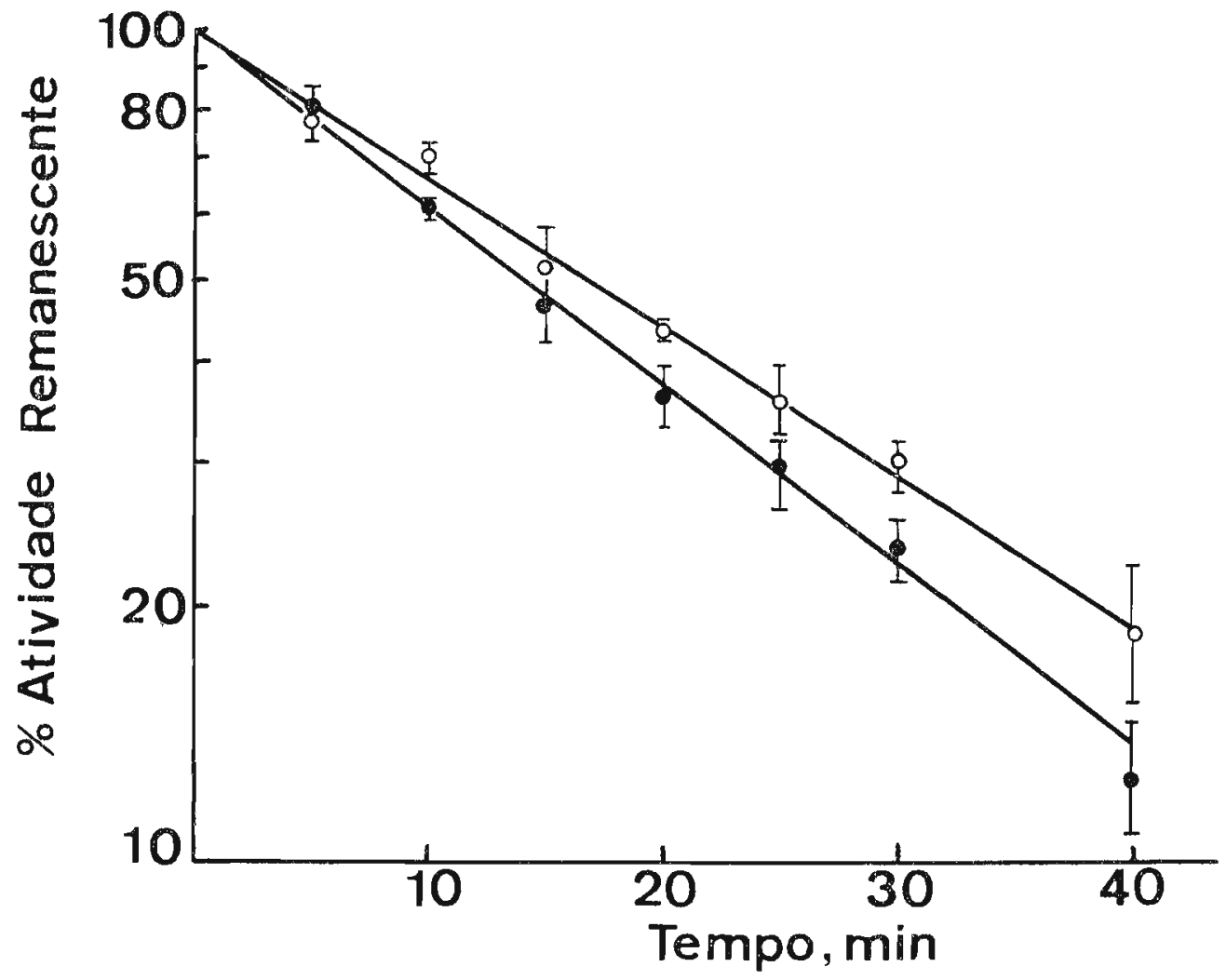

Figura 12 - Inativação térmica da celobiase solubilizada por detergente (o) e por papaina (-) a $50^{\circ} \mathrm{C}$, em tampão fosfato $50 \mathrm{mM}$ pH 6,2. Os resultados são médias mais desvios padrões obtidos em duas determinações independentes. 
3.10. Efeito do pH e da temperatura na celobiase solubilizada por papaína

O efeito do pH sobre a atividade da celobiase sugere a existência de um grupo desprotonado (cujo $\mathrm{pk}_{\mathrm{a}}$ não foi possível de terminar) e um grupo protonado $\left(\mathrm{pk}_{\mathrm{a}} 7,7\right)$ no sitio ativo da forma funcional da enzima, que apresenta um pHōtimo em cerca de pH 6,2 (tampão citrato-fosfato 50mM) (Fig. 13). As descontinuidades das curvas em pH 6,75 correspondem à troca de tampões, devendo ser re putadas a efeitos dos ânions, cátions ou ainda das forças iônicas diferentes dos tampões usados.

Os resultados mostram ainda que $\mathrm{Km}$ é independente de pH ao longo de todo o espectro de pHs. Isso é uma forte evidêncja a indicar que a celobiase opera em equilíbrio rápido e não em estado estacionário (cf. TIPTON \& DIXON, 1979), istoé, a concentra ção do complexo enzima-substrato deve estar em equilïbrio com as concentrações da enzima e do substrato livres.

A energia de ativação da celobiase determinada em condi ções de saturação com o substrato entre 20 e $48^{\circ} \mathrm{C}$ è $12,8 \mathrm{Kcal} / \mathrm{mol}$ (Fig. 14).

3.11. Especificidade de substrato da celobiase purificada

A celobiase foi purificada submetendo-se a enzima solubilizada sob ação da papaina a uma centrifugação em gradiente de densidade. Aliquotas equivalentes às frações 17, 18 e 19 do gradiente E da Fig. 10 de vārios gradientes foram reunidos e usadas como fonte de enzima.

A celobiase purificada hidrolisa B-glicosídeos, B-galac tosideos e $\beta$-fucosídeos (Tabela IX) e não hidrolisa $\alpha$-glicosideos e $\alpha$-galactosideos (Tabela X). 

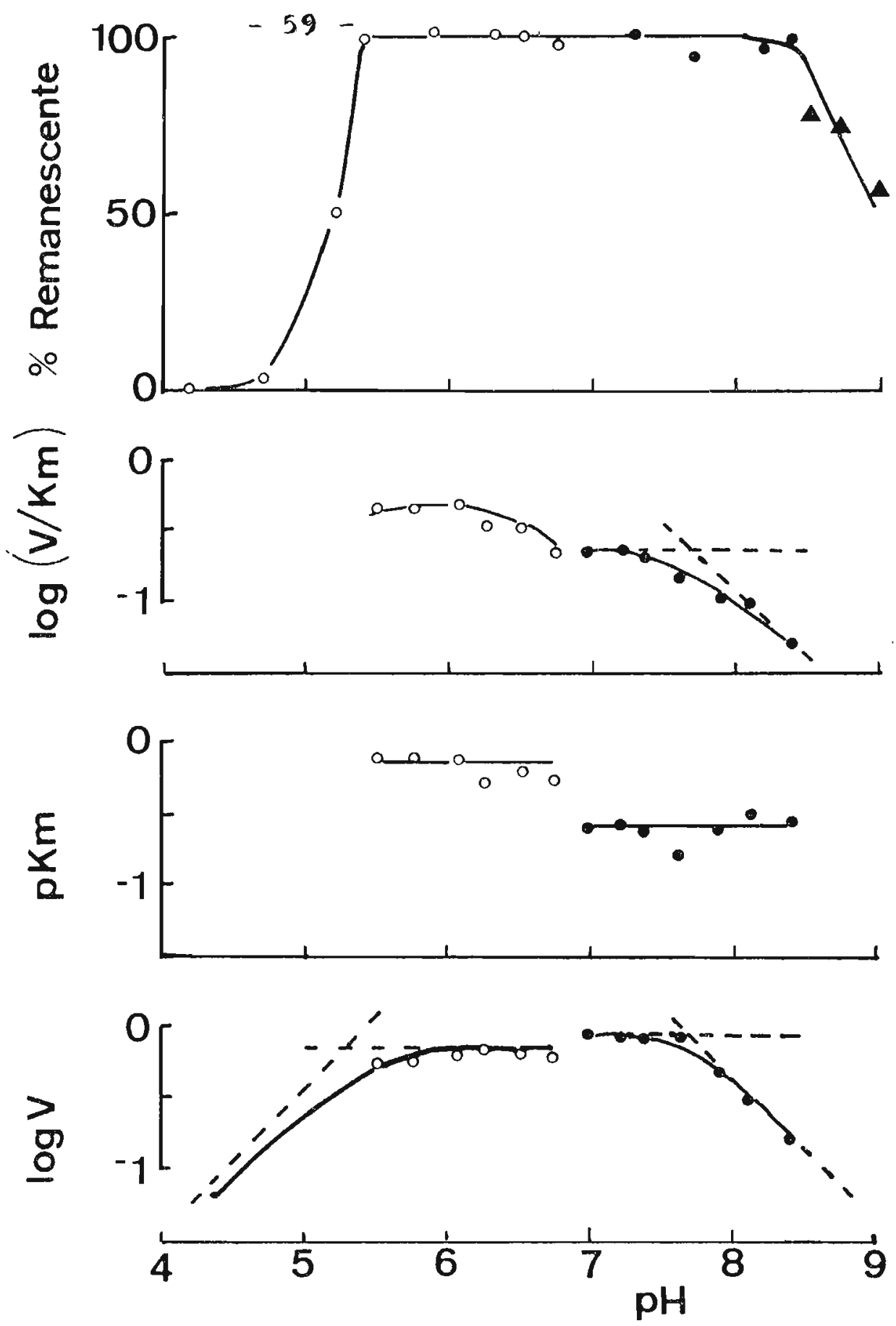

Figura 13 - Efeito do pH sobre a estabilidade e sobre alguns parâ-metros cinéticos da celobiase solubilizada por papaína. As amostras de enzimas foram incubadas a diferentes valores de pH em várias con centrações de celobiose e os $\mathrm{V}$ e $\mathrm{Km}$ aparentes foram extrapolados a partir de plotes de Lineweaver-Burk. Os ensaios foram realizados a $30^{\circ} \mathrm{C}$ em tampões citrato-fosfato $50 \mathrm{mM}$ (o) ou tampões pirofosfato $50 \mathrm{~mm}$ - Para a determinação da estabilidade ao pH, a enzima foi deixada por $2 \mathrm{~h}$ a $30^{\circ} \mathrm{C}$ em tampões de diferentes pHs, antes de ser diluí da 10 vezes pela adição de tampão fosfato 0,IM pH 6,2, seguido por ensaios nessas condições ( 4 , tampão ácido bórico-NaOH , 0,1M). 


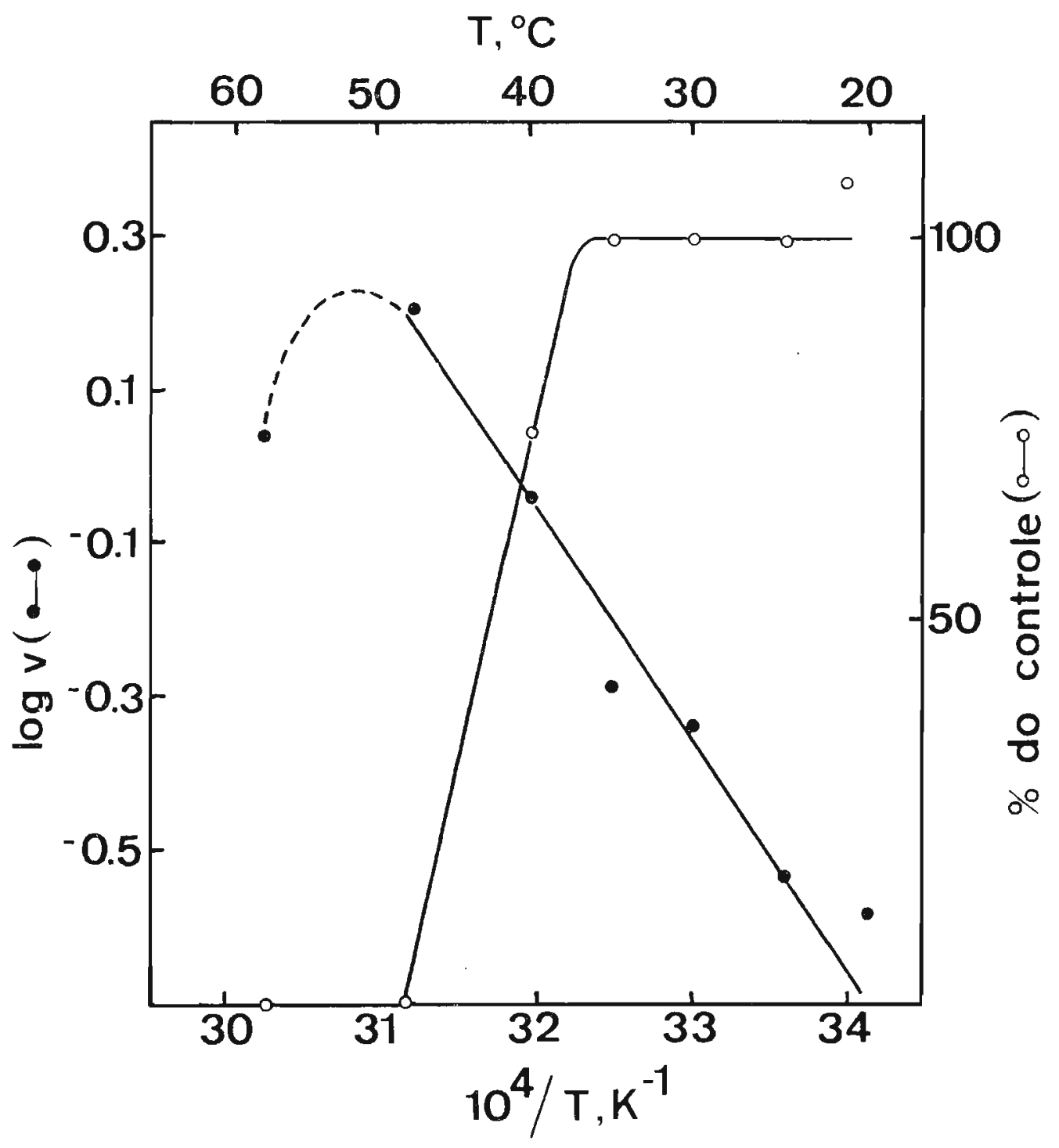

Figura 14 - Efeito da temperatura na atividade e estabilidade da celobiase solubilizada por papaína. A estabilidade térmica foi determinada incubando-se as amostras da enzima em tampão fosfato $\mathrm{pH}$ 6,2 (50mM) em diferentes temperaturas por $2 \mathrm{~h}$ antes de en saiā-las. A linha reta do plote de Arrhenius foi ajustada aos pontos entre 21 e $48^{\circ} \mathrm{C}$. 
Celobiose e pNPBGli são hidrolisados pelo mesmo sitio a tivo, uma vez que pNPBGli é inibidor competitivo linear simples da reação da celobiase sobre celobiose e celobiose é inibidor com petitivo linear simples da reação da celobiase sobre pNPBGli (Fig. 15). Além disso, os valores de $k_{i}$ do pNPBGli $(0,40 \mathrm{mM})$ e $k_{i}$ da ce lobiose $(0,73 \mathrm{mM})$ concordam com os valores de seus respectivos $\mathrm{Km}$ $(0,53$ e $0,61 \mathrm{mM}) \quad($ Tabela IX).

Afim de verificar se um mesmo sitio da celobiase é capaz de hidrolisar $\beta$-glicosideos, B-galactosídeos e $\beta$-fucosideos ou se, alternativamente, esses diferentes substratos são hidrolisados por sitios ou enzimas diferentes, estudos foram realizados usando um método que envolve a competição entre dois substratos.

Se uma enzima for ensaiada na presença de dois substratos competitivos (isto é, um mesmo sitio for capaz de hidrolisar os dois substratos), a atividade sobre cada substrato na mistura será menor do que a obtida para cada substrato testado separadamente. A velocidade da reação de uma enzima com um sítio capaz de hidrolisar dois substratos será dada pela equação (deduzida as sumindo condições de equilíbrio rápido, cf. SEGEL, 1975):

$$
\mathrm{v}=\frac{\mathrm{v}_{\mathrm{a}}[\mathrm{a}]}{\mathrm{K}_{\mathrm{a}}\left(\mathrm{I}+\frac{[\mathrm{b}]}{\mathrm{K}_{\mathrm{b}}}\right)+[\mathrm{a}]}+\frac{\mathrm{v}_{\mathrm{b}}[\mathrm{b}]}{\mathrm{K}_{\mathrm{b}}\left(1+\frac{[\mathrm{a}]}{\mathrm{K}_{\mathrm{a}}}\right)+[\mathrm{b}]}
$$

onde $v$ é a velocidade da reação na presença de dois substratos (a e b), $v_{a}$ e $v_{b}$ são as velocidades máximas dos dois substratos e $\mathrm{K}_{\mathrm{a}}$ e $\mathrm{K}_{\mathrm{b}}$ são as respectivas constantes de Michaelis.

A velocidade da reação de duas enzimas, cada uma catalisan do a hidrólise de um substrato diferente, será dada pela equação: 
Tabela IX. - Especificidade de substrato da celobiase purificada de cecos gástricos*

\begin{tabular}{lccc}
\hline Substrato & $\begin{array}{c}\mathrm{Km} \\
(\mathrm{mM})\end{array}$ & $\begin{array}{c}\mathrm{V} \\
(\mathrm{nmoles} / \mathrm{min})\end{array}$ & $\mathrm{V} / \mathrm{Km}$ \\
\hline Celobiase & $0,61 \pm 0,08$ & $1,51 \pm 0,04$ & $2,48 \pm 0,39$ \\
ONPBGIi & $0,90 \pm 0,17$ & $2,75 \pm 0,15$ & $3,06 \pm 0,74$ \\
pNPBGli & $0,53 \pm 0,09$ & $1,00 \pm 0,04$ & $1,89 \pm 0,39$ \\
pNPBFuc & $0,50 \pm 0,03$ & $1,05 \pm 0,06$ & $2,09 \pm 0,24$ \\
Salicina & $0,80 \pm 0,12$ & $0,25 \pm 0,01$ & $0,31 \pm 0,06$ \\
pNPBGal & $5,3 \pm 0,7$ & $1,50 \pm 0,12$ & $0,28 \pm 0,06$ \\
PBGli & $3,5 \pm 0,5$ & $0,19 \pm 0,01$ & $0,05 \pm 0,01$ \\
\hline
\end{tabular}

* Celobiase purificada (fração 17, 18, 19 do gradiente E, Fig. 10) foi incubada com cinco concentrações diferentes de cada carboi drato listado, em tampão fosfato $50 \mathrm{mM}, \mathrm{pH} 6,2$ a $30^{\circ} \mathrm{C}$. Os parâmetros cinéticos (médias e desvios padrões) foram determinados u sando uma regressão linear ponderada de acordo com WILKINSON (1961), com o auxílio de uma calculadora programável (Texas Instruments TI 59). 
Tabela X. - Inibição por glicosídeos da celobiase purificada dos cecos gästricos*

\begin{tabular}{lccc}
\hline Carboidrato & \% Inibição & Carboidrato & \% Inibição \\
\hline Trealose & 0,0 & NPaGli & $48,6 \pm 3,2$ \\
Melibiose & $20,2 \pm 3,8$ & Sacarose & $51,0 \pm 5,0$ \\
Maltose & $44,8 \pm 7,9$ & & \\
\hline
\end{tabular}

* Celobiase purificada (fração 17, 18, 19 do gradiente E, Fig. 10) foi incubada com cada um dos carboidratos listados ( $15 \mathrm{mM}$ ) com e sem celobiose (3mM) em tampão fosfato $50 \mathrm{mM}, \mathrm{pH} 6,2$ a $30^{\circ} \mathrm{C}$. Nenhum dos carboidratos serviu de substrato para a celobiase ; ao contrário, eles a inibiram em diferentes graus. Os dados são médias mais desvios padrões de três determinações. 
Tabela XI. - Competição entre substratos da celobiase purificada dos cecos gástricos*.

\begin{tabular}{lcccc}
\hline $\begin{array}{c}\text { Substrato a } \\
(10 \mathrm{mM})\end{array}$ & $\begin{array}{c}\text { Substrato } \mathrm{b} \\
(10 \mathrm{mM})\end{array}$ & $\begin{array}{c}\mathrm{v} \text { calculada } \\
\text { (nitio }\end{array}$ & 2 sitios & $\begin{array}{c}\text { voles/min) } \\
\text { (nmoles/min) }\end{array}$ \\
\hline PNPBGli & NPBGal & 0,522 & 0,736 & $0,423 \pm 0,039$ \\
PNPBGIi & NPBFuc & 0,313 & 0,742 & $0,281 \pm 0,007$ \\
\hline
\end{tabular}

* Os substratos a e b foram adicionados juntose incubados com celo biase purificada (frações 17, 18, 19 do gradiente E, Fig. 10) em tampão fosfato $50 \mathrm{mM}, \mathrm{pH} 6,2$ a $30^{\circ} \mathrm{C}$. As v observadas correspon dem às médias e desvios padrões obtidos de 3 determinações independentes. As velocidades para um e dois sitios foram calcula das a partir dos dados da Tabela IX, fazendo uso das equações apresentadas no texto. 


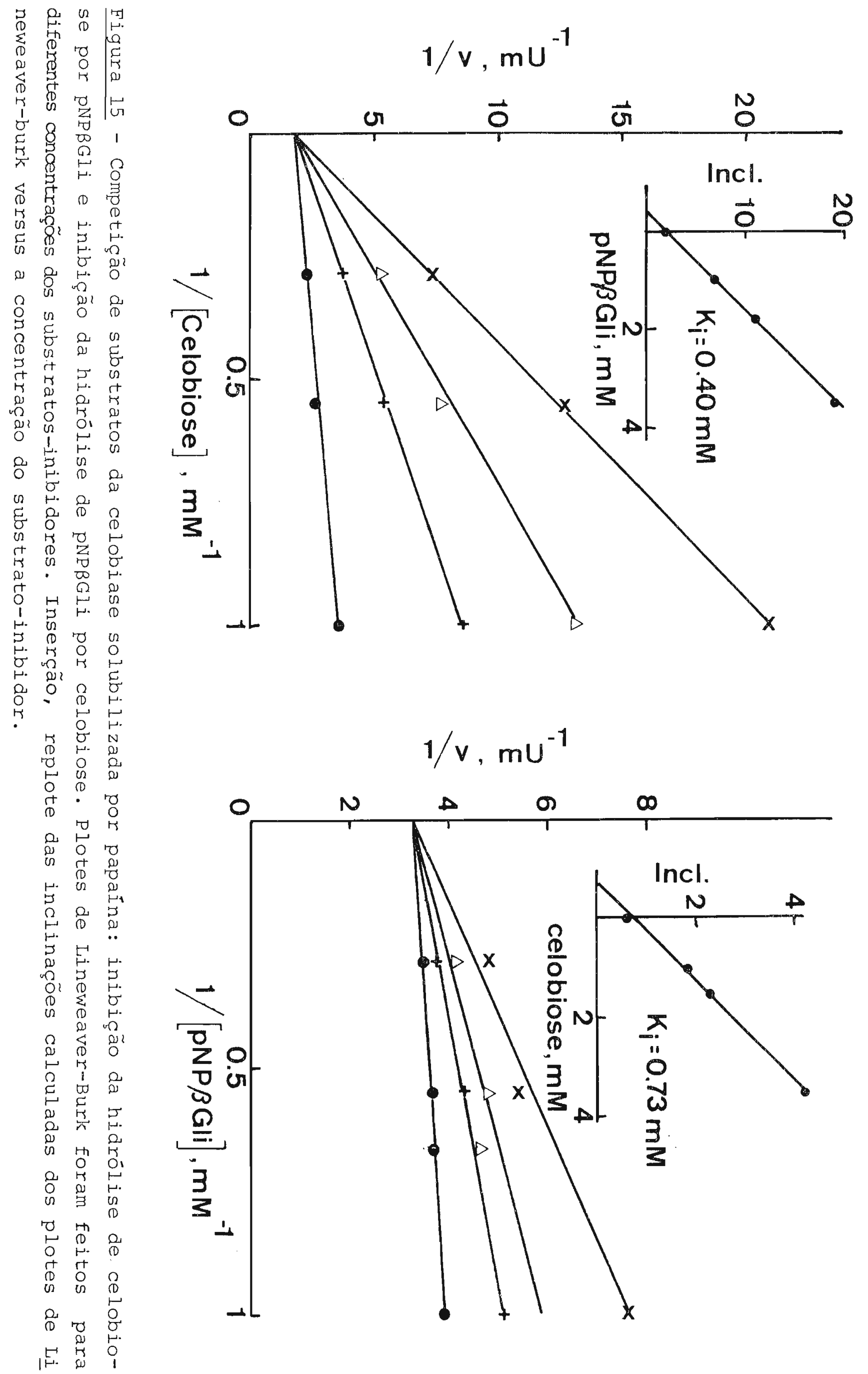

0 告 $\mathrm{s}$

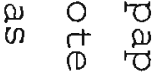

म. थ

$\begin{array}{lll}1 & 0 & 0 \\ 1 & 0 & 0\end{array}$

5

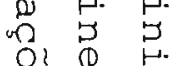

盛 $\sum_{0}$

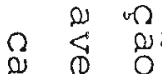

占

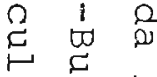

崩点?

吸县

० O O

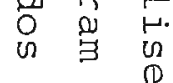

\begin{tabular}{lll}
0 & 1 & 0 \\
\hline & 0 & 0 \\
0 & 0 & 0
\end{tabular}

$\begin{array}{lll}+ & + & \\ \mathbb{D} & 0 & 0 \\ 0 & \Omega & 0\end{array}$

ค.

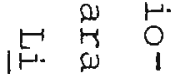




$$
\mathrm{v}=\frac{\mathrm{v}_{\mathrm{a}}[\mathrm{a}]}{\mathrm{K}_{\mathrm{a}}+[\mathrm{a}]}+\frac{\mathrm{v}_{\mathrm{b}}[\mathrm{b}]}{\mathrm{k}_{\mathrm{b}}+[\mathrm{b}]}
$$

onde todos os termos tem o mesmo significado da equação anterior. Os resultados obtidos com celobiase purificada ( Tabela XI ) indicam claramente que ela é capaz de hidrolisar B-glicosí deos, $\beta$-galactosídeos e $\beta$-fucosídeos em um mesmo sitio.

\subsection{Inibição da celobiase solubilizada com papaina por Tris e lactonas}

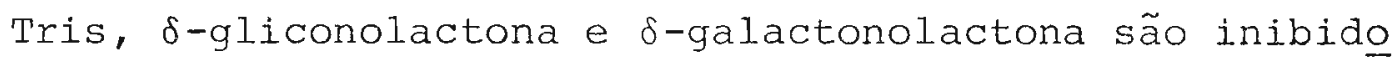
res competitivos lineares simples da celobiase (Fig. 16 e 17) Tris é um mau inibidor $\left(K_{i}=40 \mathrm{mM}\right)$, galactonolactona é um bom in bidor $\left(\mathrm{K}_{i}=0,3 \mathrm{mM}\right)$, enquanto que $\delta$-gliconolatona é um inibidor ex cepcional, cujo $\mathrm{K}_{i}(0,4 \mu \mathrm{M})$ é cerca de 3 ordens de grandeza menor do que o $\mathrm{Km}$ da celobiase para qualquer de seus substratos. Por outro lado, o ácido glicônico não inibe a celobiase mesmo em concentrações 50 vezes maiores $(0,1 \mathrm{mM})$ que as utilizadas com $\delta$-glico nolactona.

3.13. Configuração anomërica da D-glicose liberada pela celobiase solubilizada por papaína

Os resultados apresentados na Fig. 18 mostram que a ce lobiase libera $\beta$-D-glicose, embora eles não possam excluir a pos-

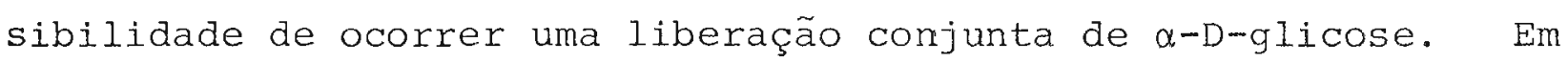
vista disso, pode-se assegurar que a hidrólise catalisada pela celobiase não involve inversão de configuração, embora não se pos sa decidir se a reação ocorre com retenção total ou parcial de configuração. 


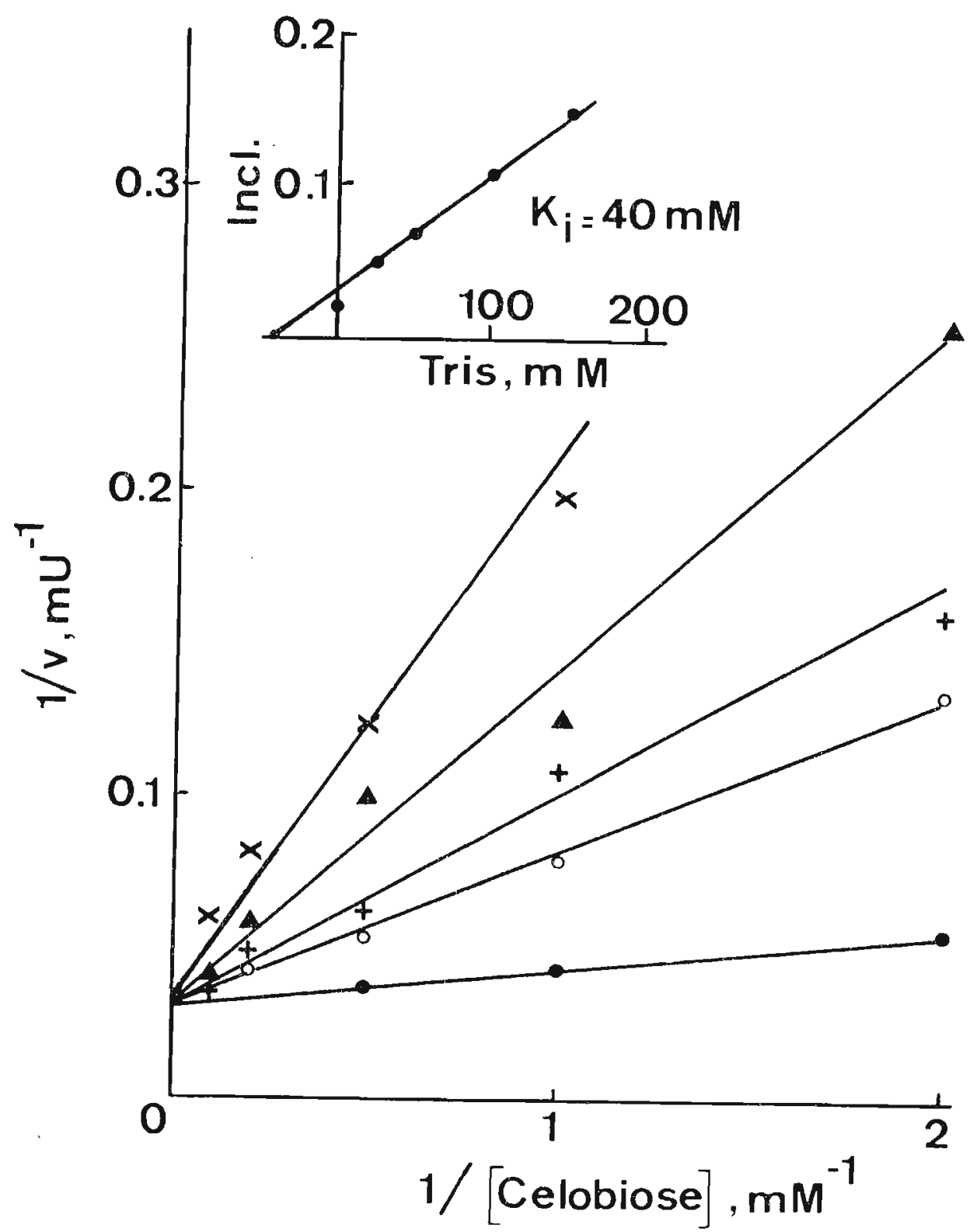

Figura 16 - Inibição por Tris da celobiase solubilizada por papaína. Plotes de Lineweaver-Burk para diferentes concentrações de Tris; inserção, replote das inclinações calculadas dos plotes de Lineweaver-Burk contra a concentração de Tris. A força iônica nos ensaios foi mantida constante $(250 \mathrm{~mm})$ pela adição de quantidades adequadas de $\mathrm{NaCl}$. 


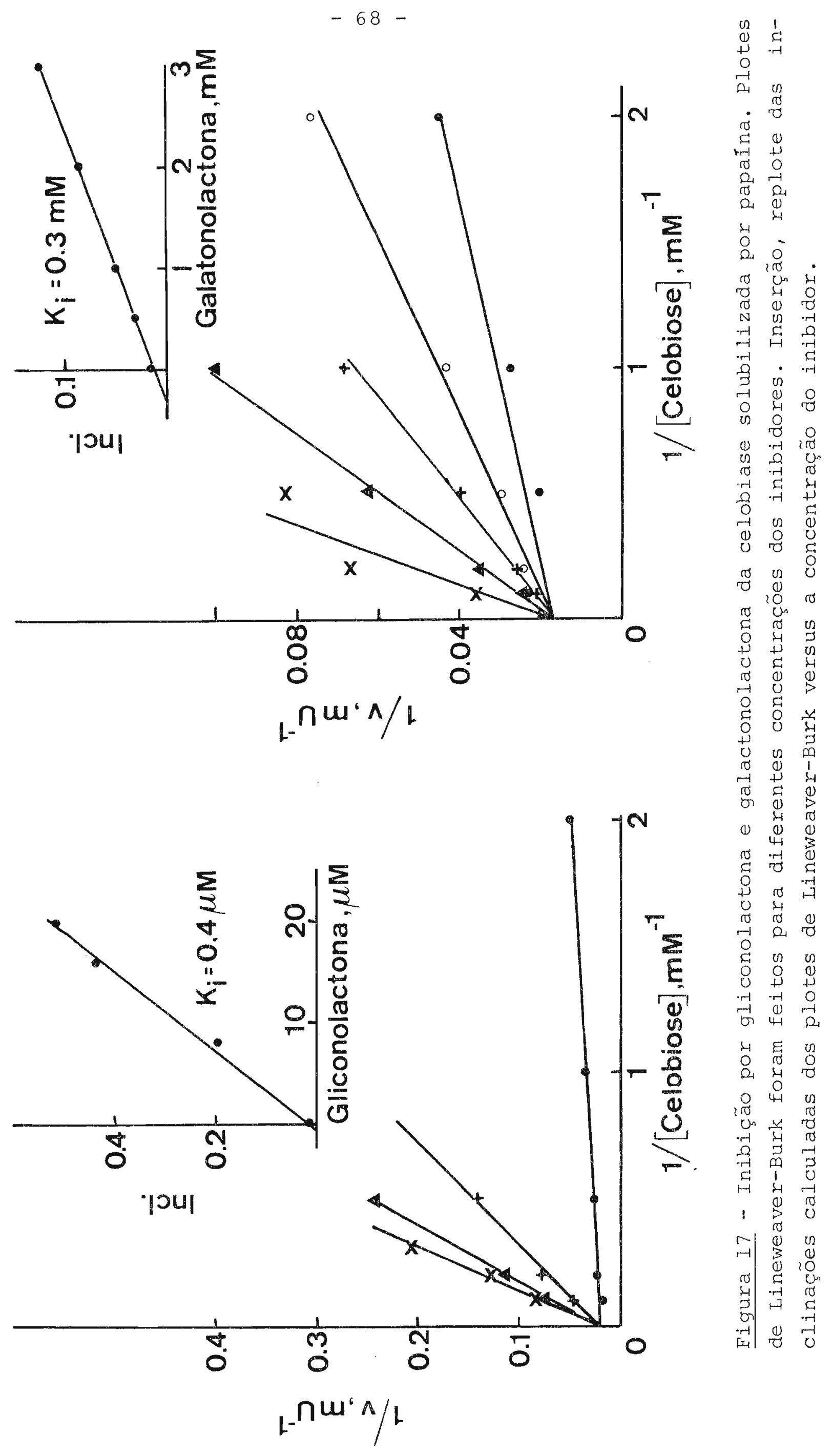




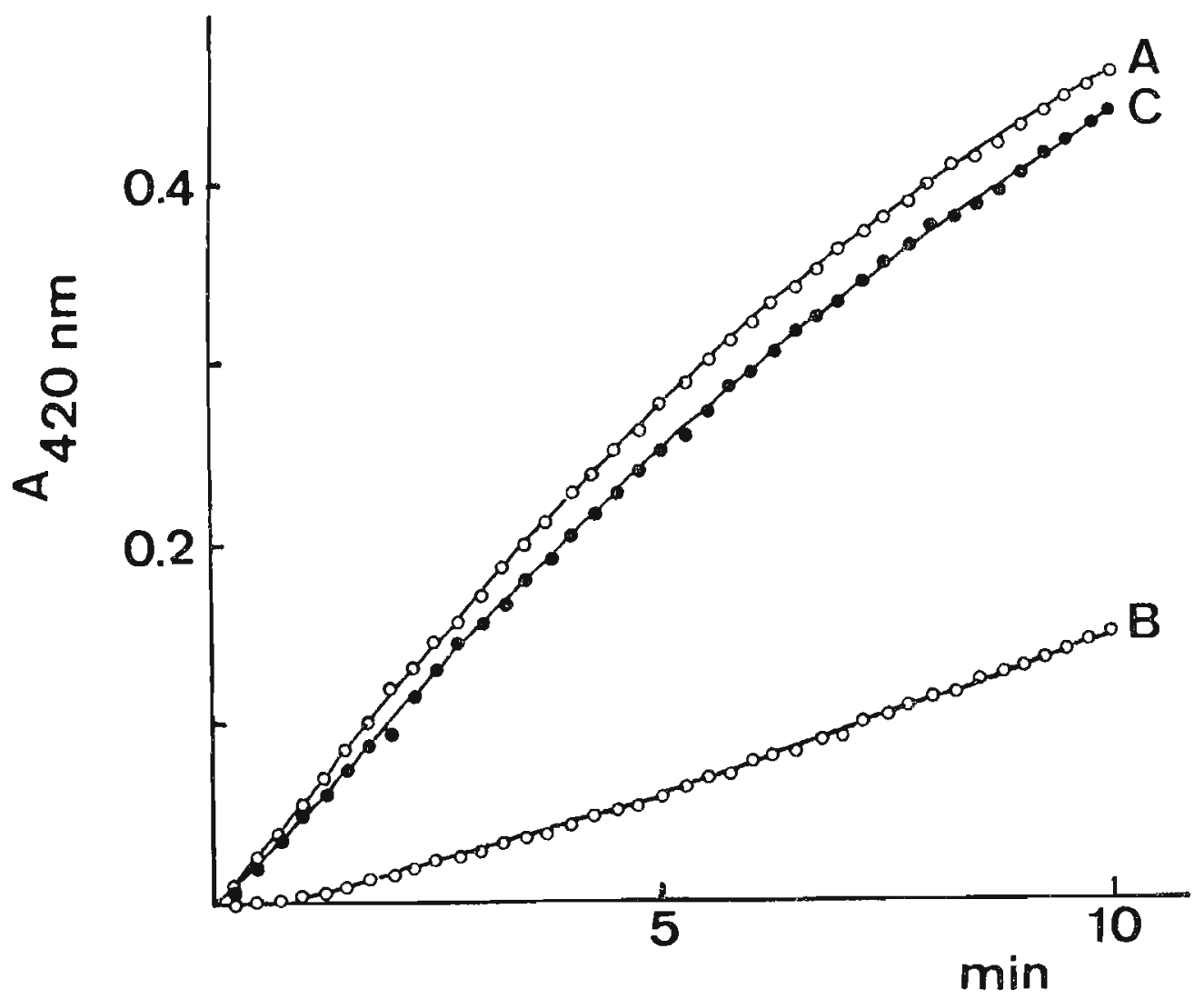

Figura 18 - Identificação enzimātica da configuração anomérica da D-glicose liberada pela celobiase solubilizada por papaina. A, Dglicose liberada pela celobiase. Após a anomerização (obtida por fervura) os resultados obtidos foram idênticos; B, $\alpha$-D-glicose ; C, $\alpha$-D-glicose após anomerização. As concentrações de glicose, e as demais condições experimentais, em B e C são semelhantes ãquelas em A. Ver detalhes em Material e Métodos. 


\section{DISCUSS $\widetilde{A} O$}

4.1. O papel das arilamidases dos cecos de $R$.americana

Nossos dados não são suficientes para afirmar que as arilamidases do intestino médio de $R$. americana são aminopeptida ses verdadeiras. Entretanto, é muito provável que elas o sejam se levarmos em consideração o fato de que todas as arilamidases de intestino médio estudadas até agora são aminopeptidades verdadeiras (WARD, 1975a, b, c; BAKER \& WOO, 1981).

A atividade de arilamidase nas células do ventrículo é baixa (12,3\% da atividade total do intestino médio); a maior par te encontra-se distribuída entre as células dos cecos (do total da atividade do intestino, 24,5\% acha-se nas microvilosidades e 20\% no citossol) e fluido ectoperitrófico (43,2\% do total). (TERRA et a1., 1979; FERREIRA \& TERRA, 1980).

o fluido ectoperitrófico compreende o conteúdo luminal dos cecos e a película de fluido adsorvido externamente à membrana peritrófica (TERRA et al., 1979). O fato de 74,20 da atividade arilamidásica presente no tubo digestivo sex encontrado nos cecos (células e lümen cf. TERRA et al., 1979) sugere que esse ōr gão seja o principal local da digestão intermediária e final de proteínas. Isto provavelmente é consequência do fluxo principal do fluido ectoperitrófico, que vai do ventriculo para os cecos (ver discussão no item 4.4). Esse fluxo carrega os peptídeos pro duzidos pela ação de proteínases sobre as proteinas do alimento, tão logo esses peptídeos tornem-se suficientemente pequenos para atravessar a membrana peritrófica.

As arilamidases do citossol das células dos cecos ( com exceção da arilamidase 5) são encontradas no fluido ectoperitrófi co e sua atividade nas células dos cecos é somente 14,6\% da ativi 
dade presente no tubo digestivo. Os cálculos foram feitos a partir das áreas sob os picos, do perfíl eletroforético apresentado na Fig. 3b, e da atividade relativa encontrada no citossol das cẹ lulas dos cecos. Por outro lado, o conteúdo luminal dos cecos re presenta 43,2\% da atividade total do tubo digestivo. Essas obser vações sugerem que as arilamidases do citossol das células dos cẹ cos são enzimas em via de serem secretadas para o lúmen do tubo digestivo (com exceção da arilamidase 5) e, portanto, não devem ter uma função intracelular. Entretanto, a arilamidase 5, que cor responde a $27 \%$ da atividade arilamidásica do citossol $15,4 \%$ da atividade total do tubo digestivo) e não ocorre no fluido luminal, deve ter uma função intracelular. As arilamidases das microvilosidases dos cecos são muito ativas $(24,5 \%$ da atividade total do tubo digestivo) e são diferentes das arilamidases luminais. E possível que elas tenham especificidades adequadas para completar a hidrólise de peptídeos iniciada pelas aminopeptídases luminais.

\subsection{As células dos cecos gástricos de R.americana}

A existência de um bordo em escova bem desenvolvido e de criptas profundas entre as células dos cecos qaastricos resulta em um enorme aumento da superfície celular voltada para o lúmen. . Esse fato, aliado à presença de grande número de mitocôndrias no citoplasma apical e das invaginações da membrana basal com mito côndrias associadas, pode dar à célula a capacidade de transpor tar vários compostos (THREADGOLD, 1976). Por outro lado, as inva ginações da membrana plasmātica basal delimitam um compartimento extracelular com acesso restrito à hemolinfa (devido a existência de poucas aberturas para o espaço extracelular), o que possibilitaria à celula concentrar solutos nesse compartimento, criando um gradiente de pressão osmótica entre o compartimento e o lúmen, o que pode auxiliar na absorção de água (cf. BERRIDGE, 1970). Um 
compartimento extracelular semelhante, presente no reto de insetos, está envolvido no transporte de água contra um gradiente de pressão osmōtica (cf. BERRIGDE, 1970).

As microvilosidases dos cecos gästricos possuem uma ultraestrutura semelhante a das microvilosidades presentes nor enterocitos de mamiferos. Essas possuem um movimento de sobe e des ce devido ao deslizamento dos seus microfilamentos centrais de ac tina em relação a microfilamentos de miosina presentes no citoplasma apical (MOOSEKER, 1976). Uma vez que hã evidências da ocorrência de actina nos microfilamentos das microvilosidades dos cecos gāstricos de R.americana (FERREIRA, 1979), é possível que essas microvilosidades tenham movimentos similares aos das microvilosidades de enterocitos. As microvilosidades dos cecos gástri cos de $R$.americana e dos enterocitos de mamíferos são semelhantes entre si, não apenas ao nível estrutural, mas também funcionalmen te, pois ambas desempenham papéis similares nos estágios finais da digestão. Assim, os dois tipos de microvilosidades apresentam hi drolases ligadas à membrana plasmática e que estão envolvidas na digestão terminal de carboidratos e proteínas. As diferenças importantes estão restritas à trealase, que é solüvel nesse inseto e ligada a membrana em mamíferos, e à carboxipeptidase, que só ocorre na forma solúvel em mamíferos e aparece solúvel e ligada à membrana em $R$. americana (BARNARD, 1973; FERREIRA \& TERRA, 1980).

4.3. As células do ventrículo anterior e posterior de R. americana

As células do ventrículo anterior apresentam microvilosidades pouco desenvolvidas na face luminal e um sistema de invaginações da membrana basal muito desenvolvido e organizado, com mitocôndrias associadas. Essas invaginações, em contraste com aquelas das células dos cecos, apresentam muitas aberturas dispos 
tas regularmente para o espaço extracelular subjacente, de modo semelhante ao que ocorre em células secretoras de āgua, como as células dos tübulos de Malpighi (BERRIDGE, 1970).

As células do ventrículo posterior, principalmente as da região distal, devem ter funções semelhantes às das células dos cecos gástricos, uma vez que possuem uma ultraestrutura e composi ção enzimática semelhantes. Um outro aspecto em que as células dos cecos gástricos e do ventrículo posterior distal são semelhan tes entre si consiste na sua susceptibilidade a infecção por microsporídeos e por vírus (Prof. A.B. CUNHA, comunicação Pessoal). A despeito da grande semelhança entre esses dois tipos de célu las, algumas diferenças merecem ser mencionadas. Por exemplo, a quantidade de lipídeos e de retículo endoplasmático liso é muito maior nas células do ventrículo posterior do que nas células dos cecos. Éssa observação serve de apoio à suposição de que essas cëlulas sejam o sítio de oxidação de carotenóides. Essa hipōtese é decorrente das observações feitas aqui e de dados anteriores que mostraram que os carotenóides da hemolinfa de $R$. americana são dẹ rivados de $\beta$-caroteno da dieta, que é absorvido, armazenado em gotas de óleo e oxidado no intestino médio, sendo posteriormente ligado a proteína da hemolinfa (TERRA et al., 1980).

Outras diferenças entre as células de ventrículo poste rior e as células do cecos são encontradas nas proporções relativas entre os carboidratos e peptidases presentes nas membranas das suas microvilosidades (ver discussão no ítem 4.4.).

\subsection{Função dos cecos e do ventrículo em R. americana}

Baseando-se na distribuição das enzimas digestivas entre os espaços endo- e ectoperitróficos e células do intestino mé dio, nas taxas de excreção das enzimas que penetram no espaço en- 
doperitrófico e em outros dados, foi proposta a existência de uma circulação endo- ectoperitrófica das enzimas digestivas na larva de R. americana (TERRA \& FERREIRA. 1981, ver também revisão na Introdução). Os dados ultraestruturais e bioquímicos obtidos nesta tese foram combinados em um modelo, mais refinado que o anteri ormente proposto (TERRA \& FERREIRA, 1981), para os fluxos no intestino médio de R. americana (Fig. 19).

Os dados bioquímicos e ultraestruturais obtidos nesta tese e que apoiam o modelo esquematizado na Fig. 19, assim como detalham aspectos específicos, são os sequintes:

a) Uma quantidade muito maior de proteínas (em relação à proteína celular total) é recuperada nas microvilosidades das células dos cecos e ventrículo posterior do que nas microvilosidades das células do ventrículo anterior. Is so concorda com a observação de que os cecos e o ventrículo posterior apresentam células semelhantes com microvilosi dades longas $(3,8$ e $5,4 \mu \mathrm{m}$, respectivamente) e densamente empacotadas, em contraste com as microvilosidades peouenas $(0,6 \mu \mathrm{m})$ e arranjadas irregularmente que são encontradas nas células ventriculares anteriores (ver itens 3.4 e 3.5 ).

b) As microvilosidades purificadas das células do ventrículo anterior e da região proximal do ventrículo posterior apresentam atividades muito baixas de hidrolases de oligômeros, o que sugere fortemente que elas não estão envolvidas na digestão terminal.

c) As microvilosidades purificadas das células dos cecos e do ventrículo posterior possuem alta atividade de hidrolases de oligômeros, o que sugere fortemente seu envolvimento na digestão terminal.

d) As microvilosidades das células do ventrículo pos 


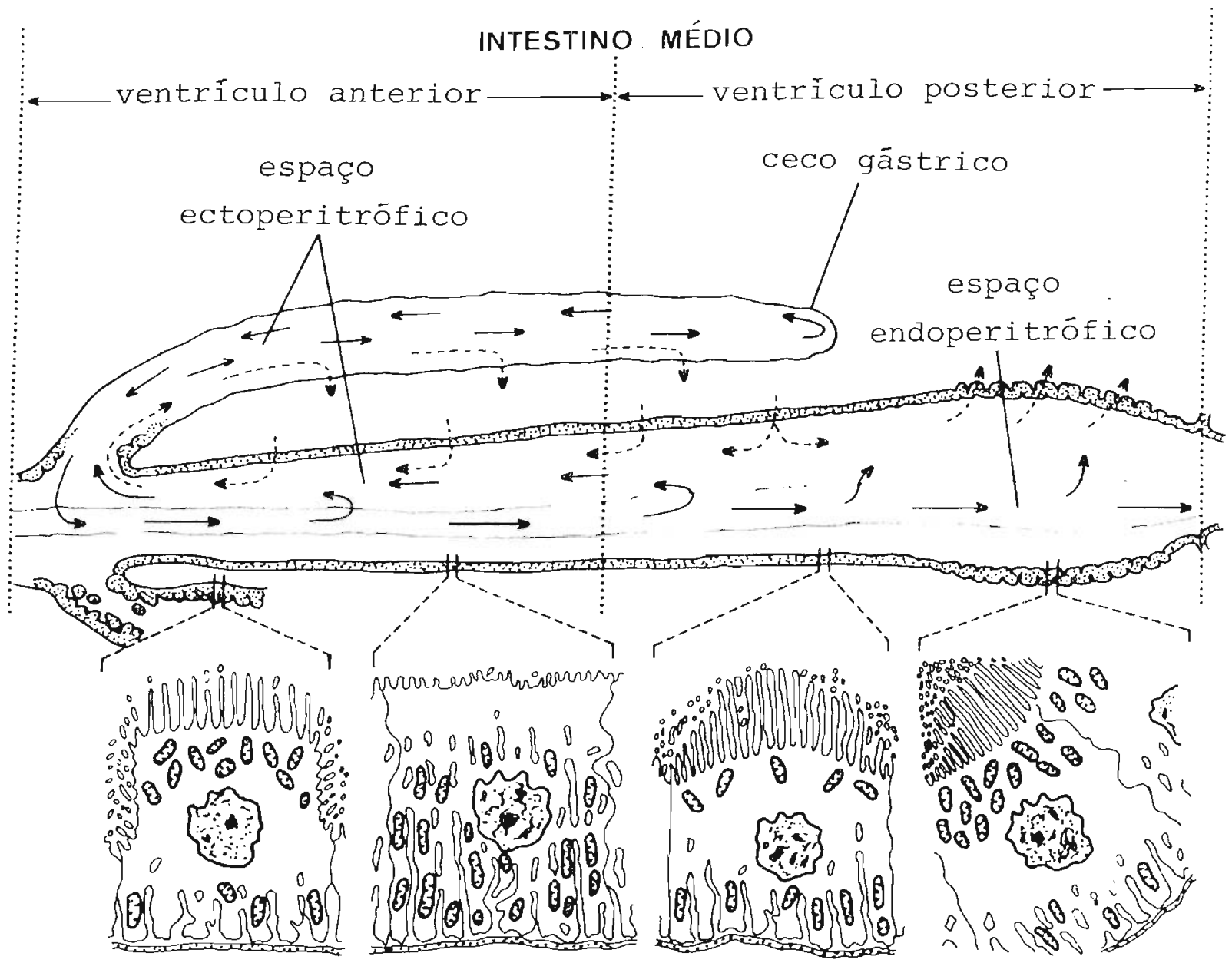

Figura 19 - Representação diagramätica dos fluxos de āgua e da circulação endo- ectoperitrófica de enzimas digestivas no intestino mé dio. Fluido endógeno (setas interrompidas) é transportado para o lū men na região do ventrículo anterior, e do ventrículo posterior pro ximal, por células caracterizadas por invaginações da membrana basal muito desenvolvidas e microvilosidades apicais pequenas. o flui do move-se principalmente em direção aos cecos e em menor extensão para a região com dobramentos do ventrículo posterior. Nesses sitios, o fluído é absorvido por células que apresentam longas microvilosidades apicais e invaginações da membrana basal moderadamente desenvolvidas. As enzimas digestivas (setas sólidas) penetram no espaço endoperitrófico na região anterior e são recuperadas para o espaço ectoperitrófico gradativamente à medida que as molëculas dos polimeros tornam-se suficientemente pequenas para acompanhar as enzimas através da membrana peritrófica. As enzimas e os nutrientes são então levados para os cecos e em menores quantidades para a região com dobramentos no ventrículo posterior, sitios onde ocorre a digestão terminal e. absorção do alimento. 
terior proximal apresentam atividades especificas de hidrolases da mesma ordem de magnitude daquelas observadas nas microvilosidades do ventrículo anterior (Tabela VIII) • Esses dados, estão de acordo com a observação (Item 3.4 e 3.5) de que a região proximal do ventrículo posterior e o ventrículo anterior possuem células semelhantes.

e) A maior parte da atividade de hidrolases de oligô meros são encontradas nas microvilosidades dos cecos e, con sequentemente, a maior parte da digestão terminal deve ocor rer nessas células. A maltase e as peptidases solúveis (res ponsáveis por cerca de $40 \%$ da atividade celular total) pro vavelmente não estão envolvidas na digestão terminal. A maltase solúvel é lisossômica e, provavelmente, está envolvida na digestão do glicogênio presente em corpos autofágicos formados durante a renovação dos contituintes celulares (cf. FERREIRA \& TERRA, 1980). As aminopeptidases celulares solúveis parecem ser hidrolases em via de serem secretadas para o lümen do tubo digestivo (ver ítem 4.1). O fato de que as carboxipeptidases encontram-se em quantidades consi deráveis no fluido ectoperitrófico (cf. TERRA et al.,1979), favorece a hipótese que as carboxipeptidases intracelulares solūveis sejam enzimas em via de serem secretadas, como dis cutido acima em relação às aminopeptidases.

f) Uma vez que é muito pouco provável que digestão ao nivel de membrana ocorra na superfície de uma célula envolvida em secreção de água (o substrato seria continuamente arrastado para longe da enzima), pode-se supor que os cecos gästricos e o ventrículo posterior estejam envolvidos em absorção. Por outro lado, o ventriculo anterior ( que praticamente não possui enzimas digestivas) secretaria água. Nesse sentido, é interessante notar que os dados ultraestru 
turais mostram que as células dos cecos gástricos e do ventrículo posterior são semelhantes entre si e que ambas diferem das células do ventrículo anterior. Além disso, uma inspeção nas invaginações da membrana basal dessas cê lulas levaram a sugestão de que as células do ventrículo anterior seriam secretoras, enquanto as células dos cecos gāstricos e do ventrículo posterior seriam absortivas . Desde que a capacidade dos cecos gástricos para transpor tar fluido do lúmen para a hemolinfa é muito maior que a região com dobramentos do ventrículo (a superficie trans portadora nos cecos gástricos é muito maior do que no ven trículo posterior), o principal fluxo de fluido no espaço ectoperitrófico deve ocorrer do ventrículo para os cecos. Contudo, deve haver também um fluxo menor de fluido da região proximal do ventrículc posterior para a região com dobramentos do ventrículo posterior. O fluxo principal de fluido ectoperitrófico (do ventrículo para os cecos) é - responsável pela circulação endo-ectoperitrófica das enzimas digestivas, que responde pelas baixas velocidades de excreção de enzimas (TERRA \& FERREIRA, 1981). Entretan to, as enzimas que permanecerem no espaço endoperitrófico da região posterior do ventrículo são provavelmente excre tadas, uma vez gue elas não podem sex alcançadas pelo flu xo principal de fluido.

g) Apesar das atividades das hidrolases de oligômeros serem maiores nas células dos cecos do que em qualquer outra região do intestino médio lo que é uma conse quência do número de microvilosidades ser maior nos cecos do que no ventrículo posterior), as microvilosidades puri ficadas das células dos cecos são mais ricas em peptida ses e mais pobres em oligossacaridases do que as microvi- 
losidades purificadas das células do ventrículo posterior. Esses dados estão de acordo com a observação de que a cir culação endo- ectoperitrófica é mais eficiente para a trip cina do que para a amilase e a celulase (CE. TERRA \& FERREIRA, 1981). Essa maior eficiência na circulação endoectoperitrófica da tripsina deve ser, provavelmente, conse quência de uma digestão mais rāpida das proteínas, que lo go produz oligopeptideos capazes de sair da membrana peri trófica, em contraste com uma digestão mais lenta de carboidratos, que produziria oligossacarídeos passiveis de atravessar a membrana periférica somente na região mais posterior do ventrículo (cf. TERRA \& FERREIRA, 1981; dis-cussão acima).

4.5. A função dos cecos do intestino médio e de estruturas seme lhantes nos insetos

Os cecos gástricos são evaginações do ventrículo que podem variar em nümero e posição ao longo do intestino médio nos di ferentes insetos. Principalmente entre as ordens ortopteróides (Fig. 20), e em larvas de Diptera, há evidências de que os cecos (que nesses insetos localizam-se perto do esôfago, Fig. 21) desem penham um papel importante na digestão e absorção (revisão em WIG GLESWORTH, 1972; TERRA et al., 1979; FERREIRA \& TERRA, 1980, Introkução). Como esses insetos apresentam uma membrana peritröfica, os cecos só podem estar envolvidos na digestão intermediária e final, pois somente as moléculas polimëricas parcialmente digeridas vão poder passar através dessa membrana e alcançar os cecos (cf. TERRA et al., 1979). Em vista disso, uma importante questão deve ser colocada. Porque um örgão, envolvido em digestão terminal e absorção, estaria localizado na região anterior do intestino médio e não na sua porção terminal, que seria uma a posição mais 
PTERYGOTA

Neoptera
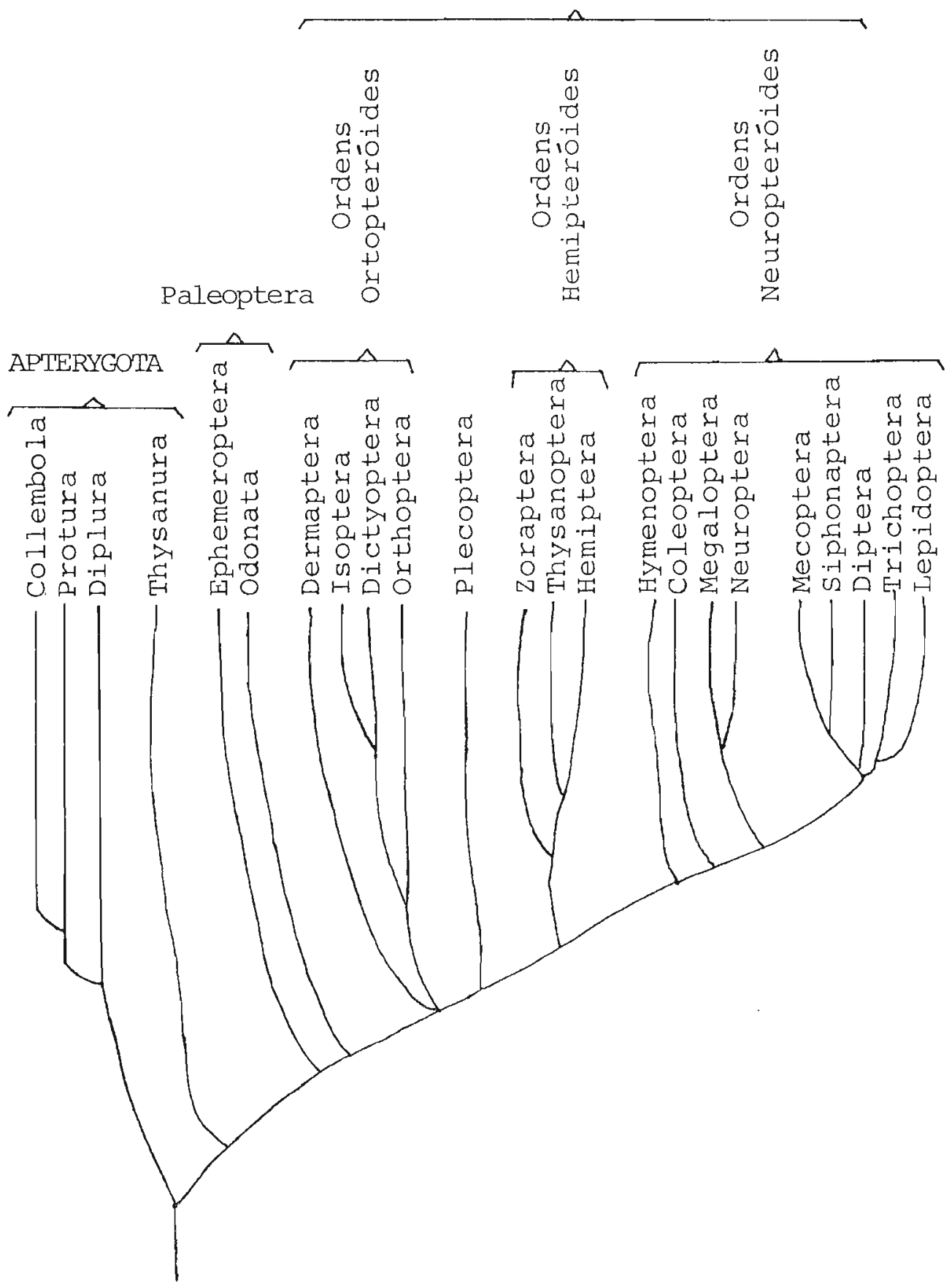

Figura 20 - Arvore filogenética de algumas ordens de insetos. Segundo ROSS (1965). 
A

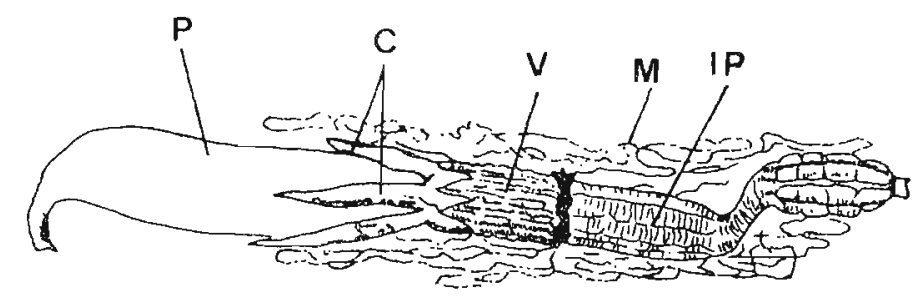

B
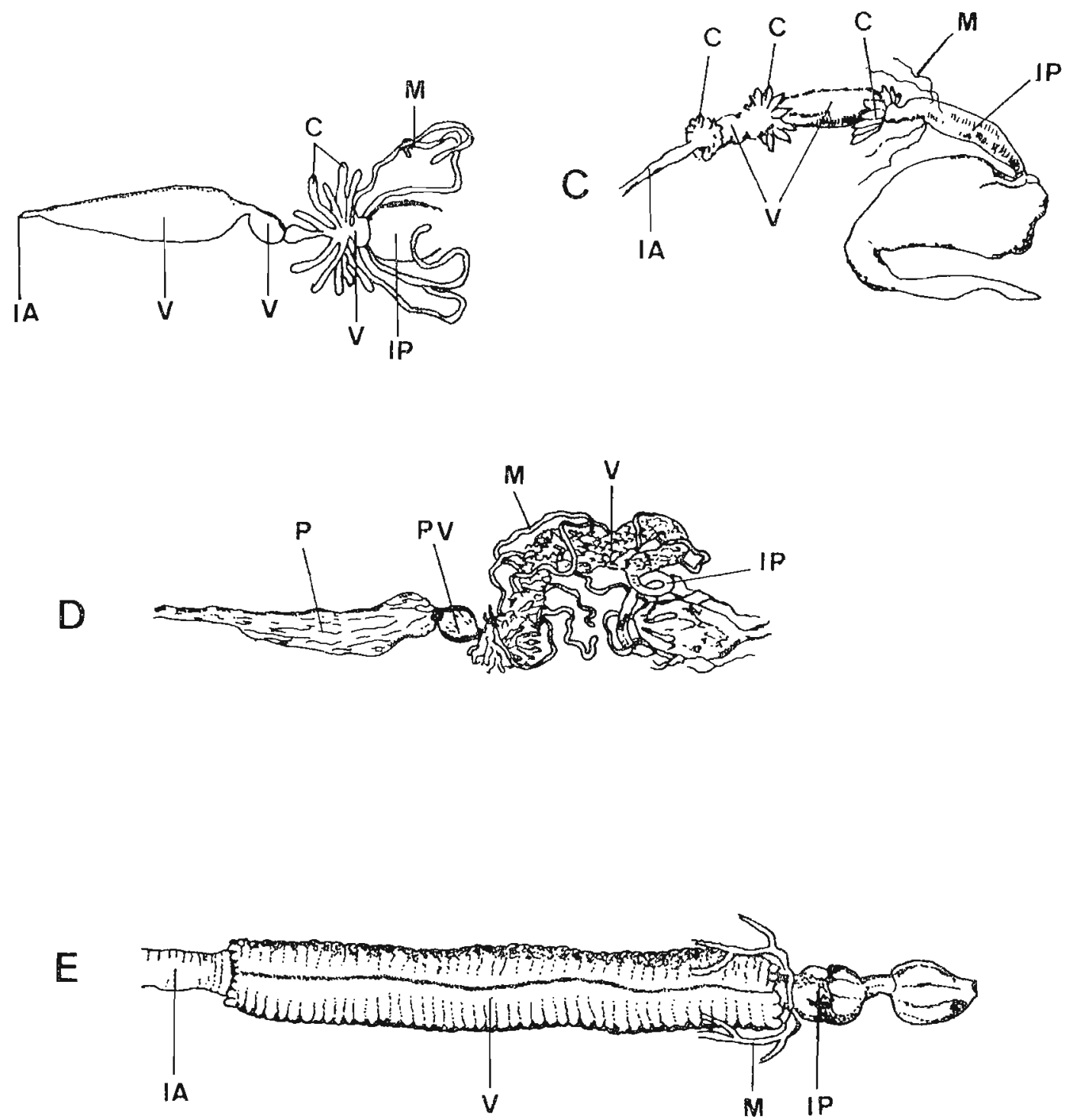

Figura 21 - Tipos anatômicos principais do tubo digestivo dos inse tos. A, Orthoptera: Acrididae (ninfa e adulto) redesenhado de SNOD GRASS (1935); B, Hemiptera: Heteroptera (ninfa e adulto) redesenha do de RICHARDS \& DAVIES (1977); C, Coleoptera: Scarabaeidae ( larva ) redesenhado de SNODGRASS (1935), D, Coleoptera: Carabidae (lar va) redesenhado de RICHARDS \& DAVIES (1977); E, Lepidoptera: Sphin gidae (larva) redesenhado de RICHARDS \& DAVIES (1977). 
"logica"? Uma explicação poderia ser a de que os cecos teriam se originado como evaginações do intestino médio anterior envolvidos em absorção de água. Essas células, agindo coordenadamente com as do ventrículo posterior, poderiam gerar um fluxo de fluido do ventrículo posterior para os cecos, permitindo a existência de uma circulação endo- ectoperitrófica de enzimas. Essa circulação parece ser responsável pela baixa taxa de excreção de enzimas digestivas em R.americana e também pelo transporte de alimento par cialmente digerido para os cecos (ver acima). A digestão interme diäria ocorre no lúmen dos cecos e a digestão terminal na superfí cie das microvilosidades de suas células (TERRA et al., 1979; TER RA \& FERREIRA, 1981; FERREIRA \& TERRA, 1980, ver também acima).

Nesse sentido, é interessante notar que insetos mais pri mitivos que R.americana, como os Orthoptera (Fig. 20), tem digestão terminal e absorção nos cecos (cf. WIGGLESWORTH, 1972), sem possuir enzimas ligadas à membrana plasmática e que estejam envol vidas na digestão terminal (cf. DROSTE \& ZEBE, 1974). Alēm disso, cinco meses após termos proposto a existência em $R$. americana de uma circulação de enzimas e fluidos no intestino médio, na sua primeira versão (TERRA \& FERREIRA, 1981), uma circulação de fluidos similar foi proposta em um orthoptera (DOW, 1981).

Os cecos dispostos em três séries anulares ao longo do ventriculo (p.e. larva de Scarabaeidae, Fig. 21) devem ter funções similares aqueles localizados prōximo ao esôfago. Outros tipos de cecos provavelmente não tem função digestiva. Assim, os cecos localizados na região posterior do ventrículo de espécies de Hemiptera Heteroptera (Fig. 21) sugadores de seiva (que perderam a câmara de filtração especializada que ocorre nos Homoptera) são ór gãos excretores de água não tendo importância na digestão(GOODCHILD; 1963). Os pequenos divertículos papiliformes, frequentemente tam bém chamados de cecos, que cobrem grande parte do ventrículo dos 
Coleoptera predadores (Fig. 21), são criptas de células regenerativas, e não cecos verdadeiros (SNODGRASS, 1935).

4.6. Aspectos físico-químicos da celobiase de R.americana

As dissacaridases intestinais de membrana melhor estuda das são as de mamíferos. Nesses organismos, essas enzimas possuem geralmente duas subunidades de peso molecular entre 140.000 e 240.000 cada e um segmento ancorador hidrofóbico de baixo peso molecular (de 3.500 a 4.500) continuo a uma ou às duas subunida des (ver KENNY \& MAROUX, 1982 e Introdução).

Até o presente não existem dados sobre dissacaridases li gadas a membranas plasmáticas de células intestinais de insetos, além dos apresentados nesse trabalho.

A papaina reduz o peso molecular aparente da celobiase dos cecos gástricos de R.americana de 106.000 para 65.000 , sem mudar os parâmetros catalíticos da enzima ou sua estabilidade em relação ao pH e temperatura. Esses dados sugerem que a papaina se para uma região catalítica e hidrofilica da celobiase de uma região catalítica e presumivelmente hidrofóbica, responsável pela inserção da enzima na membrana plasmätica das microvilosidades. o peso molecular do presumido segmento ancorador hidrofóbico, junta mente com o detergente a ele associado, seria de 41.000 . Este peso molecular é semelhante ao que tem sido encontrado em estudos análogos realizados com enzimas de mamíferos, nos quais foi demonstrado que a maior parte desse peso é devido ao detergente, o peptídeo ancorador contribuindo com apenas 3.500 a 4.500 unidades de peso molecular (cf. KENNY \& MAROUX, 1982). E possível que o mesmo ocorra com a celobiase de R. amexicana. 
4.7. Especificidade, inibição e mecanismo da celobiase de $R$.ameri cana

A celobiase purificada em gradientes de densidade, após solubilização por ação de papaina, hidrolisa B-glicosídeos, B-galactosídeos e $\beta$-fucosídeos e não hidrolisa $\alpha$-glicosídeos e $\alpha$-galacto sídeios. Experimentos de conpetição entre substratos mostraram que os $\beta-g 1 i-$ cosideos, $\beta$-galactosídeos e $\beta$--fucosideos são hidrolisados em um mesmo sítio ativo. Isso apöia a afirmação de que a celobiase pos sui uma especificidade ampla e que os diferentes glicosídeos não estão sendo hidrolisados por enzimas diferentes, contaminantes, pre sentes na preparação de celobiase.

Os valores de $K_{i}$ do pNPBGli $(0,4 \mathrm{mM})$, em uma reação onde celobiose é o substrato, e o $K_{i}$ de celobiose $(0,73 \mathrm{mM})$, em uma reação onde pNPBGli é o substrato, concordam com os valores de seus respectivos $\mathrm{Kms}(0,53 \mathrm{e} 0,61 \mathrm{mM})$. Como os $\mathrm{K}_{i} \mathrm{~s}$ de inibidores compe titivos lineares simples são as constantes de dissociação verda deiras dos complexos enzima-inibidores (cf. SEGEI, 1975), o fato deles concordarem com os respectivos kms sugere fortemente que es ses Kms são na realidade $\mathrm{K}_{\mathrm{S}} \mathrm{s}$, isto é, constantes de dissociação dos complexos enzima-substrato. Em outras palavras, a celobiase deve operar segundo uma cinética de equilíbrio rápido, e não de estado estacionário, como já foi sugerido acima a partir da constância observada do $\mathrm{Km}$ em relação ao $\mathrm{pH}$.

A inibição da celobiase por Tris foi estudada porque Tris é conhecido como bom inibidor competitivo de dissacaridases desde muito tempo (LARNER \& GILLESPIE, 1956; WALLENEELS \& FISCHER, 1960). Os valores do $\mathrm{K}_{i}$ de Tris para as dissacaridases intestinais de mamiferos são de regra inferiores a lmM (cf. SEMENZA \& von BALTHA ZAR, 1974). Entretanto, no caso da celobiase intestinal de $R$. ame ricana, Tris é um mau inibidor $\left(\mathrm{K}_{i}=40 \mathrm{mM}\right)$. 
O fato da hidrōlise da ligação glicosídica catalisada pela celobiase ocorrer sem inversão de configuração elimina os me canismos do tipo substituição nucleofilica bimolecular $\left(\mathrm{S}_{\mathrm{N}} 2\right)$, dei xando as possibilidades (LEGLER, 1975): (1) um mecanismo com um ion carbonium intermediārio capaz de ser atacado pela água por um lado só (isto é, um ataque Erontal) ou por ambos lados; (2) qualquer mecanismo que envolva um nümero par de substituições no $\mathrm{C}_{1}$ do glicosídeo, formando um intermediário enzima-substrato covalen te (Fig. 22).

O mecanismo 2 (Fig. 22) leva à previsão de que os substituintes no aglicone não devem influenciar a constante catalitica da reação, pois de regra o passo limitante de uma reação que envolve um intermediário covalente é a etapa de sua saída da enzi ma (cf. FERSHT, 1977). Uma inspeção na Tabela IX mostra claraman te que os substituintes no aglicone influenciam a constante cataIítica da reação da celobiase, sugerindo que o passo limitante da reação é a saída do aglicone. por outro lado, as evidências jā mencionadas que indicam que o complexo enzima-substrato está em equilíbrio com a enzima e substrato livres apoiam a hipótese de que - passo limitante da reação é a saída do aglicone.

o mecanismo 1 (Fig. 22) concorda com os dados experimen tais que indicam que o passo limitante da reação é a saída do aglicone, alëm de explicar a excepcional inibição da celobiase por ઈ-gliconolactona, como será discutido com detalhes a seguir.

Nos termos da teoria do estado de transição, a catálise enzimática é consequência do fato de que a enzima liga o estado de transição da reação não enzimätica correspondente mais fortemente do que o próprio substrato (WOLEENDEN, 1972; LIENHARD, 1973). A $\underline{s}$ sim, anālogos do estado de transição, isto é, compostos cujos com plexos estáveis com a enzima assemelham-se em estrutura ao estado de transição formado durante a reação, devem ser excelentes inibị 


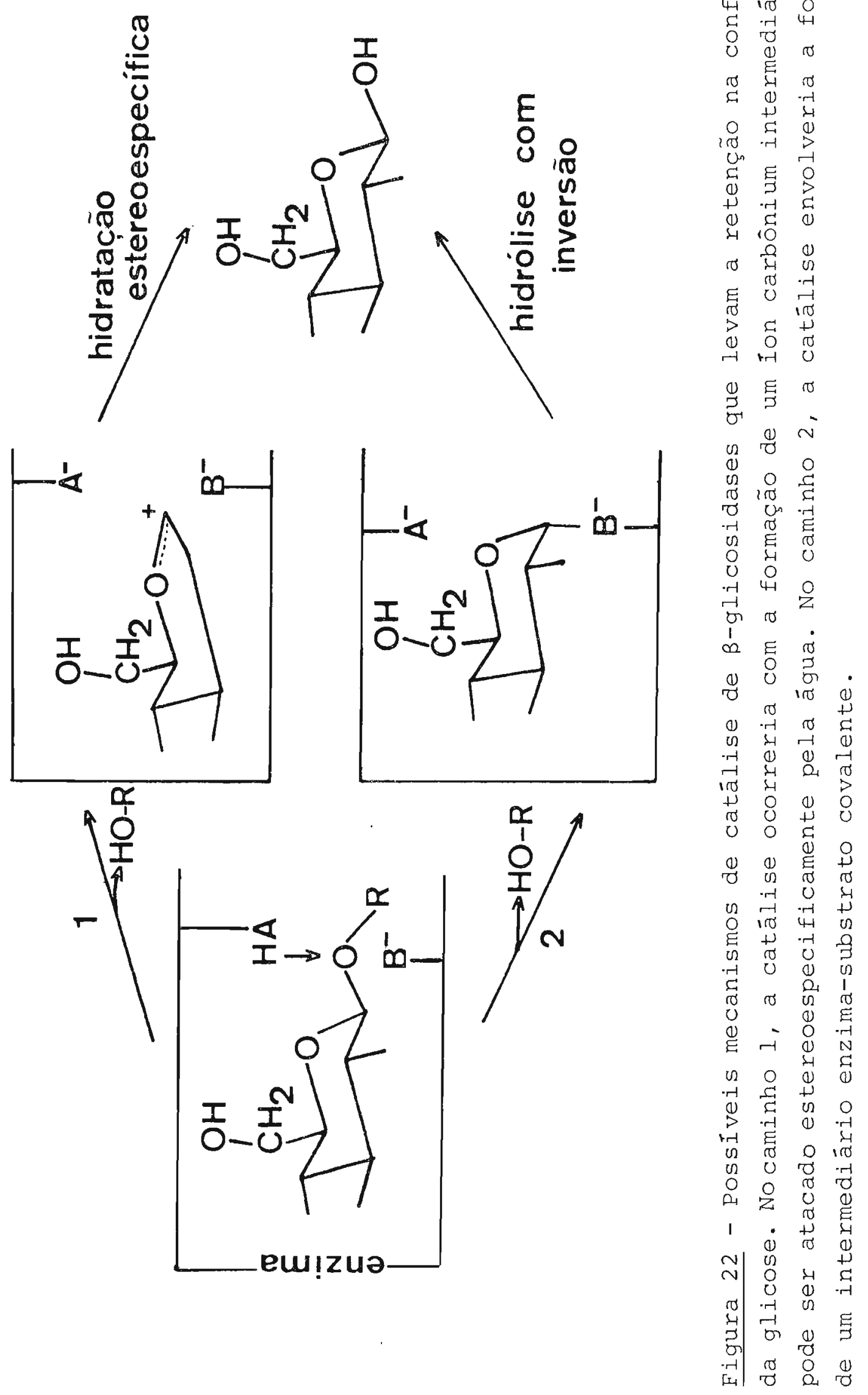


dores da catálise enzimátíca (WOLFENDEN, 1972; LIENHARD, 1973). Dessa forma, o fato da o-gliconolactona (mas não ācido glicônico) ligar-se à celobiase, com uma afinidade várias ordens de grandeza maior do que qualquer de seus substratos, sugere que a lactona é um análogo do estado de transição formado durante a catálise. Co mo a $\delta$-gliconolactona apresenta uma conformação planar na região formada pelos átomo $C_{2}-C_{1}-O\left(C_{5}\right)$ (LEVVY \& SNAITH, 1972), e poris so assume uma conformação em meia cadeira (sofá), o mesmo seria es perado do estado de transição formado durante a reação da celobia se. De acordo com as previsões, o íon carbonium formado no caminho 2 (Fig. 22) apresenta uma conformação em meia cadeira similar à da o-gliconolactona (cf. LEVVY \& SNAITH, 1972).

O fato de que lactonas correspondentes aos substratos de enzimas, para as quais existem fortes evidências da ocorrência de um estado de transição tipo carbonium, sejam fortes inibidores des sas enzimas, reforça a argumentação acima (p.ex., lisozima, SECEMSKI et aI., 1972).

A galactonolactona possui um $\mathrm{K}_{\mathrm{i}}$ cerca de 10 vezes menor que o $\mathrm{km}$ dos B-galactosídeos, o que sugere que os B-galactosideos são hidrolisados pela celobiase de R.americana por um mecanismo si milar ao discutido acima para os B-glicosídeos, além de estar de acordo com a discussão precedente que propõe que os B-galactosídeos são hidrolisados pelo mesmo sitio da celobiase que hidrolisa os $\beta$-glicosídeos. 


\section{RESUMO}

Os cecos gästricos de Rhynchosciara americana e de outros insetos são órgãos envolvidos em digestão terminal e/ou absorção de nutrientes. Devido a isso, a sua disposição na região anterior do ventrículo é intrigante. Uma explicação para essa localização seria a existência de uma circulação endo-ectoperitrō fica de fluidos e de enzimas digestivas, como foi proposto anteri ormente em R. amexicana. Afim de procurar reforçar o modelo proposto procurou-se obter dados sobre a ultraestrutura das cëlulas do tubo digestivo e sobre a composição enzimática de suas mícrovị losidades.

As células dos cecos edo ventrículo posterior distal tem uma ultraestrutura bastante semelhante; elas possuem grandes microvilosidades apicais e a membrana plasmática basal apresenta in vaginações com mitocôndrias associadas, embora a maioria dessas organelas sejam encontradas no citoplasma apical. O compartimento extracelular delimitado por essas invaginações da membrana basal apresenta poucas aberturas para a hemolinfa, o que dá à cêlula a possibilidade de concentrar solutos nesse compartimento. As células do ventrículo anterior possuem microvilosidades apicais muito pequenas e um sistema elaborado de invaginações da membrana basal, com muitas mitocôndrias associadas, e que se estendem atë quase o ápice das cēlulas. O compartimento extracelular delimitą do por essas invaginações apresenta, nessas células, grande número de aberturas para a hemolinfa. O ventrículo posterior proxi mal representa uma região de transição entre o ventrículo ante rior e o ventrículo posterior distal. A ultraestrutura dos cecos e ventrículo posterior distal é coerente com uma função na absorção de fluidos, enquanto que aquela do ventrículo anterior é coerente com uma função de secreção de fluidos. 
A análise da composição de enzimas nas microvilosidades das diferentes regiões do intestino médio mostrou novamente que as células dos cecos e do ventrículo posterior distal são semelhantes e também que devem estar envolvidas na digestão terminal dos nutrientes, pois possuem alta atividade específica para hidro lases de oligômeros. As células do ventrículo anteriox (e do ven trículo posterior proximal) possuem microvilosidades com atividade específica muito baixa para as hidrolases de oligômeros, como seria de esperar para uma cëlula que estivesse secretando fluidos, pois o substrato seria continuamente arrastado para longe da enzi ma. Os dados obtidos permitiram reforçar e refinar o modelo da circulação endo- ectoperitrófica de enzimas em R. americana.

Para melhor compreensão da digestão terminal de proteínas em $R$. americana, aminopeptidases de diferentes regiões do tubo digestivo foram estudadas. As aminopeptidases do lúmen e do citossol das células dos cecos são semelhantes, e ambas diferem daquelas presentes na membrana plasmática dessas células. Os dados obtidos apoiam a hipótese de que a maioria das aminopeptidases so Iúveis nas células dos cecos são enzimas em via de serem secretadas para o Iúmen e somente uma quantidade muito pequena pode ter uma função intracelular.

Para iniciar o estudo das propriedades das enzimas envolvidas na digestão terminal, a celobiase ligada a membrana plas mātica dos cecos foi escolhida.

A celobiase solubilizada porTriton X-100 apresenta um pe so molecular de 106.000 e um pI de 5,4, enquanto que a solubiliza ção por papaína resulta em uma molécula com peso molecular de 65.000 e um pI de 4,7. A celobiase solubilizada por papaína e pu rificada por centrifugação em gradientes de densidade hidrolisa B-glicosídeos, $\beta$-galactosídeos e $\beta$-fucosideos em um mesmo sítio ativo. Com base na comparação entre os kis e os kms para celobio 
se e para pNPBGli e na constância do Km obtido em diferentes pHs, tem-se uma forte evidência que essa enzima opera segundo uma cinê tica de equilíbrio rápido e não de estado estacionário. o fato da hidrólise da ligação B-glicosídica ocorrer sem inversão da configuração, ocorrer uma grande inibição da celobiase pela $\delta$-gli conolactona e substituintes do radical aglicone influenciarem a constante catalítica sugere que, no mecanismo de catálise da celobiase, hã formação de um ion carbōnium intermediārio e que não hã formação de um complexo covalente enzima-substrato. 


\section{ABSTRACT}

The gastric caeca of Rhynchosciara americana and other insects are involved in terminal digestion and/ox absorption of nutrients. Due to that, their occurrence near the oesophagus is puzzling. One explanation for this should be the existence of an endo- ectoperitrophic circulation of fluids and digestive enzymes as previously proposed for $R$. americana.

In order to support the proposed model of endoectoperitrophic circulation of digestive enzymes, fine structural and enzymological data on the midgut cells were obtained.

Midgut caecal and distal posterior ventricular cells have a similar ultrastructure characterized by large apical microvilli and a basal plasma membrane infolded with associated mitochondria which are, nevertheless, more conspicuous in the apical cytoplasm. The fact that the basal plasma membrane infoldings constitute an extracellular compartment, with few openings into the underlying extracellular space, should permit the cell concentrate solutes in that compartment. The anterior ventricular cells possess small microvilli disposed in the cell apexes and elaborate mitochondria-associated basal plasma membrane infoldings extending almost to the tips of the cells. These infoldings display regular openings into the underlying extracellular space. The proximal posterior ventriculus represents a transition region between the anterior ventriculus and the distal posterior ventriculus. The fine structure of caeca and distal posterior ventricular cells is in accordance to their presumed function in fluid absorption, whereas the fine structure of anterior ventricular cells suggests a function in fluid secretion. Hydrolase assays in microvilli samples prepared from cells of different midgut regions showed that caeca and distal 
posterior ventricular cells are alike in displaying high specific activities for digestive enzymes, suggesting a role in terminal digestion. In contrast, very low specific activities of digestive enzymes were found in anterior ventricular cells, in accordance to their proposed function in fluid secretion. The results lend support to the model of the endo- ectoperitrophic circulation of digestive enzymes in $R$. americana.

In order to extend our knowledge on protein terminal digestion, the aminopeptidases from cytosol and 1 umen were found to be similar and to differ from caecal microvillar aminopeptidades. The data support the assumption that the majority of the soluble aminopeptidases from the caecal cells are enzymes en route to their being secreted and only a minor amount would have a typical intracellular function.

Caecal plasma membrane-bound cellobiase was chosen to initiate a detailed study of the properties of the enzymes involved in terminal digestion.

The Triton X-100-solubilized cellobiase displays a molecular weight of 106.00 and a pI of 5.4, whereas the papaintreated cellobiase shows a molecular weight of 65.000 and a pI of 4.7. The papain-solubilized cellobiase, after being purified by density gradient centrifugation, hydrolyze B-glucosides, $\beta$-galactosides and $\beta$-fucosides in the same active site. The cellobiase seems to operate according to a rapid equilibrium kinetics, since the $\mathrm{Km}$ for cellobiose is constant over a wide range of pHs and the $\mathrm{Km}$ for cellobiose and pNPBGlu are identical to their $K_{i} s$ in a experiment of competition between substrates. The hydrolysis of the $\beta$-glucosidic bound occurs without inversion

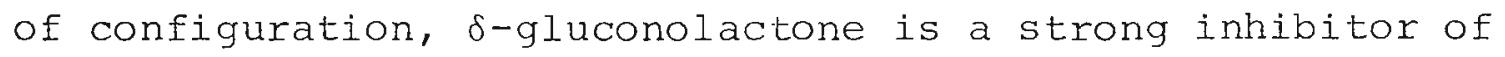
cellobiase and substituints in the substrate aglycone affects the catalytic constant of the reaction. These data support the 
assumption that the mechanism of the reaction catalysed by cellobiase involves the intermediary formation of a carbonium ion, instead of a glucosyl-enzyme intermediate. 


\section{REFERENCIAS BIBLIOGRĀFICAS}

Barnard, E.A. (1973). Comparative biochemistry of digestive enzymes. In Comparative Animal Physiology (Ed. By Prosser C.I.) pp. 139-146. Saunders, Philadelphia.

Baker, J.E. (1981). Isolation and properties of digestive carboxypeptidases from midguts of larvae of the black carpet beetle Attagenus megatoma. Insect Biochem l1, $583-592$.

Baker, J.E. \& Woo, S.M. (1981). Properties and specificities of a digestive aminopeptidase from larvae of Attagenus megatoma (Coleoptera: Dermestidae). Comp. Biochem. Physiol. 69B, 189-194.

Benajiba, A. \& Maroux, S. (1980). Purification and characterization of an aminopeptidase A from hog intestinal brush-border membrane. Eur. J. Biochem. 107, 381-388.

Berridge, M. (1980). A structural analysis of intestinal absorption. In Insect Ultrastructure (Eds. by Neville, A.C.). Symp. R. Ent. Soc. London. 5, 135-151.

Boya, N.D. \& Martin, M.M. (1975). Faecal proteinases of the fungusgrowing ant, Atta texana: their fungal origin and ecological significance. J. Insect Physiol. 21, 1815-1820.

Brunner, J.; Hauser, H.; Braun, H.; Wilson, K.J.; Wacker, H. ; O'Neill, B. \& Semenza, G. (1979). A mode of association of the enzyme complex sucrase-isomaltase with the intestinal brush border membrane. J. biol. chem. 254, $1821-1828$.

Buonocore, V.; Poerio, E.; Silano, V. \& Tomasi, M. (1976). Physical and catalytical properties of $\alpha$-amylase from Tenebrio molitor. L. Larvae. Biochem. J. 153, 621-625. 
Chippendale, G.M. (1978). The function of carbohydrates in insect life process. In Biochemistry of Insects. (Ed. by Rockstein, M.) pp. 1-55, Academic Press, New York.

Coiro, J.R.R.; Weige, D.R.; Kisielius, J.; Menezes, H. \& Bilotta, J. A.T. (1972). A new embedding medium (Polylite 8001 ) for biological material. Cienc. Cult. 24, 660-662.

Crane, R.K. (1968). A concept of the digestive absortive surface of the small intestine. In Handbook of Physiology. (Ed. by Code, C.F.) Vol. 5, Alimentary Canal section 6, pp. 2535-2542, Amer. Physiol. Soc. Washington.

Dadd, R.H. (1970). Digestion in insects. In Chemical Zoology. (Ed. by Florkin, M. \& Scheer, B.T.) Vol. 5, Arthropoda Part A, pp. 117-145, Academic Press, New York.

Dahlman, D.I. (1971). Purification and properties of trehalase from tobacco hormworm larval. J. Insect Physiol. 17, $1677-1687$.

Dahlquist, A. (1968). Assay of intestinal disaccharidases. Anal. Biochem. 22, 99-107.

Derr, R.F. \& Randa11, D.D. (1966). Trehalase of the differential grasshopper, Melanoplus differentialis. J. Insect Physiol. $12,1105-1114$.

Desnuelle, P. (1979). The tenth Sir Hans Krebs lecture. Intestine and renal aminopeptidase: a model of a transmembrane protein. Eur. J. Biochem. 101, 1-11.

Doumeng, C. \& Maroux, S. (1979). Aminotripeptidase a cytosol enzyme from rabbit intestinal mucosa. Biochem. J. 177, 801-808.

Dow, J.A. (1981). Countercurrent flows, water movements and nutrient absorption in the locust midgut. J. Insect Physiol. $27,579-585$. 
Droste, H.J. \& Zebe, E. (1974). Carbohydrasen und Kohlenhydratverdauung in Darmtrakt von Locusta migratoria J. Insect, Physiol. 20, 1639-1657.

De Duve, C.; Pressman, B.C.; Gianetto, R.; Wattiaux, R. \& Appelmans, F. (1955). Tissue fractionation studies. 6 . Intracellular distribution patterns of enzymes in rat liver tissue. Biochem. J. $60,604-617$.

Erlanger, B.F.; Kokowsky, N. \& Cohen, W. (1961). The preparation and properties of two new chromogenic substrates of trypsin. Arch. Biochem. Biophys. 95, 271-278.

Evans, W.H. (1978). Preparation and characterization of mammalian plasma membranes. In Laboratory techniques in biochemistry and molecular biology. (Ed. by Work, T.S. \& Work, E.) Vol. 7, Part 1.North-Holland, Amsterdam.

Evans, W.A.L. \& Payne, D.W. (1964). Carbohydrases of the alimentary tract of the desert locust, Schistocerca gregaria. Forsk. J. Insect Physiol. 10, 657-674.

Ferracci, H. \& Maroux, S. (1980). Rabbit intestinal aminopeptidase $\mathrm{N}$ : Purification and molecular properties. Biochim. Biophys. Acta. 599, 448-463.

Ferreira, C. (1979). Digestão terminal em Rhynchosciara americana. Dissertação de Mestrado, Universidade de são Paulo. Ferreira, C. \& Terra, W.R. (1980). Intracellular distribution of hydrolases in midgut caeca from an insect with emphasis on plasma membrane-bound enzymes. Comp. Biochem. Physiol. $\underline{66 \mathrm{~B}}, 467-473$.

Fersht, A. (1977). Enzyme structure and mechanism. Freeman, San Francisco. 
Fink, D.E. (1932). The digestive enzymes of the colorado potato beetle and the influence of arsenicals on their activity. J. Agric. Res. 45, 471-482.

Freeman, M.A. (1967). Proteolytic enzymes of the crop fluid from Locusta migratoria. L. Comp. Biochem. Physiol. 20, 10131015 .

Friedman, S. (1980). The purification and properties of trehalase isolated from Phormia regina, Meig. Arch. Biochem. Biophys. $87,252-258$.

Garcia, E.S.; Guimarães, J.A. \& Prado, J.L. (1978). Purification and characterization of a sulfhydryl-dependent protease from Rhodnius prolixus midgut. Archs. Biochem. Biophys. $188,315-322$.

Giebel, P.E. \& Domnas, A.J. (1976). Soluble trehalases from larvae of the mosquito, Culex pipiens, and the fungal parasite, Lagenidium giganteum. Insect Biochem。 $\underline{6}$, 303-311.

Goodchild, A.J.P. (1963). Studies on the functional anatomy of the intestines of Heteroptera. Proc. Zool. Soc. Lond. 141, $851-910$.

Gooding, R.H. \& Rolseth, B.M. (1976). Digestive processes of haematophagous insects. XI. Partial purification and some properties of six proteolytic enzymes from the tsetse fly Glossina morsitans morsitans Westwood (Diptera: Glossinidae). Can J. Zool, 54, 1950-1959.

Gorvel, J.P.; Benajiba, A. \& Maroux, S. (1980). Purification and characterization of the rabbit intestinal brush-border aminopeptidase A. Biochim. Biophys. Acta. 615, 271-274.

Guilloux, E.; Cortois, J.E. \& Percheron, F. (1968). Etude d'une trēhalase purifieé extraite du hanneton (Melolontha vulgaris). Bull. Soc. Chim. Biol. 50, 1915-1931. 
Hedrick, J.I. \& Smith, A.J. (1968). Size and charge isomer separation and estimation of molecular weights of proteins by discgel electrophoresis. Archs. Biochem. Biophys. 126, 155164 .

Hestrin, S. (1949). The reaction of acetylcholine and other carboxylic acid derivatives with hydroxylamine and its analytical application. J. Biol. Chem. 180, 249-261.

Hopsu, U.K.; Mäkinen, K.K. \& Glenner, G.G. (1966). Purification of a mammalian peptidase selective for N-terminal arginine and lysine residues: aminopeptidase B. Archs. Biochem. Biophys. 114, 557-566.

House, H.L. (1974). Digestion. In The physiology of insecta. (Ed. by Rockstein, M.) $2^{\text {nd }}$ ed. V.5, pp. 63-117, Academic Press, New York.

Huber, R.E. (1975). The purification and study of a honey bee abdominal sucrase exhibiting unusual solubility and kinetic properties. Archs. Biochem. Biophys. 168, 198-209.

Huber, R.E. \& Lefebvre, Y.A. (1971). The purification and some proterties of soluble trehalase and sucrase from

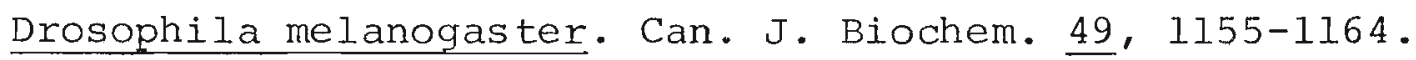

Huber, R.E. \& Mathison, R.D. (1976). Physical, Chemical, and enzymatic studies on the major sucrase of honey bees (Apis mellifera). Can. J. Biochem. 54, 153-164.

Huber, R.E. \& Thompson, D.J. (1973). Studies on a honey bee sucrase exhibiting unusual kinetics and transglucolytic activity. Biochemistry 12, $4011-4020$.

Jany, K.D.; Pfleiderer, G. \& Molitoris, H.P. (1974). Purification and some physical properties of a chymotrypsin-like protease of the larvae of the hornet, Vespa orientalis. Eur. J. Biochem. 42, 419-428. 
Kalf, G.F. \& Rieder, S.V. (1958). The purification and properties of trehalase. J. biol. chem. 230, 69I-698.

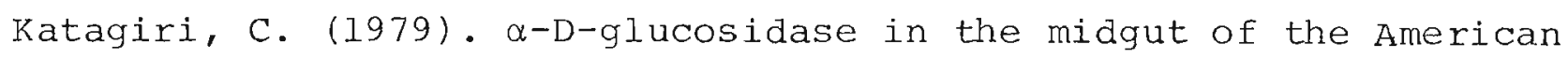
cockroach, Periplaneta americana. Insect Biochem. 9 , 205-209.

Keilin, D. \& Hartree, E.F. (1972). Specificity of glucose oxidase (Notatin). Biochem. J. 50, 331-34l.

Kenny, A.J. \& Booth, A.G. (1978). Microvilli: their ultrastructure, enzymology and molecular organization. Essays Biochem. $14,1-44$.

Kenny, A.J. \& Maroux, S. (1982). Topology of microvillar membrane hydrolases of kidney and intestine. Physiol. Reviews. $62,91-128$

Khan, M.A. (1962). The distribution of dipeptidase activity in the digestive system of Locusta migratoria. L. and Dysdercus fasciatus. Comp. Biochem. Physiol. 6, 169-170.

Kim, Y.S. \& Brophy, E.J. (1976). Rat, intestinal brush border membrane peptidases. I. Solubilization, purification, and physicochemical properties of two different forms of the enzyme. J. Biol. Chem. 251, 3199-3205.

Kim, Y.S.; Kim, Y.W. \& Sleisenger, M.H. (1974). Studies on the properties of peptide hydrolases in the brush-border and soluble fractions of small intestinal mucosa of rat and man. Biochim. Biophys. Acta. 370, 283-296.

Lara, F.J.S.; Tamaki, H. \& Pavan, C. (1965). Laboratory culture of R. angelae. Am. Nat. 99, 189-191.

Larner,J. \& Gillespie, R.E. (1956). Gastrointestinal digestion of starch. II. Properties of the intestinal carbohydrases. J. Biol. Chem. 223, 709-726. 
Lasker, R. \& Giese, A.C. (1956). Cellulose digestion by the silverfish Ctenolepisma lineata. J. exp. Biol. 33, 542553.

Law, J.H.; Dunn, P.E. \& Kramer, K.J. (1977). Insect proteases and peptidases. Adv. Enzymol. 45, 389-425.

Legler, G. (1975). The mechamism of action of glycosidases. Acta Microbiol. Acad. Sci. hung. 22, 403-409.

Levvy, G.A. \& Snaith, S.M. (1972). The inhibition of glycosidases by aldonolactones. Adv. Enzymol. 36, 151-181.

Lienhard, G.E. (1973). Enzymatic catalysis and transition-state theory. Science 180, 149-154.

Lowry, O.H.; Rosebrough, J.J.; Farr. A.L. \& Randall R.J. (1951). Protein measurement with the fenol reagent. J. Biol. Chem. $193,265-275$.

Marques, M.D. (1976). Aspectos anatômicos e fisiológicos dos estágios imaturos de Rhynchosciara americana (Wiedemann, 1821). (Diptera, Sciaridae), Tese de Doutoramento, Universidade de são Paulo.

Maroux, S. \& Louvard, D. (1976). On the hydrophobic part of aminopeptidase and maltases which bind the enzyme to the intestinal brush border membrane. Biochim. Biophys. Acta. $\underline{419}, 189-195$.

Maroux, S.; Louvard, D. \& Baratti, J. (1973). The aminopeptidase from hog intestinal brush border. Biochim. Biophys. Acta. $321,282-295$.

Martin, M.M. \& Martin, J.S. (1978). Cellulose digestion in the midgut of the fungus-growing termite Macrotermes natalensis: the role of acquired digestive enzymes. Science. 199, $1453 \div 1455$ 
Martin, M.M. \& Martin, J.S. (1979). The distribution and origins of the cellulolytic enzymes of the higher termite, Macrotermes natalensis. Physiol. Zool. 52, 11-21.

Martin, R.G. \& Ames, B.N. (1961). A method for determining the sedimentation behavior of enzymes: application to protein mixtures. J. Biol. Chem. 236, 1372-1379.

Marzluf, G.A. (1969). Studies of trehalase and sucrase of Drosophila melanogaster. Archs. Biochem. Biophys. 134, 8-18.

Miller, J.W.; Kremer, K.J. \& Law, J.H. (1974). Isolation and partial characterization of the larval midgut trypsin from the tobacco hornworm, Manduca sexta, Johannson (Lepidoptera: Sphingidae). Comp. Biochem. Physiol. 488 , $117-129$.

Moosecker, M.S. (1976). Brush border motility. Microvillar contraction in Triton-treated brush borders isolated from intestinal epithelium. J. Cell. Biol. 71, 417-433.

Morgan, M.R.J.(1975a). Initial characterization of the gut cellobiase of the African migratory locust, Locusta migratoria migratorioides. Insect. Biochem. ㅁ, 251-264.

Morgan, M.R.J. (1975b). Initial characterization of the gut lactase of the African migratory locust, Locusta migratoria migratorioides. Insect. Biochem. $\underline{5}, 479-487$.

Morgan, M.R.J. (1975c) . Relationship between gut cellobiase, lactase, aryl $\beta$-glucosidase, and aryl $\beta$-galactosidase activities of Locusta migratoria. Insect Biochem. $\underline{5}$, 609-617.

Morgan, M.R.J. (1976). Gut carbohydrases in locusts and grasshoppers. Acrida $\underline{5}, 45-58$. 
Nicholson, J.A. \& Kim, Y.S. (1975). A one-step L-amino acid oxidase assay for intestinal peptide hydrolase activity . Analyt. Biochem. 63, 110-117.

Norēn, O.; Sjöström, H. \& Josefsson, L. (1973). Studies on a soluble dipeptidase from pig intestinal mucosa. I. Purification and specificity. Biochem. Biophys. Acta. $327,446-456$.

Podoler, H. \& Applebaum, S.W. (1971). The $\alpha$-amylase of the beetle Callosobruchus chinensis : Purification and properties. Biochem. J. 121, 317-320.

Reynolds, E.S. (1963). The use of lead citrate at high pH as an electron-opaque stain in electron microscopy. J. Cell. Biol. 17, 208-212.

Richards, A.G. \& Richards, P.A. (1977). The peritrophic membranes of insects. Ann. Rev. Entomol. 22, 219-240.

Richards, O.W. \& Davies, R.G. (1977). Imm's General textbook of entomology, $10^{\text {th }}$ edn. Chapman, London.

Rosen, H. (1957). A modified ninhydrin colorimetric analysis for amino acids. Archs. Biochem. Biophys. 67, 10-15.

Ross, H.H. (1965). A textbook of entomology, $3^{\text {th }}$ edn. John Wiley \& Sons, New York.

Sabatini, D.D.; Bensch, K. \& Barrnett, R.J. (1963). Cytochemistry and electron microscopy. The preservation of cellular ultrastructure and enzymatic activity by aldehyde fixation. J. Cell. Biol. 17, 19-58.

Saito, S. (1960). Trehalase of silkworm, Bombyx mori: purification and properties of the enzyme. J. Biochem. (Tokyo) 48 , $101-109$. 
Secemski, I.I.; Lehrer, S.S. \& Lienhard, G.E. (1972). A transition state analog for lysozyme. J. Biol. Chem. 247, 4740-4748.

Schmitz, J.; Preiser, H.; Maestracci, D.; Ghosh, B.K.; Cerda, J.J. \& Crane, R.K. (1973). Purification of the human intestinal brush border membrane. Biochim. Biophys. Acta. 323, $98-112$.

Schray, K.J. \& Benkovic, S.J. (1978). Anomerization rates and enzyme specificity for biologically important sugars and sugar phosphates. Accounts Chem. Res. 11, 136-141.

Segel, I.H. (1975). Enzyme kinetics: behavior and analysis of rapid equilibrium and steady-state enzyme systems. John Wiley \& Sons, New York.

Semenza, G. \& von Balthazar, A.K. (1974). Steady-state kinetics of rabbit-intestinal sucrase. Kinetic mechanism, $\mathrm{Na}^{+}$ activation, inhibition by Tris (hydroxymethyl) aminomethane at the glucose subsite. Eur. J. Biochem. 41, 149-162.

Semenza, G.; Curtis, H.C.; Raunhardt, O.; More, P. \& Müler, M. (1969). The configurations at the anomeric carbon of the reaction products of some digestive enzymes. Carbohyd. Res. $10,417-428$.

Sjöström, H.; Norén, O.; Christiansen, L.; Wacker, H. \& Semenza, G. (1980). A fully active, two-active-site, sigle-chain sucrase-isomaltase from pig small intestine. Implications for the biosynthesis of a mammalian integral stalked membrane protein. J. biol. Chem. 255, 11332-11338.

Sjöström, H.; Norēn, O. \& Josefssom L. (1973). Purification and specificity of pig intestinal prolidase. Biochim. Biophys. Acta. 327, 457-470. 
Skovbjerg, H.; Sjöström, H. \& Norén, O. (1981). Purification and characterization of amphiphilic lactase/phlorizin hydrolase fom human small intestine. Eur. J. Biochem. $114,653-661$.

Snodgrass, R.E. (1935). Principles of Insect Morphology. McGrawHill, New York.

Sterchi, E.E. \& Woodley, J.F. (1980). Peptide hydrolases of the human small intestinal mucosa: distribution of activities between brush border membranes and cytosol. Clin. Chim. Acta. $102,49-56$.

Terra, W.R. '\& De Bianchi, A.G. (1975). Rate of cocoon production by the larva of the fly Rhynchosciara americana and storage sites of precursors. J. Insect Physiol. 21, $1547-1550$.

Terra, W.R., De Bianchi, A.G.; Gambarini, A.G. \& Lara, F.J.S. (1973). Haemolymph amino acids and related compounds during cocoon production by the larvae of the fly Rhynchosciara americana. J. Insect Physiol. 19, 2097-2160.

Terra, W.R. \& Ferreira, C. (1981). The physiological role of the peritrophic membrane and trehalase: digestive enzymes in the midgut and excreta of starved larvae of Rhynchosciara J. Insect. Physiol. 27, 325-331.

Terra, W.R.; Ferreira, C. \& De Bianchi, A.G. (1975). Distribution of nutrient reserves during spinning in tissues of the larva of the fly, Rhynchosciara americana. J. Insect Physiol. 21, 1501-1509.

Terra, W.R.; Ferreira, C. \& De Bianchi, A.G. (1977). Action pattern, kinetical properties and electrophoretical studies of an alpha amylase present in midgut homogenates from Rhynchosciara americana (Diptera) larvae. Comp. 
Biochem. Physiol. 56B, 201-209.

Terra, W.R.; Ferreira, C. \& De Bianchi, A.G. (1978). Physical properties and Tris inhibition of an insect trehalase and a thermodynamic approach to the nature of its active site. Biochim. Biophys. Acta 524, 131-141.

Terra, W.R.; Ferreira, C. \& De Bianchi, A.G. (1979). Distribution of digestive enzymes among the endo- and ectoperitrophic spaces and midgut cells of Rhynchosciara and its physiological significance. J. Insect Physiol. 25 , $487-494$.

Terra, W.R.; Ferreira, C. \& De Bianchi, A.G. (1980). Carotenoids from midgut and from haemolymph proteins of Rhynchosciara (Diptera: Sciaridae) and their metabolic implications. Comp. Biochem. Physiol. 66B, 491-497.

Threadgold, L.T. (1976). The Ultrastructure of the Animal Cell. Pergamon, Oxford.

Tipton, K.F. \& Dixon, H.B.F. (1979). Effects of pH on enzymes. Meth. Enzymol. 63, 183-234.

Turunem, S. (1979). Digestion and absorption of lipids in insects. Comp. Biochem. Physiol. 63A, 455-460.

Ugolev, A.M. \& De Laey, P. (1973). Membrane digestion. A concept of enzymic hydrolysis on cell membranes. Biochim. Biophys. Acta. 300, 105-128.

Wacker, H.; Jaussi, R.; Sonderegger, P.; Dokow, M.; Ghersa, P.; Hauri, H.P.; Christen, P. \& Semenza, G. (1981). Cellfree synthesis of the one-chain precursor of a major intrinsic protein complex of the small-intestinal brush border membrane (pro-sucrase-isomaltase). Febs. Lett. $136,329-332$. 
Wallenfels, K. \& Fischer, J. (1960). Untersuchungen über milchzuckespaltende Enzyme. X. Die Lactase des Kälberdarms. Hoppe-Seyler's z. Physiol. Chem. 321, $223-245$.

Ward, C.W. (1975a). Resolution of proteases in the keratinolytic larvae of the webbing clothes moth. Aust. J. biol. Sci. $28,1-23$.

Ward, C.W. (1975b). Aminopeptidases in webbing clothes moth larvae. Properties and specificities of the enzymes of intermediate electrophoretic mobility. Biochim. Biophys. Acta. $410,361-369$.

Ward, C.W. (1975c). Aminopeptidases in webbing clothes moth larvae. Properties and specificities of the enzymes of highest electrophoretic mobility. Aust. J. biol. Sci. $28,447-455$.

Ward, C.W. (1975d). Properties and specificity of the major metalchelator-sensitive proteinase in the keratinolytic larvae of the webbing clothes moth. Biochim. Biophys. Acta $384,215-227$.

Ward, C.W. (1975e). Properties and specificity of a second metal chelator-sensitive proteinase in the keratinolytic larvae of the webbing clothes moth. Aust. J. Biol. Sci. $\underline{28}, 439-445$.

Ward, C.W. (1976). Properties of the major carboxypeptidase in the larvae of the webbing clothes moth, Tineola bisselilella. Biochim. Biophys. Acta. $\underline{429}, 564-572$.

Wharton, D.R.A.; Wharton, M.L. \& Lola, J.E. (1965). Cellulase in the cockroach, with spetial reference to periplaneta americana (L). J. Insect. Physiol. 11, 947-959. 
Wigglesworth, V.B. (1972). The principles of insect physiology. $7^{\text {th }}$ ed., Methuen \& Co Ltd, London.

Wilkinson, G.N. (1961). Statistical estimations in enzyme kinetics. Biochem. J. $\underline{80}, 324-332$.

Wolfenden, R. (1972). Analog approaches to the structure of the transition state in enzyme reactions. Acc. chem. Res. 5, $10-18$.

Wyatt, G.R. (1967). The biochemistry of sugars and polysaccharides in insects. Adv. Insect Physiol. $\underline{4}, 287-360$. 